Andrews University

Digital Commons @ Andrews University

1974

\title{
A Study of the Factors Which Have Determined Access to Secondary School Education in Trinidad \& Tobago
}

Lionel Lawrence

Andrews University

Follow this and additional works at: https://digitalcommons.andrews.edu/theses

Part of the Secondary Education Commons

\section{Recommended Citation}

Lawrence, Lionel, "A Study of the Factors Which Have Determined Access to Secondary School Education in Trinidad \& Tobago" (1974). Master's Theses. 170.

https://dx.doi.org/10.32597/theses/170

https://digitalcommons.andrews.edu/theses/170

This Thesis is brought to you for free and open access by the Graduate Research at Digital Commons @ Andrews University. It has been accepted for inclusion in Master's Theses by an authorized administrator of Digital Commons@ Andrews University. For more information, please contact repository@andrews.edu. 


\title{
… Andrews University \\ School of Graduate Studies
}

\author{
A STUDY OF THE FACTORS \\ WHICH HAVE DETERMINED ACCESS TO \\ SECONDARY SCHOOL EDUCATION \\ IN TRINIDAD \& TOBAGO
}

\begin{abstract}
A Thesis
Presented in Partial Fulfillment

of the Requirements for the Degree

Master of Arts

by
\end{abstract}

Lionel Lawrence

August 1974

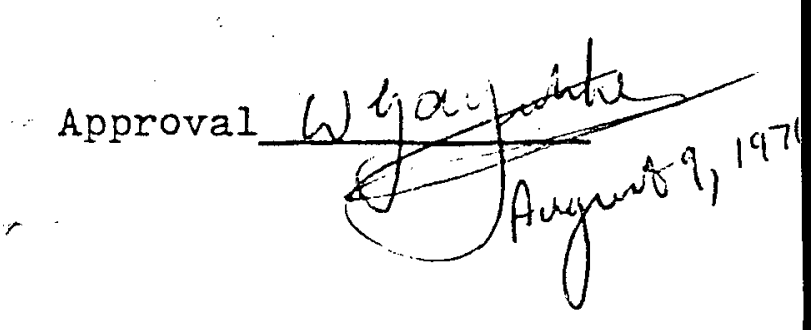




\section{ACKNOWLEDGIVENT}

The writer wishes to express his appreciation to a number of persons whose assistance and support have contributed to the preparation of this study.

To the members of the advisory committee, Dr. Wilfred G. A. Futcher, Chairman, Dr, Ruth lifurdoch, Dr. Walter Douglas, and Dr. Cecil L. Gemmell, who gave very valuable advice and guidance necessary for the proper organizing and completion of the research;

To Mr. Antony A. Latouche and Mr. Allan Murrell of Trinidad and Miss Norma Niles of Michigan who were helpful in the collecting of data;

To Mrs. Witylene Ombiga who'prepared the final typescript and Miss Shahin Ilter who edited the work; Finally, to my wife, Hyacinth, and my children, whose continual sacrifice and encouragement aided in the execution of this task.

LioneI L. Lawrence 
TABLE OF CONTENTS

ACKNOWLEDGENENTS

Page

ii

Chapter

I. INTRODUCTION . . . . . . . . . . . 1

A Brief Introduction of the Country

and its People........... 1

Statement of the Problem........ 4

Importance of the Study . . . . . . 6

Limitations of the Study. . . . . . . ?

Procedure ........... 8

Definition of Terms ........ 10

Review of Literature . . . . . . . 12

Hypothesis and Assumptions . . . . . . 62

II. HISTORICAI BACKGROUND OF TRINIDAD AND TOBAGO • 63

Spanish Rule and Settlement . . . . . 63

Immigration and Internatinnal Rivalry . . . 64

British Conquest of the Islands . . . . 66

Abolition of the Slave rrade . . . . 68

Apprenticeship and Full Freedom ..... 70

The Search for Low-cost Labor . . . . . 72

III. EDUCATIONAL PROBLEISS FACING

TRINIDAD AND TOBAGO .......... 74

The Concern for Equal Opportunity .... 74

The Need for Reorganization

of the system .......... . 77

The Need for Relevarice: . . . . . . 79 
TABLE OF CONTENTS (continued)

Chapter

Page

The Need of Professional Training of Teachers ..............

Further Assumptions . . . . . . . .

IV. SOCIAL AND ECONOMIC FACTORS AFPECTING

THE DEVEIOPMENT OF EDUCATION . . . . . . •

Composition and Structure of the population .............

Relations of Planters, Ex-slaves, Free Colored, and Immigrants. . . . .

A Legacy of Division . . . . . . . 88

Labor Deficiency . . . . . . . . 89

Alternative Supplies of Labor . . . . . 92

Depressed Conditions in Industry . . . . 93

A Persistence of Dependency . . . . . . 95

Population Growth and Iiving Conditions . . $9 ?$

Changes in Values and Aspirations ... . . 103

Summary . . . . . . . . . . 108

V. SONE ASPECTS OF THE CROWN COLONY GOVERNIENT

IN RELATION TO EDUCATION .......... 111

Origin and Structure of the Crown Colony ............ 111

Concepts of State Responsibility for
Education and Social Legislation . . . 114

Dichotomy of Plantation Development and Social Development ....... 117

Educational Prerogative in the
Crow Colony ........ 118

The Search for Constitutional Reform . . 120

Summary . . . . . . . . . 130 
TABLE OF CONTENTS (Continued)

Chapter

Page

VI. STATE AND DENCMINATIONAL PROVISION OF EDUCATION . . . . . . . . . . . . 133

Trinidad Schools Before Emancipation . . . 137

Enunciation of Plans for Popular Education .............. 138

The Contribution of the inissionary Societies to Education ......... 141

Governor McLeod's Education Plan . . . . 142

Lord Harris's Philosophy and Plans for Education . . . . . . . 144

Development of Provisions for Secondary Education . . . . . . 153

Purpose of Secondary School Provisions in the Nineteenth Century ....... 157

The Keenan Commission and the Establishment of the Dual System ...... 160

Development of Secondary Education after 1870 .................. 167

Education Commissions, 1916-1954 . . . . 177

Progress Toward Independence and the New Era of Educational Planning . . . 190

Summary . . . . . . . . . . 227

VII. GENERAI SUMUARY AND FINDINGS . . • . •. 232

Review of Fundamental Problems . . . . 232

Riajor Findings . . . . . . . . 233

VIII. CONCLUSION AND RECOMNENDATIONS ....... 241

Conclusion . . . . . . . . . . 241

Recommendations for Secondary Education. . 243 
TABIE OF CONTENTS (continued)

Page

APPENDIX A . . . . . . . . . . . . . 252 APPENDIX B... . . . . . . . . . . . . 254 APPENDIX C . . . . . . . . . . . . . 256 APPENDIX D . . . . . . . . . . . . . . 257 APPENDIX E . . . . . . . . . . . . . 258 APPENDIX F . . . . . . . . . . . 259 BIBLIOGRAPHY . . . . . . . . . . . 260

vi 


\section{IIST OF FIGURES}

Figure

Page

1. Map of Trinidad and Tobago ......... ix

2. Organization of Administration proposed

by Maurice Committee.......... 201

3. The Developing System of Education ..... 220

4. Structure of Administration of Education:

Trinidad and Tobago .......... 224 
LIST OF TABLES

Table

Page

1. Cambridge General Certificate of Education Ordinary Level Examination Results . . . . 16

2. Analysis of School Population by Age-groups . . . . . . . . . . . 20

3. Analysis of population of Trinidad at Time of Conquest, 1797 . . . . . . . . 67

4. Population of Trinidad by Classes, 1838 . . . 98

5. Vital Statistics 1950 and 1960 . . . . . . 102

6. Population Increase in Trinidad 1851-1956... . . . . . . . . 103

7. Growth of Ward Schools . . . . . . . . 148

8. Social Background of Students enrolled in Classical Schools ........... I65

9. College Exhibition Passes and Awards . . . . 194

10. Distribution of Pupils by Religion among the Various Denominational and Government Schools............. 200

11. Teachers in Schools and Colleges Classified by Qualification, December, 1958. . . . . 204 


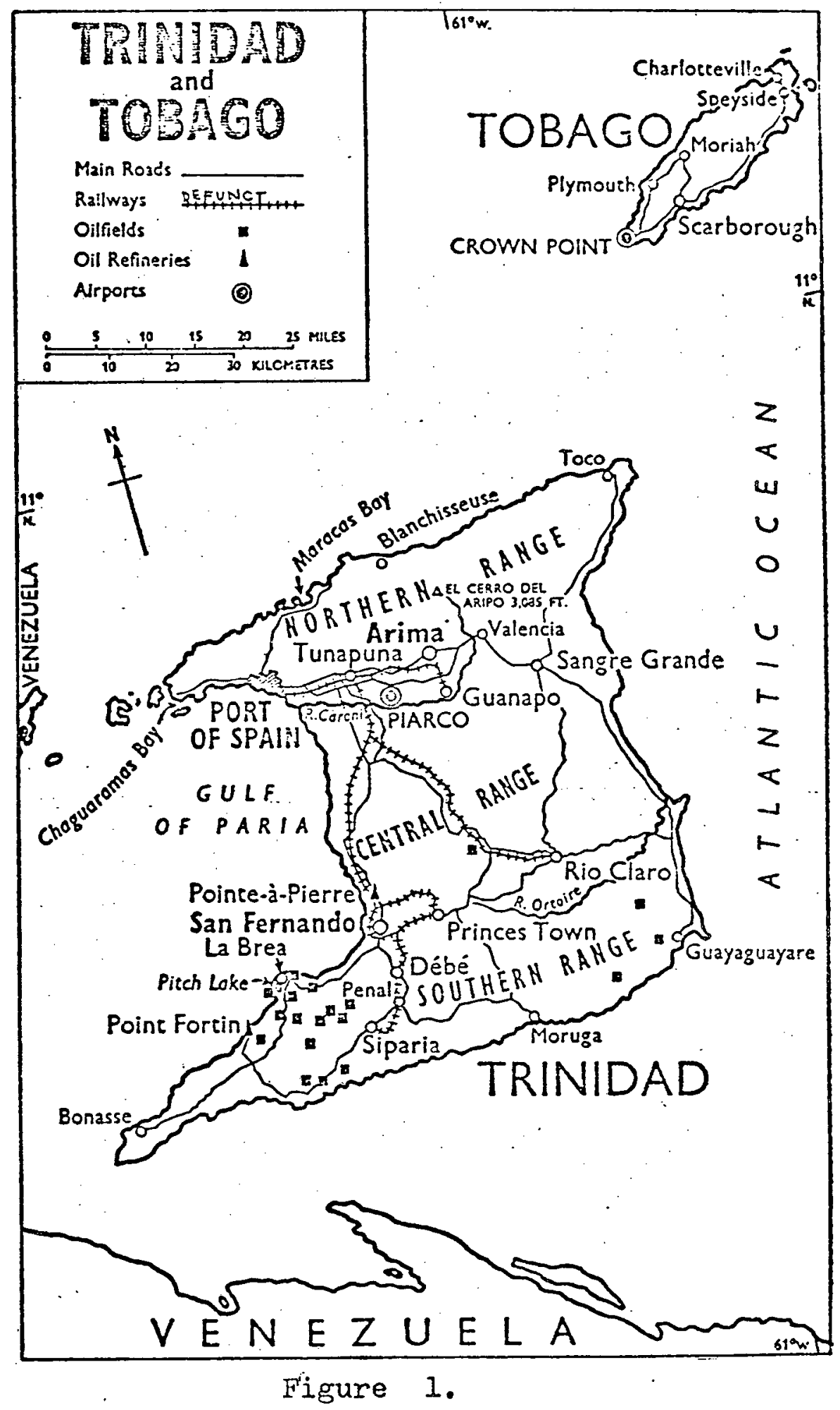


CHAPTER I

INT RODUCT ION

\section{A Brief Description of the Country and Its People}

Trinidad and Tobago, which form one political unit, became an independent nation on August 31, 1962, after more than 400 years of colonial rule. These islands are the most southerly of the archipelago that extends between Florida in the U.S.A. and the northern coast of South America.

With an area of 1864 square miles, Trinidad is, at its nearest point, only seven miles from Venezuela. Tobago has an area of 116 square miles and lies 19 miles to the northeast of Trinidad. The climate is tropical with little variation in the mean temperature from season to season. Daytime temperatures range from 70 degrees $F$ at dawn to about the mid-eighties, and the nights are usually warm. Rainfall averages from 67 inches in the west of Trinidad to about 90 inches in the east. The average in Tobago is about 86 inches. The months from June to January, with a dry spell in August, are the wet or rainy season when there are torrential showers. The occupation of the largest group of the inhabitants has been, and still continues to be, agriculture, and estates and small holdings produce mainly sugar-cane, cocoa, citrus, coffee and copra for local use and for export. There 
is also production of livestock and food crops for local use. The country has made remarkable economic growth in the post-war period, and by reason of a succession of fiveyear development plans, there has been increasing expansion. Petroleum accounts for about four-fifths of the value of exports. Exports of crude and refined petroleum include, not only local supplies, but also petroleum from nearby Venezuela. Natural gas is used as fuel and as raw material. Asphalt has long been obtained from the pitch lake at Ia Brea.

In an effort to diversify the economy, Government has passed incentive legislation to stimulate industrial development. In the post-war period, more than 100 new industries were developed.

Since the beginning of the second World War, the Government of Trinidad and Tobago has been carrying out long-term programmes of economic and social development. The relative prosperity of the country made it possible for plans to be financed from local resources and from loans, but external aid has also contributed to development.

The population of the area according to the latest official post-censual estimate is $1,020,550$ (T \& T, National Task Force on Youth, 1970, p. 10).' The population of Trinidad and Tobago is one of the most cosmopolitan in the West Indies, but a certain degree of homogeneity has been achieved. People of Negro descent account for about 45 percent of the population, East Indians about 36 percent, people of mixed 
descent 16 percent, Europeans 2 percent, and Chinese 1 percent.

The population of Tobago is predominantly of Negro stock. The Europeans are chiefly of French, English, Spanish or Portuguese origin. Among the East Indians, who are mainly agriculturists, Hindus out-number Moslems.

During the wars between England and France toward the end of the 18th century and early 19th, the possession of the island of Tobago was disputed, and it was finally ceeded to Great Britain by the Treaty of Paris in 1814. In the year 1899, it was made a ward of Trinidad, and its elementary schools, numbering 27 under denominational management, with a roll of 3,388 scholars and an average daily attendance of 2,052, were then brought under the control of the Trinidad Board of Education. The estimated population of Tobago in 1889 was between 20,000 and 21,000 (T \& T, Triennial Survey, 1955-1957, p. 9).

The CIAP Committee on Trinidad and Tobago (1970, p. 75) concluded that Trinidad and Tobago is a country where the population is highly concerned with education, but there could be much improvement from the point of view of general culture and an adequate training for the needs of the economy. Indeed, when Trinidad and Tobago became an independent nation in 1962, one of the greatest challenges that faced the government at that time was the task of building a unified system of education out of the unintegrated sectional interests influenced by factors of race, religion, and cul- 
ture.

When one considers the fact that education in Trinidad and Tobago, as in many other countries of the world, grew out of the philosophies and practices of 18 th and 19 th century Europe, there is reason to question whether the educational structure of the country did not have much obsolescence built into it.

If this is so, then, questions of highest priority in the nation's thinking must be concerned with accessibility of education, relevance of curricula to the needs and aptitudes of students, the productive value of the output of the country's institutions of learning to the aims and purposes of the society as a whole, and, more so, to the developing nation.

\section{Statement of the Problem}

In Trinidad and Tobago, about twenty-five to thirty thousand children of the ten to eleven-plus age group, in their attempt to obtain a free place in one of the government or assisted secondary schools, present themselves annually to write the Common Entrance Examination, a selective examination administered by the Ministry of Education and Culture. School places have been available, within the decade, for about 3,000 to 6,000 new entrants from the primary schools, but recently the number has increased to over 10,000 with the introduction of a two-shift system in new Junior Secondary Schools.

These efforts of the Government are to be highly 
commended, yet thousands of young aspirants to secondary education, who have an equal right to be properly educated, do not have alternative provisions made for them. The demands for secondary education clearly exceed the facilities and opportunities available at present.

Though this is a current problem of many countries of the world, the fact remains that thousands of children are left to seek some second-rate education in poorly staffed and inefficiently equipped private institutions whose purposes and goals are limited to preparation for an external examination.

Other children may turn to vocational classes without any direction or guidance as to what learning opportunities will enable them to realize the development of their potential. Still others stay on in the post-primary sections of their schools if there are sufficiently interesting pro-. grammes to hold them.

Educational Principles

The following principles are kept in view in this study, and are regarded as criteria for educational practices in Trinidad and Tobago.

1. Every child needs to receive an education which will be a preparation for life in society.

2. A child should not be left to turn to alternative provisions of schooling without direction or guidance.

3. Procedures of selection in dispensing education are undemocratic and out of harmony with modern ideas on 
education and child development.

4. Evaluation made for selection purposes lead to critical decisions about students' future development and may have a life-long result.

The investigator has been aware that a country's system of education will bear the impress of various historical and contemporary ideas and practices. He is therefore interested in discovering

1. What have been the underlying social, political, economic, and religious factors which have determined the accessibility of secondary education in Trinidad and Tobago.

2. How can the knowledge of the historical foundations of the country's educational development a) contribute to an understanding of its educational limitations, b) assist in evaluating its educational achievements, c) lead to the realization of the much desired goals of equal opportunity in education and national unity.

\section{Importance of the Study}

The understanding of the activities and problems of an educational system today requires an examination of developmental factors which have been in operation behind the scenes.

Trinidad and Tobago, like other democratic countries, desires equality of opportunity for the education of its citizens. The famous researcher in education, Kandel (1955), has remarked in this regard, ". . . every child whose talents are left undiscovered or undeveloped by the educational sys- 
tem represents a heavy loss to the community and an impoverishment of the individual life (p. 83)."

Before the achievement of independence by Trinidad and Tobago, things peculiarly Trinidad or West Indian were given scant consideration in the region. As a consequence, up to the emerging of responsible government in this territory about twenty years ago, literature which presented its educational or social development was very rare. The present study, though not an exhaustive one, may be a contribution to the growing body of relevant literature.

\section{Limitations of the Study}

The investigator wishes to note the need to limit his use of documents to those available at the Embassy of Trinidad and Tobago in Washington, D.C., the Library of Congress, The offices of the Organization of American States, the library of Michigan State University, the library of the University of Michigan, the library of Andrews University, published sources of documents, and sources which have been obtained by correspondence. He, however, draws attention to the fact of his having been born and educated in the area under study, of having been a teacher in the country for over twenty-five years, and of having previously made a study of education in Trinidad and Tobago as a requirement for the associate certificate of the College of Preceptors in England, in the subject "Educational Systems and Their Development Since 1900" (See Appendix F). 


\section{Procedure}

\section{Organization of the Study}

The study is developmental in nature, therefore, the treatment will be historical and analytic.

Chapter 2 provides a brief historical outline of the country up to the introduction of the system of indenture, when the social structure of the region was laid.

Chapter 3 presents the fundamental needs and problems of dispensing secondary school education in the developing nation of Trinidad and Tobago, and examines the relevance of the program of education at this level for the youth who are to share in the national development and decision-making processes.

Chapter 4 presents the social and economic structure of the plural society in which the educational system has been taking shape from the post-emancipation period to the recent period of independence. The attitudes of the proprietor class to intellectualism and to the social and economic levels of existence of the laboring class are displayed. Inferences are drawn with regard to the development of progressive attitudes and values in the society, and these are matched against historical evidence.

Chapter 5 analyzes the Crown Colony Government as a setting for the plantation economy, and examines its ability to promote a collective will for an educational system designed to encourage and stabilize national consciousness in a multi-cultural society. 
Chapter 6 provides an outline of the role of the religious denominations in the development of education. The concern of government administration to organize a system of education accessible to everyone is presented against religious attitudes influenced by cultural divisions.

Chapter 7 will restate the fundamental problems, assemble the major findings, and demonstrate to what extent the economic, social, religious and political environment in the country's history created conditions destined to perpetuate under-development in the absence of a common national outlook. Such an outlook is shown as desirable in order to promote equality of educational opportunity for all.

Chapter 8 will state the conclusions the investigator has deduced from the findings, and will make recommendations for future policy and further research.

\section{Sources of Data}

The sources of data will be the following:

\section{Primary Sources}

1. Administrative reports of the Department of Education (now the Ministry of Education and Culture) of Trinidad and Tobago.

2. Reports of local government committees.

3. Editorials, letters and reports of official speeches appearing in the local press.

4. Printed sources of documents on colonial administration in the West Indies. 
5. Printed sources of official documents on education in the West Indies.

6. Frinted sources of documents of the British Ministry of Education, of Acts of Parliament, and of colonial correspondence conceming Trinidad and Tobago.

\section{Secondary Sources}

Books, theses, journals, etc., that discuss, interpret, or evaluate educational, social, political and economic conditions during the period of the study, including discussions and reports of conferences.

\section{Definition of Terms}

Apprenticeship: The period of six years following the abolition of slavery in most of the British West Indian islands during which slaves and planters were to adjust to the condition of full emancipation. This period terminated prematurely in 1838.

Ascription: The ethical pattern which assigns differential treatment to things and persons in a society according to a hierarchy based on attributes possessed. In Trinidad and Tobago such attributes have been birth, race, pigmentation.

Coloured: Used in reference to hybrid descendants of slave mothers and white fathers. Also used synonymously with "negrd" by some authors.

Creole: Describes anything native to the West Indies and Spanish America and used of peoples borm in the area but of European descent. It is also thus used of western born African or mixed peoples but never of West-Indian born East Indians.

Indenture: In Trinidad, the conditions under which East Indians (called coolies) were employed by contract for work on sugar plantations.

Massa: The slave corruption of "liaster." Used by Eric Williams to symbolize the Capitalist planter. 
Particularism: Exclusive attention or devotion to one's own interests, or group, etc.

Plural Society: A society composed of such varying groups, each with its own subculture that only a few cultural symbols are shared by all. Under these circumstances there are consequentiy tendencies toward disintegration.

Primary School: A school providing schooling for the agegroup 5 to 11-plus.

Secondary School: A school providing schooling for the agegroup 12 to 14-plus at the junior level and 15 to 17 or 18 at the senior level. At the Higher or Sixth-Form level, secondary schools cater for pupils under 20 .

Society: In Trinidad and Iater Trinidad and Tobago, the collective body of inhabitants horizontally stratified by lines of class or separated by caste. Hence the description of Trinidad and Tobago as a "plural society." A more limited use is also made of the term as in "plantation society" that is the community of a plantation.

Ward School: A secular government-operated elementary school in 19 th century Trinidad, financially supported by rates from local administrative divisions known as "wards."

Intermediate School: These schools, now being phased out, received pupils from age 5 to 18 years. Throughout the infant and junior primary stages the syllabus followed was identical with that of the primary school. The senior primary or post primary sections continued five or six years beyond the junior stage.

College Exhibition: In the pre-independence, colonial period in Trinidad and Tobago, the government awarded scholarships on a competitive basis to primary school pupils to gain access to the Queen's Royal College or one of the approved secondary schools.

Eleven-Plus: The age of the recognized break between primary and secondary school in Trinidad and Tobago. At present primary school pupils about the age of eleven-plus years write the Common Entrance Examination for selection for free secondary school education.

Island Scholarship: In the period of Colonial Govemment a scholarship offered on a competitive basis to students at the Higher School Certificate level to study 
for the professions, arts or sciences at one of the universities in Great Britain.

Pupil Teacher: Especially during the colonial period, in order to supply needed teachers, post-elementary pupils of promise were allowed to teach and receive training under the direction of the headmaster of their school.

\section{Review of Iiterature}

A noted geographer and historian, Lowenthal (1972). comments on the research of Leo Pujadas on Educational development in Trinidad and Tobago. He observes that the secondary school curriculum "remains elite--academic rather than practical, focused on Europe rather than on the Caribbean, affording prestige rather than social utility (p. 120)." Emphasis on career selection was still on law, medicine, and government, and options for technical vocations were being considered indications of failure.

The unusual school enrolment in Trinidad seemed not to integrate secondary students into the society. The construction of many new schools especially in rural areas had resulted in enrolment being trebled between 1956 and 1966 , and Government awards to secondary schools increased from 230 in 1950 to 6.370 in 1966 (Ibid.). Parents tended to regard secondary education for their children as a social attainment.

However, as enrolment increased, the proportion of graduates declined. Between 1962 and 1967 passes in mathematics dropped from 83 to 35 percent, in English, from 74 to 43 percent. Fewer students gained certificates in bio- 
logy, French, English, and geography, though many more sat the examinations. The final Advanced Ievel Examination results declined also between 1956 and 1966. "The proportion of Government successes fell from 72 to 26 percent, private school from 41 to 8 percent. Of the failures, 20 percent were estimated jobless in 1969 (Ibid. p. 121)."

\section{The Demand for Secondary Education}

UNESCO figures have shown that provisions of secondary education in Trinidad and Tobago are better than those of 90 percent of the countries of the world. The fact remains, however; that in 1967, out of 41,583 children who wrote the Common Entrance Examination, 36,000 were unable to secure places in government or assisted secondary schools. Unless population growth decreases or provisions for entrance are improved, the forecast is that about 70,000 children will be seeking entrance by the end of the decade (Editorial, The Sunday Guardian, October 1, 1967). According to the Binister of Education (Pierre, 1967) at that time, in terms of schools to be built and teachers to be trained, a cost of millions of dollars was projected.

The Prime Minister, Dr. Eric Williams (1967), in his address to the National Council of the Parent-Teachers Association, gave the following warning reference to the classsical curriculum of the secondary school:

We cannot hope-and it would be foolish to entertain the idea--to rival the industrial giants, but if we do not meet the needs of the present-day world and anticipate the needs of tomorrow, we perish. Thus, the traditional emphasis on white collar jobs must go, and 
a new outlook on technical and scientific work must replace it. We cannot afford to enter a world of technology without training technologists and technicians and giving them the respect and reward that are their due (p. 17 ).

\section{Distortion of Education}

The Director of Education (1946), in his official

report stated:

There is only one government secondary school, the Queen's Royal College, a day school catering mainly for Port of Spain. Government relies on a number of denominational secondary schools. There are 4.775 secondary pupils in the island and 94,343 primary. Fees are charged and schools are heavily subsidized by government. It is highly doubtful that secondary places are awarded to those most deserving of secondary education at public expense. In the quest for certificates, schools must not be deflected from the aim of providing all-round education of the complete man ( $p .3)$.

The report of 1946 questioned the validity of the predictive ability of the college exhibition examination which was open to pupils under twelve years of age. On the results of the examination 52 places were awarded. This was the only chance for the majority of thousands of children of securing a secondary education, and competition was keen. The examination was considered far from satisfactory, as only those who had special coaching could hope for success. In regard to these practices, the 1946 report stated:

This leads to many abuses. Candidates are subjected to undue cramming and strain at a tender age; some teachers tend to neglect the ordinary pupils in favour of those who can pay for extra lessons, and candidates concentrate only on the subject of examination to the detriment of broad educational foundations. Many successful candidates in the past have faded completely away in the secondary school for lack of sound grounding (Ibid.). 
"What are we educating for?" the Draft Plan (1968-

1983) queries,

We are supposed to produce citizens who are intellectually, morally and emotionally fitted to respond adequately and productively to the varied challenges of a life in a multi-racial developing country and to the changes which are being brought about rapidly in the economic foundations of civilization, particularly the challenges of Science and Technology (p. 5).

The irrelevance of the field of knowledge in which most students were being prepared for their society can be deduced from the statistics of the examination results, shown in Table 1 , of the Ordinary Level Cambridge General Certificate of Education in 1964 and 1965. In the colonial period, the much coveted island scholarships for study in English universities were based on the results of the Higher Certificate Examination. The irrelevance of this syllabus was pointed out by Williams (1942):

(1) English Political History, (2) a special period of English Political History, (3) European History,

(4) Greek History, (5) English Colonial History, (6) English Economic History, (7) Latin textbooks, translation, composition, and Roman History, (8) French textbooks, translation, and composition, (9) Spanish textbooks, translation and composition, (10) two plays of Shakespeare, (II) a play of Chaucer. (2) two papers on a special period of English Literature, one on specially assigned books, the other general. English examinations set by English examiners in England is the rule. In one notorious instance an essay was assigned on "A day in winter" to students to whom winter was only "hiemps" or "hiver" or "invierno" (p. 76). 
Cambridge General Certificate of Education, Ordinary Level

EXAMINATION RESULTS

Summer 1964, 1965

Subject

English Ianguage

English Iiterature

Bible Knowledge

British and European History, 1066-1688

British and European History, 1485-1815

British and European History, 1688-1920

History of the British Empire and Commonwealth West Indian History

Geography

Latin

Greek

French

German

Spanish

Mathematics A

Mathematics $B$

Additional Mathematics

General Science

Agricultural Science

Fhysics

Chemistry

Chemistry Alt. N

Biology

Fhysics-with-Chemistry

Art

Music

Woodwork

Metalwork

Needlework and Dressmaking
Trinidad, 1964

Number of Passes candidates $(\%)$

$\begin{array}{rc}5.636 & 23.3 \\ 3.896 & 24.4 \\ 3.702 & 32.0 \\ 263 & 32.3 \\ 305 & 44.9 \\ 75 & 41.3 \\ 504 & 44.8 \\ 1.045 & 41.8 \\ 2.518 & 32.7 \\ 990 & 39.9 \\ 6 & 6 / 6 \\ 1.942 & 27.2 \\ & \\ 2.974 & 21.1 \\ 3.303 & 33.8 \\ 81 & 27.2 \\ 242 & 48.8 \\ 181 & 44.2 \\ 12 & 3 \% 12 \\ 484 & 42.4 \\ 828 & 56.1\end{array}$

$\begin{array}{rc}1.010 & 35.3 \\ 36 & 16 / 36 \\ 581 & 40.4 \\ 3 & 1 / 3 \\ 18 & 1 / 18 \\ 0 & -14 \\ 204 & 14.2\end{array}$

Trinidad, 1965

Number of Passes candidates $(\%)$

$\begin{array}{rr}7.875 & 23.9 \\ 5.238 & 28.9 \\ 4.717 & 38.0 \\ 324 & 30.9 \\ 203 & 33.0 \\ 47 & 14 / 47 \\ 852 & 35.4 \\ 1.782 & 39.6 \\ 3.566 & 27.2 \\ 1.140 & 42.0 \\ 6 & 6 / 6 \\ 2.239 & 27.5 \\ 1 & 1 / 1 \\ 3.574 & 26.9 \\ 4.244 & 40.5 \\ 116 & 26.7 \\ 370 & 56.5 \\ 161 & 41.6 \\ 9 & 3 / 9 \\ 583 & 44.4 \\ & \\ 1.082 & 62.3 \\ 1.408 & 35.3 \\ 7 & 0 / 7 \\ 776 & 37.0 \\ 7 & 5 / 7 \\ 112 & 15.2 \\ 2 & 0 / 2 \\ 164 & 25.6\end{array}$


Ordinary Level Results, Trinidad, Continued

\section{Subject}

Cookery

Geometrical and Niechanical Drawing

Commerce

Principles of Accounts

Health Science

107th and 108th Annual Report of the Cambridge Local Examinations Syndicate.

\section{Source:}

Trinidad, 1965

Trinidad, 1964

Number of Fasses candidates $(\%)$

$\begin{array}{rc}241 & 49.4 \\ 2 & 0 \% 2 \\ 135 & 45.2 \\ 19 & 0 \% 19 \\ 2.463 & 21.0\end{array}$

9.4

45.2

$0 / 19$

2,463
Passes candidates $(\%)$

$\begin{array}{rc}327 & 42.8 \\ 28 & 6 / 28 \\ 238 & 14.3 \\ 60 & 1 / 60 \\ 3.686 & 16.6\end{array}$

Cambriage Local Examinations syndicate. 
The First Conference of Secondary School Heads in the British Caribbean, 1955. found that the external examinations did not make sufficient allowance for the wide range of ability among the children in the schools, the syllabuses being especially unsuitable to the less able group. The examiners in England failed to show a clear understanding of what was appropriate to schools in the Caribbean, and a link through committees in each country was considered to be at best a poor substitute for having examinations set by the people with an intimate knowledge of local conditions.

Pressing all children through the same mill, without resources for enrichment, resulted in the brighter pupils being held back, the average subjected to a narrow curriculum, and the slower learners often leaving school with their education incomplete and themselves marred by a sense of failure and frustration (D'Aeth, 1956, p. 28).

Adverse effects of competitive and selective examinations The first Government operated secondary school, the Queen's Collegiate, was inaugurated in 1859 and replaced by the Royal College of Trinidad to which denominational secondary schools were affiliated, enabling them to receive grantsin-aid and present candidates for the public examinations. Three pupils were originally admitted free from primary schools on passing the difficult College Exhibition Examination.

The social structure of the country permitted "A very small and exclusive percentage of the population (Gordon, 
1963, p.242)," to reçeive secondary education. Fees were charged which were prohibitive to all but whites and fairskinned coloureds. Noreover the stipulation of legitimacy of birth as a prerequisite to entrance into the secondary school excluded more of the negroes than of any other group (p. 239).

External examinations do not usually keep pace with the progress of educational ideas and thus they hamper the progress of education. Teachers tend to truncate the regular elementary curriculum in their desire to prepare students carefully for the demands of the entrance examination syllabus. The lack of reality in selecting by entrance examinations is seen when one considers the differences in the quality of staff and equipment of schools and the individual differences and aptitudes of children (See Appendix C).

\section{Problems Facing Secondary Education}

Education planners in Trinidad and Tobago "have concentrated attention on the very crucial issue facing developing countries, namely, how to provide quality education in sufficient quantity as to meet the demand and the need at sufficiently low cost as to be financed by a poor society (Draft Plan, 1968, p. 5).

Many children who have not been selected for a secondary school place on the basis of the eleven-plus examination have been following the traditional post-primary three-year cycle for the 12 to 15 years age group, which contributed little to their overall education. Since this 
cycle has been found to be wasteful, it is being replaced with a junior secondary cycle integrated with a senior secondary cycle calculated to provide for the students' overall education, with more emphasis on vocational education.

The following data, in Table 2, show the percentage of children in each age group actually receiving education in $1966:$

TABIE 2

Analysis of School Population by Age Groups, 1966

\begin{tabular}{c|c|c|c}
\hline \hline Age Group & $\begin{array}{c}\text { Percentage in } \\
\text { primary school }\end{array}$ & $\begin{array}{c}\text { Percentage in } \\
\text { secondary school }\end{array}$ & $\begin{array}{c}\text { Percentage in } \\
\text { all schools }\end{array}$ \\
\hline 12 & 74 & 13 & 87 \\
13 & 50 & 16 & 66 \\
14 & 33 & 17 & 50 \\
15 & 2 & 14 & 16 \\
16 & - & 12 & 12 \\
17 & - & 8 & 8 \\
\hline
\end{tabular}

Source: CIAP Sub-committee on Trinidad \& Tobago, 1967. Domestic efforts and needs for external financing for the development of Trinidad and Tobago. -IV-13. Pan American Union, Washington, D.C.

From these data it is shown that most children terminated their education at age 14 , and few went to secondary school.

Roberts' study (1967, pp. 113-126) on school enrolment shows that of a 10,000 male cohort in the country, 9,878 attended school in $1960,3,428$ passed on to secondary 
school, with an estimated 550 achieving success at the level of the school certificate or its equivalent. The figures for the female cohort are parallel with a little more than one quarter of the secondary school graduates qualifying for university, as against a little less than half of the males.

\section{Early Consideration of Popular Education}

Iord Harris assumed the Governorship of Trinidad in 1846, and soon introduced his system of secular primary schools or ward schools. This proved to be abortive because of religious opposition and other factors. However, with regard to secondary education, his intention was that his plan of ward schools (Williams, 1962).

$\therefore$. would be rendered complete by the establishment of a college, to which those scholars who might be found fit might be passed on, so that in fact every encouragement would be given to all, however humble their birth, to place themselves in such a position as their talents and their industry would show them capable of supporting (p. 203).

The Triennial Survey 1955-1957 (1959), in its review in outline of education in the country, presents the recommendations for the Educational Folicy and Development Programme, Council Paper No. 27 of 1946 of the Department of Education in which is included:

Provision of free education for all children between the ages of 5 and 12 at primary level and for those from 12 to 15 years at Central Schools or Post-primary classes in primary schools, the equality of opportunity to be achieved by scholarships to secondary, technical, or agricultural schools ... (p. 16).

Following close upon the civil disturbances which 
occurred in Trinidad in 1937-1938, the West India Royal Commission, under the chairmanship of the Right Honorable Lord Moyne, D.S.O., arrived in the colony in February, 1939 and remained more than a month pursuing its enquiries. After considering the social conditions, referred to later in this investigation, the Commission made some recommendations concerning education in Trinidad and Tobago. These are summarized in the Triennial Survey of the Department of Education of Trinidad and Tobago. Section 40, par. (i) recommends:

"Restriction of the primary school age from six to twelve, conditional on the establishment of Junior Secondary Schools for ages twelve to fifteen... (p. 13)."

Gordon, (1963b), quotes Sir P. J. Keenan, who examined the condition of education in Trinidad in 1869:

The resolution--passed in September, 1857--of the Board of Council, in justification of the foundation of a collegiate school, professes that the object in view was "to place within the reach of the youth of the colony the opportunity of obtaining a classical education at a moderate charge." . . "The youth of the colony" could never have had reference simply to the youth of the wealthy class of the colony; and in the case of a poor man who is the father of a youth desirous of a classical education, the term "moderate charge" can assuredly not apply to a fee of 15 per annum. In such a case the term "moderate" is certainly misapplied. But even to the well-to-do people of the colony such a fee must be looked upon as high. Foor and rich know that besides paying the moderate fee they are contributing in the general taxation to the maintenance of the school (p. 13).

Keenan's further appraisal of secondary education in Trinidad was limited to the relative contributions of the Queen's Collegiate School and the College of the Immaculate Conception, or St. Mary's which had for the past six years 
replaced St. George's College. The former was a secular government college for 68 boys, taught by English graduates of Oxford and Cambridge. The curriculum was that of the newest public schools, and the measuring instrument was the examination of the Cambridge Syndicate. Trinidad Island Scholarships were available annually for boys to proceed to English universities if they could compete for them at the Cambridge Senior examination level (Gordon, 1968, p. 26).

That the two secondary schools were providing education for a small elite is evident from Keenan's remarks:

The first thing likely to strike a person who has considered these reports is the strangeness of the fact that whilst the white population, which is only between 5,000 and 6,000 furnishes 142 pupils to collegiate establishments, the coloured population, which, exclusive of the Coolies, numbers from 60,000 to 70,000 , furnishes only 37 pupils (Williams, 1962, p. 202).

The social selection of the pupils is also seen from the fact that the 184 boys receiving secondary education represented only the homes of civil servants, clergymen, planters and proprietors, merchants and professional men. The working class were conspicuously absent. Even as late as 1889, the principal of Queen's Royal College could report on the limited admission to secondary education:

The population of Trinidad approaches 200,000 in number, but the demand for secondary education is not large in proportion because the educated classes, those who possess more than simple elementary knowledge, form a much smaller minority than in England, and the wealthier members of them prefer to send their sons to Europe.

What is done, therefore, for secondary education in this Colony amounts to this, that in its chief town only professional men, Government officers, 
ministers of religion and business men are able to get for their sons a fairly good grammar school education at a comparatively cheap rate (Gordon, 1963a, p. 244).

Williams (1969, pp. 2l-23) regards these depressed social conditions as partly attributable to the overriding British interest in maintaining an economy for the colony based on sugar supported by indentured labor with the concommitant social malaise resulting from the poor health, the ignorance and low cultural level of the laborers which resulted in a colossal expenditure. Of a total expenditure of just under a million pounds in the colony in 1911, while $\$ 62,000$ was spent on education, expenditure resulting from indenture, (immigration, police, jails, hospitals etc.) amounted to over $\$ 200,000$. Primary education was not yet free, Secondary education was urban and ultra-conservative with a curriculum that tended toward Anglicization of the colony, while the predominance of the English influence subordinated all things culturally Trinidadian (Williams, 1969, pp. 21-23).

The conflict of vested interest and popular education is brought out by Rubin and Zavalloni (1969):

The British public education movement had received its impetus in the early nineteenth century. However, equivocal ideological and economic considerations were involved in the spread of education to plantation societies, both under slavery and later under the indenture system. . . The spread of education would have been a threat to both the ideological and the economic underpinnings of the institution of slavery. After Emancipation it became clear that extensive education was equally incompatible with the indenture system. The plantation, whether under slavery or indenture, required a large, stable, and cheap labor force. Education of 
the workmen and their children was not consonant with the fundamental requirement (pp. 34-35).

Governor Keathe's request to the Secretary of State for the establishment of a secular secondary school was obviously intended to counter the French-Creole Catholic influence in the British Colony. Gordon (1963a):

- . the Roman Catholic college is at present the only establishment which affords classical and general instruction to the children of parents in the upper ranks of life. . . Irrespectively of the sectarian tone of this college which is very strong and decided, a result of its being completely under the direction of Archbishop Spaccapietra, who resides in it, is that there is every prospect of its entirely losing its English character (p. 75).

Ethnic and class factors within the plantation economy were complicated by the status of the East Indian indentured laborers and their children. Williams (1962) quotes the Keenan report:

I cannot call to mind any other case of a people, who having voluntarily come to a strange land which they enriched by their labor, were morally and intellectually so completely neglected as the Coolies have been during the past twentyfour years ( $p .212$ ).

Wardle (1970), in discussing the provision of secondary education in England, indicates that ever since 1902 there has been a steadily increasing tension between elitist and egalitarian interpretation of the concept of secondary education.

The establishment of secondary education along egalitarian lines will raise important questions about the content of the secondary school curriculum. Whatever the virtues of the grammar school are, it was not intended for the education of the whole population, and it cannot be said that the secondary modern school has been particularly successful in finding an alternative course of study (p.138). 


\section{Criticisms of the College Exhibition}

The College Exhibition was criticized as demanding a truncated curriculum. The whole of the primary school system was infected for the sake of giving grammar school education to one percent of the 11 to 12-year age group. The rest of the school was neglected. Many of the examination questions were considered as beyond the level of 11year-olds. There was consequently special tutoring during and out of school hours from early morm until late afternoon for younger and younger children many of whom failed year after year. Some children were prepared for the examination but, in order to protect the prestige of their school, were not allowed to sit because they had failed a preliminary test.

\section{Free Secondary School Places Increased}

The Trinidad ordinance of 1870 provided four exhibition places for pupils in the whole country to enter the Royal College of Trinidad. This provision was later extended to include pupils from denominational schools affiliated to the Royal College. The number of free places was increased to 8 in 1918, to 16 in 1942, to 52 in 1948, and to 401 in 1957 (T \& T, Triennial Survey, 1959, pp. 14, 20, 32, 34; T \& T, Historical Development of Education, 1962, p. 17). Through special Government assistance to denominational schools for extensions and renovations of buildings, more than 6.000 children were awarded free scholarships in 1966 (Gomes, 1972, p. 69). 


\section{Opposition from Principals \\ of Assisted Schools}

Assisted denominational schools had been for decades the purveyors of elementary and secondary education in the country. The continual increase in the number of exhibitions, though a great boon to some of the poorer parents who were unable to pay for the education of their children, was disconcerting to a number of the heads of assisted schools, who foresaw the possibility of all their school places being filled in future by Government free scholars, whom they regarded as being below standard academically; for the exhibition not only admitted a child, but also gave a choice of school of the prestigious type, from which some of the ordinary fee-paying pupils of middle or upper-class vintage might be excluded by pressure of government applicants.

\section{The Maurice Committee}

This recalcitrant attitude on the part of the principals of assisted schools brought forcibly to view the fact that the educational system was inadequate to meet the quantitative needs of a country on the threshold of independence, and about to enter into a twentieth century world being constantly transformed by technological and scientific advance; and even less adequate to give the necessary leadership and direction in social change. Made aware of these weaknesses, the government, in July 1957, appointed the Committee on general Education, consisting of 22 persons and comprising members of the government, the clergy and outstanding educators under the chairmanship of Mr. J. Hamilton Naurice, with 
the approval of the governor in council. The terms of reference of the committee were (1960):

To consider the operation of the educational system of the country and make recommendations on future policy related to curriculum, the improvement of academic and other standards and the integration of the diverse elements which comprise our population ( $p .3$ ).

The committee objected to the recalcitrant attitude of the secondary school heads and recommended:

(i) The abolishing of the College Exhibition and its replacement by a common entrance examination for fee-paying and non fee-paying pupils

(ii) The appointing of an examination body and the confidential handling of all examination matters

(iii) Two chances only per pupil at the examination and the discontinuance of the practice of holding pupils 3 and 4 years in special examination classes

(iv) The closer linking of primary and secondary education so as to form one continuum

(v) The diversification of secondary education to cater for the different aptitudes of pupils

(vi) The provision of more formal technical education of all kinds (Ibid., pp. 177-196; Pierre, 1968, p. 1).

\section{Frimary - Secondary Bridge Established}

Prior to this, elementary education in the country was organized in the framework of 5 to 15 years, all age schools, but a change was made on the implementation of the British Education Act of 1944 (Great Britain, H.M.S.0., 1945): "The statutory system of public education shall be organized in three progressive stages known as Primary, Secondary and Further Education (p. 4)." 
Primary education was officially regarded in Britain from 1918 as terminating at 11 plus, though (Curtis \& Boultwood, 1966) "it is common knowledge that the age of 11 plus was adopted when the school leaving age was 14 years, so that the pupil might have a 3-year secondary school course (p.206)."

\section{Inequality of Educational Opportunity}

Before the Trinidad and Tobago government initiated its 5-year planning in 1956, secondary education was given mainly in 2 state schools, 12 assisted denominational schools and $a$ number of private or independent schools. These were all fee-paying schools. Entrance to these schools was, in the case of the state and assisted schools, either (i) free, on the basis of passing the College Exhibition Examination, or (ii) the payment of term fees after passing a particular school's entrance examination. Private schools accepted feepaying pupils or others who had received scholarships from private organizations.

\section{Equality of Educational Opportunity Attempted}

In 1960, on the eve of independence, government committed itself to granting free secondary education in all state and assisted secondary schools. The Ministry of Education and Culture gave careful consideration to this and, with the cooperation of the denominational boards and assisted schools, a Common Entrance Examination was introduced, through which pupils would be selected for secondary education. 
system by means of which entrance to secondary school is based on the results of a common examination--was inherited from Great Britain during the period of the country's colonial history (Ibid., pp. 303, 304).

\section{The Common Entrance Examination}

The first Common Entrance Examination was held in 1961, when standardized objective tests in verbal ability, arithmetic and English, constructed by the National Foundation for Educational Research in England and Wales, were administered. These tests, although serving a very useful function, were subjected to some severe criticisms from the staff of secondary schools, who were very seriously concerned with the low level of attainment of pupils admitted. Since 1964 a new battery of tests has been used for the examination. The tests are intended to assess those abilities that are known to be essential for successful secondary school work, and thus to identify the students having the highest probability of coping with secondary school requirements (See Appendix A).

\section{Criticism from the Public}

Several pertinent criticisms have come from interested and knowledgeable members of the public and the press to the effect that the Common Entrance Examination was using as models, evaluative methods that were already regarded as unorthodox in Britain. Reference is made to the Report of the Consultative Committee on the Primary School of the 
Board of Education, 1931:

It should be a cardinal principle that the examination should follow the curriculum and not determine it. . . . The conception of the primary school and the curriculum must not be falsified or distorted by any form of school test whether external or internal. The technique of examination must accordingly be so developed that it keeps abreast of that steady process of humanizing and broadening of the course of study in the primary school which is the theme of this report (p. 105).

The Consultative Committee, however, continues to say that "Nothing is more reliable than the personal judgment of observant and impartial teachers who have been in contact with their pupils over a period of years; even though in a comparative estimate of pupils drawn from a large number of schools, this personal judgment, as we have already implied, must be related to some general standard of ability and attainment (Ibid., pp. 103, 104)."

An editorial in the local press quotes a headmaster as deploring the fact that the purpose of primary education was being forgotten and distorted as all energies are directed towards one end--cramming children for the Common Entrance Examination (Trinidad Guardian, March 5, 1967):

The syllabus is neglected and children are taught the techniques of passing an examination while it does not prepare them for what comes after the examination. - . Parents have always regarded secondary education as a forward step in social achievement. The tendency has grown considerably more widespread, going from the middle class to the working class. . . It is highly laudable that parents would want the best for their children, but unfortunately, the children are being harassed with threats and promises. . . Under pressure, children of the greatest intelligence collapse (p. 8).

The question of privilege was seen to be still a 
determining factor in selection for school places, since secondary schools were insufficient in number and unevenly distributed over the country. The late Dr. Andrew Camacho of the Ministry of Education and Culture indicated in a public address (July 27, 1967) that the three primary factors of (1) examination marks, (2) choice of school by parents, and (3) the locality of the student were factors which decided the gaining of a place.

The Norwood Report of 1941 stated (Williams, 1968), "The time is past when such guidance and direction as teachers need can be given by means of an external examination (p. 54)."

\section{International Cooperation}

The recommendations of the UNESCO Hission reported in August, 1964 were (Pierre, 1968),

(i) The integration of the school system to secure freedom of movement vertically and laterally, and re-entry at various levels by establishment of continuation and up-grading classes

(ii) The establishment of a 3-year Junior Secondary School course for the age group 12 - 14 years into which all llt children would be channelled

(iii) The establishment, at the Junior Secondary level, of a daily Shift System, so as to provide sufficient accommodation for all children at eleven plus

(iv) The establishment of a National Testing Service involving educational guidance and research, to be substituted for the Common Entrance Examination

(v) The establishment of Senior Comprehensive Schools, strategically located, for which the selection of pupils will be made at age $14+$ with a choice of technical as well as academic courses on the basis 
of the recommendations of the National Testing Service (p. 1).

The Third Five-Year Plan introduces Junior Secondary Schools intended to cater for the age group 12-14t. Approximately 31,000 places are to be provided in 16 new schools on the double shift system. Some of the existing Secondary and Intermediate Schools are to be converted to accommodate a further 8,400 children approximately on a single shift system, making a total of 39,400 places at the junior secondary level by 1973. This will give an intake of 3,000 per year into Junior Secondary schools along with 3.400 into other secondary schools through the Common Entrance Examination (Planning Commission, Five-Year Plan 1969-1973, pp. 338, 339).

\section{Social and Economic Factors}

The attitude of planters to the free laborers in the post-emancipation period is further demonstrated in their attempts to practically nullify the effects of freedom. They had agreed at their meeting to eradicate squatting and had obtained the compliance of Lord Grey (Matheison, 1963), the Secretary of State who had advised a speedy passing of a law for ejection of squatters. The Crown land should be priced very high and the proceeds used to clear land for village lots which should also be sold at a high price so that the new free holders should "look to labour on neighbouring estates as their main dependence." Grey further indicated that peasants should be placed "in circumstances in which a greater amount of labour than at present should be required to 
supply their wants (pp. 87, 88)."

The humanitarian, Lord Harris, disproved such a policy. He did not believe that drudgery of labour improves the lower orders either morally or physically. Crown lands he felt should be sold cheaply, at least 5 shillings an acre so that the laborer might be saved from being too dependent on those "who might not weigh his interest with an impartial hand (Ibid.)."

High wages, allowances, free housing and provision gardens on the one hand, and the need of the laborers for money on the other did not give the planters the kind of labour they considered essential to keep up their production and to meet in the British market the competition of slave sugar from other countries (Wood, 1968). "They wanted a regular and docile force with a low turnover but instead, they had mobile laborers who would not be bound by any contract and who would leave to seek better conditions if they pleased (p. 54)."

The planters' attitude in 1926 is further given by Williams. Until the beginning of the Canadian Mission work for Indians in the $1860^{\prime} \mathrm{s}$ the education of their children was completely neglected.

The attitude of planters to education under the Crown Colony System is further illustrated in the evidence of two planters before a select committee of the legislative Council appointed in 1926 to enquire into the restriction of hours of labor in the colonies. The planters took the utilitarian 
view of education for field laborers. One planter was of the opinion that if the children were educated they would not want to be laborers. The children might be given some education in the way of reading and writing for about 3 hours a day, and the bright ones may be allowed to win scholarships. Education of the whole mass would ruin the country. The other was of the opinion that as long as Trinidad was an agricultural country the children would not need education as it would be of no use to them if they had it. Thus as Williams (1962) argues, "the Crown Colony needed only sugar workers. It did not need citizens (p. 215)." It was clear that education for intelligent citizenship was not compatible with a plantation economy. Williams (1961) in "Iiassa Day Done" indicates that the planters' economic programme represented the artificial structure of West Indian Society, and a powerful Royal Commission was sent From Britain to the West Indies in 1897. It condemned the emphasis placed on a single crop peculiarly vulnerable in the markets of the world, attacked the planters' insistence on a plantation economy and it projected a dismal future in the West Indies unless there was economic development involving the settlement of labourers on the land as peasant owners.

Williams further states that the report of Royal Commissions could easily be ignored in those days. These social and economic conditions were still in existence in 1930 when another Royal Commission repeated the condemnation in almost 
identical language. The planters' long economic domination of the West Indian islands reduced the population whether free or unfree "to the drudgery of the simplest and most unedifying operations, almost unfitting them totally for any intelligent agricultural activity, giving them a profound and lmost permanent distaste for agricultural endeavours (Ibid., p. 4)."

Before the Royal Commission of the Franchise in 1889, Mr. Lochmere Guppy, an English settler in Trinidad who had become Mayor of San Fernando, related a conversation between himself and a planter when he sought to obtain better housing conditions for Indian immigrants: "The people ought to be in the field all day. I do not build cottages for idlers." The Major suggested the possibility of sickness, children or pregnant women. The planter's reply was, "Oh my dear Guppy, what do you talk to me about lying-in and nursing women. I only want working hands." "Then you will never have a settled population," said the planter. "I want two years of good crops and good prices and then I will sell my estates and go to Iive in Europe (Ibid., p. 8)."

Williams tersely concluded in March, 1961 on the eve of Independence of Trinidad and Tobago in 1961: "llassa was determined not to educate his society. Wassa was quite right. To educate was to emancipate (Ibid., p. 12)."

Guppy, Williams affirms, was confirmed in his opinion that the sugar interest had not saved the colony but had ruined it. This was an obvious example of laissez faire 
policy by a planter-dominated Crown Colony legislature responsible not to the people of Trinidad but to the Secretary of State for the colonies.

Such particularistic dominance, Guppy states, was evidenced by the absence of beneficial control in the general interest of the island by the construction of a railway system destined to be of benefit only to a few sugar planters, to the total neglect of other productive areas of the island (Williams, 1962, pp. 115, 116).

Sewell (Comitas \& Lowenthal, 1972), in reference to West Indian planters states, "They never cared for the comfort or happiness of their tenants, or sought to inspire them with confidence and contentment. They made no effort to elevate labor above the degraded level at which slavery left it. . (

He further states that "the planter was bred to the belief that his business could only be conducted with serf labor, and he clung to the fallacy long after serf labor had been legally abolished (p. 143)."

Dr. deBoissiere, an opponent of the system of indenture protested in 1890 against the costly system which was financed by taxpayers when priority should have been given to natural and free immigration from nearby Barbados (Williams, 1962): "History will pen a terrible indictment of neglect against the administration of the last 30 years. . . (p. 116)," deBoissiere is quoted as saying. of the several critics who have written concerning 
the failure to establish a stable society in the post-emancipation period, the most authentic is perhaps the exceptionally farsighted governor, Lord Harris, who stated in a dispatch from Trinidad in 1848 (Burn, 1937):

One of the many errors which have been committed since the granting of apprenticeship is the little attention paid to nay legislation having for its end the formation of a society on true, sound and lasting principles. That such an object could have been attained at once was and is not to be expected, but undoubtedly, had proper methods been adopted, much greater progress might have been made. As the question now stands a race has been freed but a society has not been formed (p. 370).

\section{Britain's change of policy toward the West Indies}

\section{Williams (1962) points out that:}

In 1846 the British government abandoned its traditional policy of the Exclusive and protection for colonial products in the British Market. The industrial revolution in Britain was then in its full swing and British goods, cheapest and best in the world at the time, required no protection in the small and limited colonial markets. Britain wanted to buy sugar from anywhere in the world in order to sell British goods to those sugar countries outside of the West Indies. Therefore Britain, as part of its general policy of free trade, abandoned the preferential sugar duties which had protected the sugar colonies. The equalization of the duties was to take effect six years later in 1852 (p. 101).

Williams further indicates that the permission for immigration was Britain's compensation for the abandonment of protection of West Indian sugar. Immigration was to be supported partly "by the taxes paid by the very ex-slaves with whom the Indians were to compete (Ibid.)."

\section{Social Structure}

The reaction to the suggestion to train humbler classes 
of the youth to be overseers at the Woodbrook Model School illuminates the social structure of Trinidad's plural society. The Inspector of Schools in his report made reference to the attitude of the community to

. . an over-educating of the minds of persons in the humbler walks of life, whose career, it is thought, had better be confined to mechanical or manual occupations. . . (Quoted in Gordon, 1963, p. 66).

He saw a distinction always being maintained in the social scale by means of the superior classical education afforded at Queen's Collegiate School. But for this institution, he thought it very likely that "the toe of the peasant coming so near the heel of the courtier as to gal his kibe (Ibid., p. 67)."

The eonomist Beckford (1972, pp. 207, 208), generalizing on education in plantation economies, says that education is rationed among groups within the society. Secondary schooling is selective, and social status is a variable in admission. Available education is for the most part irrelevant to the environment and to the needs of a dynamic society, being weighted to the supply of administrative skills with no technical and managerial skills. Medicine and law, which are status giving occupations, are the only two professions that win favor in the process (Ibid.).

The social and economic under-development in Trinidad and Tobago, as in other colonies which have been dominated at one time or another by a plantation system, are traceable to three factors which have enunciated by this author: 
(1) The plantation system denies the majority of the people of plantation societies a real stake in their country.

(2) The system creates a legacy of dependence because the locus of decision making concerning fundamental economic issues resides outside the plantation society, so that a chronic dependency syndrome is characteristic of the whole population.

(3) The majority of the people are not sufficiently motivated toward the development effort because of the first two considerations (Ibid., p. 215).

The author expresses the view that no meaningful

change can take place without measures to correct these three basic defficiencies (Ibid.) He also supports the assumption that an inadequate social structure is one of the contributory factors to inequality of educational opportunity when he points out that among the "concrete social requirements of development is an educational system designed to promote national consciousness (Ibid., p. 203).

Beckford also proposes the thesis that "the low skill content involved in plantation work does not generate over time a diffusion of skills among the population," and this produces "under-development biases." Economic development in any country, he holds must be founded on a compatible social environment, and argues that economic development requires a "highly motivated population with progress-oriented values directed to the development effort, and with social institutions that provide the necessary incentives and rewards (Ibid.)." 
The Roles of the Religious Denominations and the British Government in Education

The abolition of slavery in Trinidad undoubtedly entailed new social arrangements. The British Government, therefore, provided in the Emancipation Act for the education of the youth of the Negro population by its Negro Education Grant (Gordon, 1963, p. 20).

The problems involved in implementation of the program of Negro education are presented by Gordon (Sterling Report, 1835):

(1) Iegislatures, dominated by sugar interests, who gave no indication of being particularly sympathetic towards education for the children of exslaves whom they wished to keep on their estates as low-paid laborers.

(2) The uncertainty of the resources of the religious denominations to provide adequate education.

(3) Education was largely in the hands of Protestant missions in a predominantly Catholic population (Caribbean Quarterly, Vol. 8, No. 3, Sept. 1962, p. 149).

The British Government imagined that a compulsory system of education would develop from the implementation of the Negro Grant (Ibid.) One of the principal concerns of Crown Colony government was the heterogeneous nature and foreign elements of the population, as well as the variety of languages spoken. Governor Mcleod (Augier et al., 1962, pp. 165. 166) recognized the need for the development of a common system of education in his communication to the Secretary of State in which he stressed the fact that some two-thirds of the natives still spoke exclusively Spanish 
or French and that it was absolutely necessary that people claiming to be British subjects should be able to read the laws by which they were governed.

One Methodist missionary saw his pupils as the clergymen and lawyers of the future (Ibid.).

Sterling (Gordon, 1962) saw the necessity of the Negro Education Grant being administered under the aegis of the denominations. Government could not undertake the task for:

(1) The education of the young would be disconnected from the religious instruction imparted by the various sects to adult negroes

(2) Because there is no Public Department for such purposes--and were there a Ministry of Public instruction, or . . a board of commissioners,

(3) The funds now employed by the voluntary Societies in negro education would be withdrawn, and there is little prospect that Farliament would supply the deficiency (p. 149).

Sterling saw the involvement of the Catholic sectors as a very special case. Several thousands of these people were not English speaking. There were few schools among them, and the Catholic clergy expected any school established by government among them should be entirely state financed.

Doubts, too, were held about Catholic ideologies (Ibid.):

The first maxim of Protestantism is that the state of every human being in the eyes of God depends on a personal and individual reception of certain moral and religious principles. Now these when sincerely received become springs of right action, and sufficiently secure the existence of the qualities that the community has an interest in promoting among its members. To encourage the religion of Protestants is to advance the objects for which society itse If exists. But this is not commonly supposed by instructed and sober minded Protestants to 
be at all necessarily true of the tenets of the Roman Catholics. . . yet the Government cannot take the education of Roman Catholic negroes into its own hands and exclude their clergy from interference ( $\mathrm{pp} .149,150)$.

Sterling recommended to the British government with regard to the reality of any design for education in the West Indies (Ibid.) "the immediate diffusion of a higher and more mature education than that of primary or infant school (p. 151)." The object of these schools, he conceived, was to educate boys of all classes and colours between 10 and 18 years of age, whose parents could afford to pay about one shilling per week for each but could not find means to send them to Europe (Ibid.).

Sterling further indicated that "a higher and more mature education," demanded improving of the masters, the selection of whom could not be placed directly into the hands of the Government officers, since school needed still to be supported in part by voluntary contributions (Ibid. p. 152). Gordon says that Sterling's recommendation for the spread of Negro education through the agency of the religious bodies was accepted by the British Government. Normal schools were provided by the Mico Trustees (See Appendix E) with a subsidy from the Negro Education Grant. The Mico Trustees' non-denominational schools also provided education for children in mainly Catholic islands (Ibid., p. 152).

The new Government of Trinidad and Tobago having attained intemal self government signed a concordat with the denominations ensuring the denominational character of 
the schools, incorporating the denominational schools into the Government's policy of free secondary education and subject to the overriding authority of the Public Service Commission, giving assurance to the denominations in respect of the appointment, transfer or dismissal of teachers in denominational schools considered by the denominations unsuitable on grounds of faith and morals.

The 1966 Education Act debated in the House of Representatives, December 8, 1965 was declared by the Prime Minister to be "an attempt to establish a national system of education in independent Trinidad (Trinidad Guardian, December 5, 1965, p. 3)."

Mention was made by some members of the great debt of gratitude the country owed to the churches, which operated most of the secondary schools with the assistance of public funds. The state was regarded as having abandoned to the church its right to educate.

Previous to the Act, the government built schools which they controlled and maintained and the denominations also built schools with or without government aid, which they controlled and maintained.

Claims were made by members of the House of the more efficient operating of church operated schools, but also to the disreputable school buildings the churches maintained.

Before the advent of the present government there were no regulations goveming secondary schools, and there was a lack of integration in the school systems resulting in 
a Iycee type discrimination against the primary school and the supposedly superior social status and stratification of the secondary school. Under the new classification of the Act there has been a unification of the teaching service unrelated to social status or to the school but to the teachers degree of qualification.

The Prime Minister mentioned the tendency to reproduce the literary bias in some secondary schools, which has created a deficiency in other fields of education necessitating the issue of work permits to expatriates.

The Minister was adamant concerning the government's stand on accountability of assisted schools for the use of public funds in view of the repeated abuse by these schools of the 20 percent of their places allotted to entrants from their preparatory junior schools. This, he considered, was the main cause of the declining standards in examinations. Government could not tolerate the admission of some child from a preparatory school because of connections or "contact." "You don't have enough places for qualified people and you take over-aged candidates and use public funds in the process" he said, and regarded it as a "public scandal (Ibid.)."

One newspaper critic (Beckles, 1965) indicated that since the advent of entry by the Common Entrance Examination, the denominational schools had extended their junior preparatory schools. Fees for these schools were comparatively high so that pupils from the well-to-do sections of the society were placed at an advantage in securing school places. 
The Education Act, 1966, has been enacted to replace previous legislature and lay the foundation for a national system of education ( $T$ \& $T$, Education Act, 1966). The Minister may now, according to the Act:

(1) Regulate the opening of private schools

(2) Prescribe textbooks, curricula and practices in all public schools so as to ensure conformity with national standards of education

(3) Establish a National Advisory Committee for advising him

(4) Establish local educational districts. The Denominational Boards shall now act in accordance with any special or general directives of the Minister and shall be responsible to the ilinister for the efficient maintenance of schools ( $p .5 \mathrm{ff}$. ).

\section{Early Attitudes to Education}

Wood (1968) shows that the ethics of the period did

not favor education of the poor:

It must not be forgotten that it was at a time when the benefits of education for the poorer classes were only beginning to be realized in England. The principle was by no means established that the state had a responsibility for the instruction of the young; many held that education should remain in private or ecclesiastic hands as it had been for centuries. . . In Trinidad the main issue was whether education should be secular or sectarian, and until this had been resolved, no progress in raising an ignorant population out of their illiteracy was really possible ( $p .214)$.

It is not surprising that little was done in the period under discussion to provide education for children of former slaves when in England the advocates of primary education for the laboring poor were faced with the inertia of indifference from those who doubted its value or held that it should be provided by charity. Education had not yet been 
elevated into a universal right of men (Ibid.).

In the background were misgivings about the conse-quences of educating the lower ranks of society. Discontent and aversion to agriculture might be instilled in those whose proper role in life was to use their muscles and not their minds. In the last resort it might bring ruin to the economy and disastrous upheavals to society. Behind these doubts lay the deep philosophical question of the nature of man and the nature of the negro in particular, and whether he was educable (Ibid., pp. 214, 215).

Woods says that the modest and paternalistic ideas of $c$. J. Latrobe who reported to the Imperial Government in 1838 on negro education in the West Indies, were far from realization. Wood quotes Latrobe as saying (Idem, 1968): - . it must be a sober education; one rather calculated to discipline the mind and bring it into subjection than to excite it, one suited to the necessities and probable prospects of the class to whom it was presented; and above all, an education not merely based on worldly morality, but built on the Holy Scriptures (p. 213).

Wood says that, to Lord Harris, education was a most interesting subject. He had once taught school when a young man, and he perhaps alone in Trinidad was conversant with the latest pedagogical theories. He raised the debate to a higher intellectual level. Education was not the mere chore of doling out the minimum of instruction to satisfy the Colonial Office and the friends of the negroes in Britain; rather, he saw it as the most valuable means to improve the standards of the laboring classes and to raise those who could profit 
by it to higher ranks of society. The idea of "wholesome subjection" was unacceptable to him. Rather, the dawning powers of young minds were to be fostered so that their innate potentials could be realized (Ibid., p. 218).

Wood presents Lord Harris' comprehensive and ultramodern ideas of education. Instruction in the schools was to be secular and was to combine intellectual with industrial or vocational training. It was the first time that the role of the state was heard and with it a distinction drawn between education and instruction (Ibid.):

Education has to do with the whole constitution of man, his religious convictions, his moral sentiments, his intellectual capacity, even his physical powers must be affected by it; it should be confined neither by place nor by time; it must be if not neglected ever going on so long as life continues, but instruction has reference more to the cultivation of the intellect, with some of the departments of the former, the Government does not take upon itself to interfere, but it has a right to require that its citizens should not continue in ignorance, in order that the state may not suffer from the vices and errors which ignorance is likely to induce ( $p, 222)$.

In Harris's plans, education and the reorganization of local affairs went hand in hand in the grand design of instilling into the post emancipation population "the feelings, the habits and the forms of a society--for until the present time," Harris wrote in a private letter to Grey (Ibid):

. Legislation appears never to have attempted the solution of any higher problem than the following-viz.: what quantity and what sort of law is necessary to keep a population in order and at the same time to ensure the production of the greatest quantity of sugar. The island would seem to have been considered as one large English speculation, in which the greatest return for the capital expended was the sole subject for the contemplation of the legislators (p. 220). 
In the second part of his address before the legislative council in 1847, Lord Harris introduced his plan for ward schools. Every child in Trinidad would be given the opportunity to advance as far as his capacities allowed, the aim was an education open to talent. In the future Lord Harris hoped that a college would be set up for the ablest children of all, whatever their circumstances of birth (Ibid., p. 221).

The West India Royal Commission (1945) reported that: "The administration and finance of schools are often so divided between Government and private institutions (notably the Christian denominations) as to render difficult the formulation of an educational policy, let alone its vigorous and consistent execution (p. 92)."

The report continued: "The natural criticism is frequently made that, however valuable their services to education may have been in the past, the denominations have now played their part and that government, which already provides such a large proportion of the cost of education, and which in effect controls it already should formally assume the whole responsibility (p. 93)."

"With occasional exceptions, the period has ended when the churches could look outside the islands for any substantial support, and government assistance has increased until, at present the denominations' functions are mainly confined to management and the provision and maintenance of school buildings. Even in this respect it is increasingly usual for 
government to grant assistance for buildings, books and equipment (Ibid.)."

Lack of Common Social Interest

The Moyne commissioners deduced from the evidence presented to them that a characteristic of the West Indian islands was the "regrettable absence of those factors and traditions which elsewhere make for social cohesiveness and a sense of membership of a community (Ibid., p. 94)."

Almost the only agency which exercised any integrating effect were the churches. Even these, however, produced sectarian divisions.

Many of Lord Harris' ambitions remained unfilfilled. No evening classes for adults, no lending libraries, no industrial instruction, and the Ward Schools, where it was hoped the laboring classes of all races would mingle, remained the preserve of African Creoles. The schools were shunned by the East Indians and the children of liberated Africans were slow in attending them (Wood, 1968, p. 230).

Lack of Official Interest in Ward Schools

Wood reports that the final departure of Lord Harris from Trinidad was followed by nonchalance and neglect of the ward schools by the wardens and the Board of Education. Apart from persons of education in Port-of Spain and San Fernando, the countryside was "intellectually arid" few of the planters, managers and clerks would ever have the time or interest to have been active in local affairs. According to Wood, war- 
dens tended to neglect the schools which they were expected to visit regularly. This neglect he attributes not to pressure of work alone. The wardens were against education of the laboring class. He cites the instance of a Warden who when asked by cocoa-farmers to open a school in their area, indicated that the ultimate consequence of educating the labouring population would be a labour shortage on their estates (Ibid., p. 228).

Wood thinks that the warden frankly expressed what was in many minds, and hypothesizes that there was a failure of the will as well as a failure of administration "to cause the plans of Lord Harris to go awry (Ibid.)."

The Collegiate School, according to Wood, was academically a success, for the caliber of the students was declared by examiners to be as good as that in English schools (Ibid. . p. 234).

It was, however, considered a failure in the broader context of social life, a symbol of English Protestant intransigence; "a triumph over the Catholic Community of the island (Ibid.)." And the slur cast on those of illegitimate birth was regarded as an insult to and alienation of the black and coloured population (Ibid., p. 234).

The Catholic community reacted by setting up their own school in 1863, The College of the Immaculate Conception, staffed by Fathers of the Congregation of the Holy Ghost, which at once became a rival to the Collegiate schools. There was accommodation for boarders and their was no ban on ille- 
gitimate pupils yet the poor were still without access to this higher education since the college was financed entirely by donations and fees. The school was thus less exclusive since it reached down to the lower ranks of the whites (Ibid.). Brathwaite (1958) says that "Emancipation laid the basis for a West Indian community and nation, but it did not go so far as to break the organic connection with England. For the rest of the 19th century the society was largely content with the provision of secondary education for the middle classes, with those who could afford it joining the upper classes in sending their children abroad (p. 15)."

\section{Political Factors}

The Minority Report of Dr. Solomon, Constitutional Reform Committee, Trinidad, February 1948, (Augier \& Gordon, 1962) indicated that "It is right that power should pass from the hands of a single individual (in this case the Governor) to a democratically elected body. . . (p. 277)."

The constitutional changes of 1950, which saw the introduction of the new ministerial system, resulted in a great upsurge of interest in secondary education and establishing of secondary schools for now the broad masses of the people were to enjoy the privilege of education.

Under the dynamism of the Feople's National Movement led by Dr. Eric Williams, a degree of common political interest was generated in the country as people of the various races joined hands to form a multi-ethnic party. The educational interest of a people aspiring to nationhood could no 
longer be slighted and in 1952 a number of new religious bodies were given recognition by government for the purpose of establishing and conducting assisted schools in the colony. These included four non-Christian bodies, the Anjuman Sumatul-Jamaat Association, the Trinidad Muslim League, The Sanatan Dharma Viaha-Sabha and The Kabir Panth Association ( $T$ \& $T$ Triennial Survey, 1959, p. 20).

As the Moyne Commissioners (Moyme, 1945) indicated "Education and social progress, indeed must go hand in hand if either is to be of permanent values, and cannot in fact be separated from each other ( $p, 108)$."

Williams (1962) quotes the under-secretary of state in December 1832 on the eve of emancipation as looking forward to devising "some mode of inducing them to undergo the regular and continuous labour which is indispensable in carrying on the production of sugar. . . (p. 87)" and "that it would be greatly for the happiness of the negroes themselves if the facility of acquiring land could be so far restrained as to prevent them, on the abolition of slavery from abandoning their habits of regular industry (Ibid.)." Williams further states that the planters made it quite clear that in their opinion the development of Trinidad's economy was to be based on sugar and on the large plantation (Ibid.). The philosophy of the times regarding the nature of man was not conducive (except among some of the missionary societies and rare humanitarians like Lord Harris) to the establishing of a society which gave "parity of value" to 
the Negro with metropolitan peoples.

The political scientist, Williams (1962), comments on the philosophies of Anthony Trollope, the distinguished English novelist, Thomas Carlyle, the great essayist and historian and James Anthony Froude, the professor of Hodern History at Oxford, all of whom regarded the Negro as defective in character and incapable of governing himself in a state of freedom. Even Queen Victoria through her Secretary of State for the colonies saw the prosperity of the working class to depend on their working for their masters ". . steadily and continuously, at the times when their labour was wanted and for so long as it is wanted (Ibid., p. 90)." William G. Sewelf (1860, pp. 310-325) writes at length extolling the blessings of freedom and free labor in the West Indies and shows that emancipation was a success. Lord Elgin, Governor to Jamaica, in reference to immigration of East Indian indentured labourers, in a letter to Lord Stanley, Secretary of State for the colonies, condemned the resort to immigration (Williams, 1962):

I have always considered a reliance on immigration exclusively, as the only practicable and available remedy for the material difficulties of the Colony, to be a serious evil, and averse to its best interests. At the time to which I refer, it had already led to a reckless expenditure of the public funds. It was based on the hypothesis, expressed and understood, that the system of husbandry pursued during slavery was alone suited to tropical cultivation. Its tendency therefore was to discourage agricultural improvement, and to retard the growth of that more intimate sympathy between the enlightened friends of the Planter and the Peasant which I was so desirous to promote (p. 97). 
It is the opinion of Williams that

The British decision to maintain the Crown Colony of Trinidad as a plantation economy and to authorize the recruitment of a new supply of labour on contract guaranteed that Trinidad would become a great worshop, that no further account would be taken of the race that had been freed, that a new race would be brought in which would subsequently have to be freed, and that the formation of a society as well as a miniature state would have to be deferred for over a century (Ibid.).

\section{English Laissez-faire}

Southgate (1958) supports the view that laissez-

faire was a 19th century ethic:

The principles of laissez-faire were generally accepted; there was full belief in the virtues of full and free competition--between men of the same class and also between class and class. Nor sort of public regulation or restriction was attempted in connection with the erection and equipment of factories, many of which were buildings which had originally been put up for other purposes, and these were usually far from satisfactory. When factories were specially built they were designed with a view to securing the maximum of profit for their owners, and no thought was given to the health, comfort, convenience, and safety of the employees (p. 179).

- Yet politicians and economists were convinced that it was essential to the prosperity of industry that it should be left alone and that it would be improper for the State to interfere in the "free" contract between employer and employee. It was held that the best possible contract of employment, the one which would be most satisfactory, was necessarily that which was reached as the result of master and workman bargaining together without outside interference (Ibid. p. 180).

Opposition to factory legislation on doctrinaire grounds--that the State ought not to interfere with conditions of labour at all--was strong in the first half of the century but less so in later years, when laissez-faire views became less fashionable. Evidence of the evils of overwork was too strong, and public opinion became converted to the necessity for regulation. Nevertheless the champions of individualism clung to the "optimistic" 
view that the evils were exaggerated and that in course of time things would right themselves without State interférence (Ibid.p. 182).

The passing of the Act of 1850 marked the virtual abandonment of the principles of laissez-faire with regard to work in textile factories. Factory law as it existed in 1850 was applicable directly to children, young persons, and women; indirectly it controlled the hours of labour of men also, in so far as the work of the latter was dependent upon that of other classes.

Wardle (1970)sees this ethic extending into the area of education:

Enormous importance was attached by the utilitarians to the individual's right and duty to look after his own business, and there was an intense suspicion of interference by the state in private affairs the sphere of "private affairs" being very liberally interpreted. This individualism was very deeply ingrained into nineteenth-century thinking on political and social matters, and was one of the chief obstacles to the establishment of a national system of elementary education ( $p .3)$.

Wardle quotes Bertham's "Mianual of Political Economy" :

The general rule is that nothing ought to be done or attempted by government. The motto, or watchword of government on these occasions ought to be--Be quiet (Ibid.. p. 4).

It was statements such as these, Wardle says, which Ied to the use of the phrase 'Iaissez-faire' to describe the views of the utilitarians upon the functions of government. He also adds (Ibid.):

- . the new urban proletariat lay quite outside the existing social and political organization - municipal authorities were frequently quite indifferent to the social problems that were appearing within their nominal jurisdiction, for local government shared with national government in a decline in energy and confidence due to the "laissezfaire" doctrine (p. 30). 
In discussing the view of Samuel Smiles that technological ability was an innate factor, Wardle (1970, P. 30) points out that such views found support in the laissez-faire doctrine which taught that education was very much a personal affair, and that it was certainly not the duty of the State to interest itself in the matter.

Lewis (1968), in relation to colonial relations, says that laissez-faire principles were applied in the West Indies:

Trusteeship, as an operative reality, never really got off the ground. Originally enunciated by Burke in 1782, it was the stated first principle of British colonial rules. But the date of slavery emancipation (1834) almost coincided with the year (1832) heralding the victory of laissez-faire in English life involving, pretty rapidly, the application of that dogma to a West Indian post-emancipation society which required planned social reconstruction and vast economic expenditure if trusteeship was to mean anything (p. 110).

Lewis, in continuation gives a picture of laissezfaire in the West Indian society and an absence of social will. He says (Ibid):

At the bottom of the social ladder there were, of course, the ex-slave masses, reinforced by East Indian and Chinese immigrants in, variously, Jamaica, Trinidad, and British Guiana. Where they were not harassed by white and brown-controlled machineries of law and government, and by oppressive land tenure systems, they were openly neglected. Nothing was done to train them in the new duties of citizenship. The slave regime was dead. But it was replaced by a regime almost equally oppressive, imbued still with the slavery spirit (p. 78).

Lewis also sees the hopes of European civilizing

influence as not being realized in West Indian societies:

The general outcome was, the society remained after 1834, and well on into the modern century, a basically disorganized society, with very few common values rooted in common experience. The 
social differentiations, based partly on property, partly on colour, remained fairly static for nearly a century, with the tempo of slow change quickening somewhat during the $1920^{\prime} \mathrm{s}$. Each group "knew its place (p. 79).

He adds:

The demand, thus, was the revolt of West Indian peasant and worker against a society in which despite formal emancipation, they were still regarded as supplies of cheap labour to sugar kings and oil barons in search of quick fortunes. Slavery had been abolished; but the economic foundations of slavery, especially in the general picture of land ownership, had remained untouched . . the social pattern of slavery, the vast masses labouring in poverty on the property of the minority remained stamped on West Indian life (p. 88).

\section{Official Investigation of Social Conditions}

The Disturbances Commission of 1937 declared officially (1938):

We have evidence that some employers manifested a due sense of responsibility for the material well being of their work people. Others, particularly those engaged in the sugar industry, appear to have displayed a lack of regard for the well-being of their labour which has clearly been such as to create an underlying current of resentment. In no direction is this lack of regard more apparent than in the deplorable conditions in which a large number of the labourers and their families are housed (p. 75).

The disturbances in Trinidad and other West Indian islands led the British government to appoint a royal commission in August, 1938 "to investigate social and economic conditions in all the West Indian territories, and to make recommendations." The comprehensive report produced by the commission under the chaimanship of Lord Noyne, is regarded as the biggest indictment of crown colony government in the West Indies made by anybody in the nineteen-thirties, because 
it revealed so many details of the inadequacies of the system. The Report (1945) brought to light the distressing conditions under which people worked and lived in towns, on estates and small holdings; the ill-health, the inadequate education, the infantile mortality and juvenile delinquency. The Report declared with startling candor, "The efforts of Your Majesty's Government and of the Colonial Governments concerned have failed to make for radical reform. We therefore conclude that the means do not exist for effecting improvements on an adequate scale (p. 238)."

Report of Sir Frank Stockdale, K.C.M.G. C.B.E., 1943-44. The Colonial Development and Welfare Planners recognized that pressure of population and lack of remunerative employment was not new in the West Indies. It was relieved somewhat by immigration to the Panama Canal zone to the United States and Cuba after the first World War.

Stockdale (1945) showed that the total amount of financial assistance required in the area would be "far more in excess of what was originally contemplated (p. 2)."

Economic Conditions

The Stockdale report added (Ibid.): "The basic poverty which was frequently encountered in the West Indies might often become so acute as to make social planning impossible, or at least too difficult to achieve by the application of the resources then at the disposal of the people of the colony or district concerned. In many areas poverty, 
ignorance, overcrowding, unemployment, illness, discontent and even despair may be so overwhelming as to touch the emotions of the most dispassionate of scientific observers (p. 82)."

The Legislative Council, October 1944 stateds

The decision to work on a severely practical basis was inevitable since the community could not bear the cost of adequate social services until the economic situation had been improved, and it was undesirable from many points of view that services should be established on the assumption of continued assistance from the Imperial Treasury for an indefinite period (Ibid., p. 80).

Another obstacle to any marked improvement in the general standard of living, the Stockdale Report added, was the lack of sufficient productive employment. "Sugar estates could provide a regular week's work for little more than half the workers on their payrolls, and this was also typical of other agricultural industries as at present organized(p.13)."

Greater industrialization was thought to be possible

in some parts of the West Indian island (Ibid., p. 15).

The Colonial Secretary Criticizes "Laissez-Faire"

While we all deplore the loss of life and the sacrifice that these disturbances have entailed I feel that we are entering on a new era in the history of Trinidad, more particulrly in regard to relations between government and industry on the one hand and labour on the other.

Almost a year ago today the Wages Advisory Board submitted their report to. Government. . . The grievances and hardships that prevailed in this colony were set out clearly in the report and yet the members of the Board were not able to suggest any real comprehensive remedy for those grievances...

In the meantime the cost of living has risen and on the other hand Government and many industries 
in this colony have prospered. The result is that the situation which was serious at the time when the Wages Advisory Board reported has become aggravated.

In the past we have had to salve our consciences with humbug and we have had to satisfy labour with platitudes. Those days have gone by; we can no longer say to labour we recognise your hardships but we canafford to remedy them. We have got to look at the matter from a different aspect. Today Government is collecting large revenues and the oil companies are paying big dividends. Even sugar is now to a considerable extent more than paying its way. . . .

There can be no question today of these three employing groups, Government, the oil industry, and the sugar industry being able to pay a fair wage and to provide decent conditions for its labour

(Augier \& Gordon, 1962, p. 210)

Report of Unofficial West Indian Conference, Dominica, 1932 (Ibid.):

Crown colony rule unquestionably stands today at the bar of public opinion throughout the Caribean archipelago indicted on three major counts: firstly, that it is wasteful and inefficient, secondly, that it discriminates among the various sections of the population, and denies equal opportunities to those whom it governs, and whose happiness and advancement it should seek impartially to promote; and thirdly, that it is indifferent to public criticism and popular aspiration as expressed by the elected representatives of the people, so that instead of a fundamentally harmonious and fruitful co-operation between government and governed there exist in most of the West Indian islands two hostile camps, one displaying an arrogant and calculated contempt of popular desires and opinions, and the other a sullen and suspicious resentment of all the acts of government, a state of affairs, which, inevitably, reacts unfavourably on both camps to the detriment of the peace and progress of the community as a whole $(p, 274)$. 
Hypothesis and Assumptions

From a consideration of the data the investigator will seek to test the validity of the following postulations:

Hypothesis

The absence of a community of interests in Trinidad and Tobago resulted in an inequality of provision for secondary education.

\section{Assumptions}

The following assumptions are postulated as being factors of the plurality of interests:

1. The post-emancipation plantocracy was not interested in the educational and social advancement of the laboring classes.

2. The nineteenth century European ethic of laissez faire was reflected in the prinidad society.

3. British interest in the maintenance of a sugar based economy supported by low-cost labor and indenture resulted in the social and economic neglect of the proletariat.

4. Inadequate central control under the Dual System of óperation of schools delayed the development of education.

5. A competitive and selective system of entrance to externally oriented examinations was not relevant to the country's needs. 
CHAPTER II

\section{HISTORICAI BACKGROUND OF TRINIDAD AND TOBAGO}

Columbus began his third voyage to the western hemisphere on May 30, 1498, and sighted the island of Trinidad about eight weeks later. He christened it "Ia Isla de la Trinidad on Tuesday, July 31, for he had resolved when his ship had been becalmed in the doldrums to name the first land he should discover in honor of the Trinity (Garcia, 1965. pp. 35. 36).

He is alleged also to have sighted the island of Tobago. He did not land on Tobago, but leaving Trinidad, continued his voyage to Hispaniola. Tobago thus remained in its primitive repose for many decades, untouched by Europeans, and retaining its Amerindian name "Tobaco" (later corrupted to Tobago), which indicated the importance of the tobacco plant to the aboriginal Indians (Williams, 1962, p. 8). Trinidad, which was inhabited also by Amerindian tribes, the Arawaks, remained for three centuries no more than a distant colony under Spanish rule.

\section{Spanish Rule and Settlement}

The conquistadores who followed in the path of Columbus had come to the New World in search of el Dorado, not to till the earth. But no el Dorado was found in Trinidad. 
The hills were covered only with verdant virgin forest as they are in many parts even today.

In Trinidad, as in other West Indian islands, the Amerindian population was requisitioned into the labor force as the inevitable conflict began between the aggressive Spaniards and the cool and complacent Arawaks. Unused to the demands of the type of labor required of them by this foreign intrusion, the Amerindians fared poorly. Their numbers were reduced through forced labor, new diseases, and harsh treatment (Ibid.).

Trinidad remained under Spanish rule for three hundred years, but was never seriously hispanized. In 1676. the colony was attacked and conquered by the French, but, instead of remaining to enjoy the fruit of their victory, they plundered the town, carried off everything that was valuable, and left the island once more in possession of its former inhabitants (Moister, 1866, p. 370).

By the end of the eighteenth century, under the impetus of the industrial revolution, a new interest in settlement had already begun throughout the Caribbean. Tobacco, cocoa, and spices were needed for the European market, and finally the intensive cultivation of sugar-cane grew into prominence (Rubin \& Zavalioni, 1969, p. 15).

\section{Immigration and International Rivalry}

It was sugar which came to dominate the West Indian scene, contributed largely to the shaping of the history of Trinidad and Tobago, and to the development of creole insti- 
tutions, and which directed the course of European capitalism (Ibid.).

Meanwhile, Britain and other metropolitan powers contended for commercial advantages in the Caribbean. In order to promote the development of her neglected territory, Spain in 1783, by the "Cedula of Population," opened the doors of Trinidad to foreigners who were natives of friendly nations and states and professed the Catholic faith, provided that they were willing to pay allegiance to the Spanish crown (Garcia, 1965, p. 191). Further immigration was undertaken under pressure of circumstances.

In the West Indies, the reign of French terror had dislocated not a few French royalists and free colored refugees. Some of these found their way to Trinidad (Ibid., p. 92). The Spanish governor of the island, in his communique to the Prince de la Paz, about 1796, indicated also that the English were attacking the French islands with the result that many of the republicans, who managed to escape, many of whom were Mulattoes and Negroes, were entering the island where there were no forces to prevent them (Williams, 1962, p. 49).

Thus in the space of 14 years, the population of Trinidad grew from 126 whites and 310 slaves in 1783 , to 2,400 whites and 10,009 slaves in 1797. Free colored were 245 in 1783 and 4,900 in 1797. French settlers with African slaves had arrived as early as 1777 from St. Lucia to set up small farms on which they cultivated sugar-cane, coffee, 
cotton, and cocoa. This large influx of French influence resulted in the creation of a virtually French society ruled by Spain (Garcia, 1965, p. 192; Williams, 1962, p. 48).

\section{British Conquest of the Islands}

The infusion of human resources by the French, though of immense economic benefit to the country, did not bring repose to the Spanish governor. It had been accompanied by a stealing of many slaves from nearby British possessions. As a consequence, early in 1797, Ralph Abercromby, with 18 ships and 7,650 men, entered the Spanish naval waters to do battle with the Spanish admiral Apodaca's 4 ships and 500 men. Apodaca saw wisdom in setting fire to his ships in Chaguaramas Bay. Out of prudence, Chacon, the Spanish governor, capitulated on February 18, 1797 without doing battle. The formal acquisition of the island by the British took place in 1802 at the Feace of Amiens, five years before the abolition of the slave trade by Britain (Garcia, 1965, p. 192) Tobago was also recaptured finally by Britain, and the acquisition ratified in 1814. The island was constituted a ward of Trinidad on October 20, 1898 (Williams, 1962, pp. 139-151).

As has been mentioned, there were at the time of the British conquest in 1797, 10,009 slaves in Trinidad out of a total population of 17,718 (See Table 3). Previous to this, the interest of the Spaniards had not been in the intensive cultivation of the land, and the French colonials, who had been driven to the island by pressure of political distur- 
ANAIYSIS OF POPULATION OF TRINIDAD AT TIME OF CONQUEST, 1797

$\begin{array}{lrrrrr} & \text { Whites } & \text { Colored } & \text { Slaves } & \text { Indians } & \text { Totals } \\ \text { Men } & 994 & 1.196 & 4.164 & 305 & 6.659 \\ \text { Women } & 590 & 1,624 & 3.505 & 401 & 6.120 \\ \text { Boys } & 301 & 898 & 1.232 & 190 & 2.621 \\ \text { Girls } & 266 & \underline{758} & 1,108 & \underline{186} & \underline{2.318} \\ \text { TOTALS } & 2,151 & 4,476 & 10,009 & 1,082 & 17.718\end{array}$

A British survey printed on a map titled "Plan of the Isle of Trinidad from actual surveys made in the year 1797" (London: Robert Laurie and James Whittle, 1800) lists the population as shown above.

Source: Vera Rubin and Marissa Zavalloni, We Wish

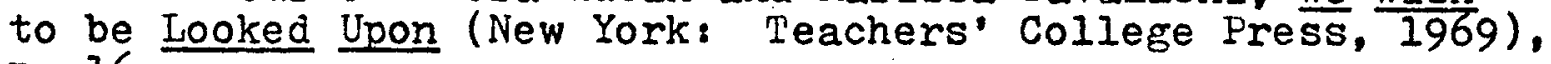
p. 16. 
bances, had been concerned with the development of the small estate. These small units were quite unlike the large estates later developed by the British who were concerned with intensive cultivation with a view to establishing a highly productive plantation economy (Rubin \& Zavalloni, 1969, p. 16; Williams, 1961, p. 3):

\section{Abolition of the Slave Trade and Emancipation}

A plantation system, however, demanded a large supply of labor. Since the acquisition of Trinidad had occurred at a time when more than half of the slave trade was in British hands (Parry \& Sherlock, 1956, p. 180), and not many years away from the abolition of slavery in 1833, some source of cheap labor had to be tapped, since the vast majority of the population in the island would be desirous of using their new-found freedom for their own independent pursuits. It could not be expected that the interests of the freed slaves would continue to be identified with those of an influential minority "whose main concern was to preserve as much as possible, a way of life which gave them personal wealth and privilege in the West Indies (Augier et al., 1964, p. 158)." The newly acquired colonies were especially hard hit by abolition in 1807. Estimates of between 250,000 and one million blacks were given as necessary for the cultivation of all the arable land in the island. As a consequence. various attempts both legal and surreptitious were made to recruit labor. With the possibility of emancipation in the 
offing, efforts were put forth to obtain a labor force among Portuguese, free Africans and Amerindians from other areas, and a few Chinese were brought in under contract. These schemes were all abortive and resulted only in increasing the heterogeneity of the population, since some of the laborers elected to remain in the island after the expiration of their term of contract (Garcia, 1965, p. 228; Rubin \& Zavalloni, 1969, p. 16).

Meanwhile, the abolitionists in England prudently bided their time for carrying through Parliament proposals for ameliorating the condition of the slave population with a view to their ultimate freedom (Garcia, 1965, p. 229). In March 1824, the famous "Draft of an Order in Council for Improving the Condition of the Slaves in Trinidad" was issued (Harlow \& liadden, 1953, p. 567).

In 1831, the Abolition Society began to campaign vigorously to enlist public opinion against the contiuance of slavery. There was need of a reform in the British Parliament to bring in new members who would be sympathetic to the cause of the abolition of slavery* (Augier et al., 1964). The period was one of striking change. The abolitionists found in the new group of rising influential manufacturers and businessmen the support and voters they needed. Among these were many who had petitioned for the removal of slave

* Suffrage in England at this time was based on property qualification. The land owners were therefore the ruling class. There were also members of Parliament among the absentee land owners of the West Indian colonies. 
trade, and had been deeply touched by the martyrdom of John Smith in Guyana and the maltreatment of another missionary, Thomas Shrewsbury, who had been driven from Bardos and his home and church destroyed. The anti-slavery campaigners represented slavery as a crime before God and a threat of racial war in the West Indian colonies. Their cause was helped by the arrival of two Baptist missionaries, William Knibb and Thomas Burcell from Jamaica with authentic reports of the uprising in that colony, and by the despatches of the governor of the island to the Colonial office (Ibid., pp. 156-158).

The West Indian planters, by 1833, found themselves without political connections in addition to being faced with a competitive sugar market. In the reform government, there were members who were as eager to end slavery as to stop child labor in English factories. Some members of Government viewed continued economic relations with the West Indies as being unprofitable, and others considered the amelioration policy to have been rendered ineffective by the recalcitrant attitude of the planters. It was now clear that any compromising attitude toward slavery was not viable. The bill for emancipation was introduced in Parliament early in 1833. By August of that year the Emancipation Act was carried through, to become effective from August 1, 1834 (Ibid.; Parry \& Sherlock, 1956, pp. 175-186).

\section{Apprenticeship and Full Freedom}

The Act of Emancipation did not bring immediate 
freedom. A period of "apprenticeship" was required which would terminate in 1840. One historian, Matheison (1936) states that "as a social institution slavery disappeared... and it came back as a system of industry, the Negroes . . having to work as slaves for so many hours a week (Parry \& Sherlock, 1956, p. 191)." This arrangement served to maintain the former status of the negroes, and to "generate additional popular resentment against the alliance of planters and colonial assembly politicians who had hoped by that means to maintain the spirit of slavery under the letter of freedom (Lewis, 1969, p. 71)."

In 1834, the half-free slaves, assembled before Government House in Trinidad. They were informed that emancipation did not bring immediate and absolute freedom and that there would be an interim period of six years during which they would be compelled to work for their former masters as wage earners. They had shouted in protest, "Point de six ans: point de six ans: (Wood, 1968)."

Now, as a consequence of existing evils during this apprenticeship period in Jamaica, it was finally decided in 1838 to do away with apprenticeship altogether. "Full free" was introduced before the new society had quite adapted to the new conditions of life (Garcia, 1965, p. 238).

There was no wholesale departure of the freed people into the bush as was expected. The Negroes had come to desire more of the material things of life. They needed money for fashionable clothes, to buy plots of land, and to cele- 
brate wakes. Their principal sources of income were the estates, though they no longer desired to live on them. Some, especially the women, took up small trading and hawked various goods around the estates and villages; mangoes, guines grass, calicoes, muslins, linen, ready made clothes, flour, salt pork, porter, wine, brandy, gin, and tobacco (Wood, 1968, p. 48).

The attitude of the ex-slaves toward the estates varied according to the various opportunities that were available. Where there was land available upon which they might squat or which they could purchase, they left the estates in large numbers, and took up small farming, or near the estates, they became part-time workers. Naturally, with the reduction in the labor supply there was an increase in the rates of pay (Augier et al., 1964, p. 186).

\section{The Search for Low-cost Labor}

As has been mentioned, the shortage of labor and the undeveloped state of much of the arable land demanded an altermative supply of workers. The laws of supply and demand were applied in order to solve the problem.

A committee of the House of Commons, which studied the West Indian colonies, advanced, among other things, that "one obvious and most desirable mode of endeavouring to compensate for this diminished supply of labor is to promote the immigration of a fresh laboring population, to such an extent as to create competition for employment (Williams, 1962, p. 96)." 
Among the immigrant workers, some came from China, Madeira, and some of the other West Indian islands. None of these proved as reliable as was desired.

During the British post-emancipation period, slave trading was still carried on in Cuba and Brazil. Nany African slaves destined for these countries were rescued from the slavers by the British naval ships, and liberated in the British West Indian islands. About 8,390 of these arrived in Trinidad after 1838.

The greatest and most reliable source of supply was India, from which the first immigrants arrived on May 3 , 1845. These came under contract, known as indenture, for periods of five years. During this period of service, they were compelled to work, and had the option of returning home on termination of their contract, or of renewing it. By 1917. when indenture ended, about 145,000 East Indians had entered the country, thus making a drastic change in the demographic composition of the island (Ibid., p. 10; Wood, 1968, p. 113; Augier et al., 1964, p. 208). 


\section{EDUCATIONAI PROBLEMS FACING TRINIDAD AND TOBAGO}

The principal problems of education in Trinidad and Tobago in recent years have been overcrowding in the primary schools and the discrepancy between the number of primary school-leavers and the capacity for enrollment in the second cycle of education. Concommitant with these has been the system's inefficiency: the insufficiency of technical and vocational education, of adequately trained teachers, and the emphasis on grammar school type of education.

This chapter is devoted to a consideration of the country's educational requirements at the post-primary or secondary school level. The interpretation will be applied in succeeding chapters in relation to the assumptions which have been made.

"Secondary Education" is described in the Education Act 1966 as that "which shall consist of full-time education suitable to the requirements of senior pupils who are under the age of 20 years (p. 6)."

\section{The Concern for Equal Opportunity}

Administrative concern has not been with preserving in a framework of equal access a type of education that was originally (Wardle, 1970) "never intended for the education 
of the whole population (p. 138)," but rather that of discovering and providing quantitatively and qualitatively educational opportunities for all learners in the primary and secondary cycles.

The fluid state of the educational system reflects the dynamic quality of all phases of life in the country in recent times. Principal among these is the political advancement of the country to full political independence as a state within the British Commonwealth of Nations. To such an historic and far-reaching decision, matters concerned with educational policy are crucially important; for in the present political status, secondary education should not continue to be (Williams, 1968) "severely restricted to the few" nor be "so little an integral part of any national system of education (p. 31)." Such differentiation in educational provisions, which will be examined in Chapter 6, was characteristic of the colonial past, but cannot be tolerated in a democratic nation in the latter half of the twentieth century.

The Common Entrance Examination and Selection

The Common Entrance Examination which was recommended by the Maurice Committee (1960) was implemented by Government in 1961 to replace the College Exhibition. The object was to remove ethnic and social differentiation in access to secondary education with a view to promoting national consciousness (pp. 3, 23-25). This method of evaluation is, however, not without its pedagogical limitations. Implicit in selection procedures are the subtle variables of socio- 
economic status and home influences on the school achievement of pupils. Studies done in Trinidad and other Caribbean areas as well as in continental areas support this hypothesis (See Appendix $B$ ). In the light of these findings, the introduction of free secondary education in the absence of adequate accommodation for all pupils means that government funds in the public schools are being spent on many children whose parents can well afford to pay, thus reducing the places available for children who could not attend without financial help; and that (CIAP Report on Trinidad \& Tobago, No. IV) the "primary school will remain the terminal educational experience for the bulk of the population for some time to come (pp. 12, 13)."

In $1967,41,538$ ten- and eleven-plus children wrote the Common Entrance Examination.* Of these 5.566 were admitted to public secondary schools (The Sunday Guardian, October 1, 1967). In 1972, however, with the growing aspirations of the youth and consequent increase of pressure for postprimary education, the implementation of the Third Five-Year Plan 1969-1973 for educational expansion provided places for 10,476 of a projected 11-plus age group of approximately 30,000 (Gomes, 1972, p. 69). The demands of expansion of educational facilities are further corroborated by $G$. W. Robert's study on School Enrollment in Trinidad and Tobago 1960. The study indicates that approximately 1 in 3 primary

*Among the unselected children are the many ten-plus who would have a second chance to write the examination before age 12 . 
school children went on to secondary school, 1 in 20 were successful in the School Certificate Examination or its equivalent, and about half of these qualified to proceed to higher education. The need for greater accommodation and the removal of the eleven-plus "bottleneck" is further emphasized by the statistical prediction (The Sunday Guardian. August 4, 1967; Draft Plan, 1968, pp. 7, 97, 98) that by the end of the decade there may be as many as 70,000 children seeking entrance to secondary school. This will entail, in terms of schools to be built and teachers to be trained, a colossal sum of millions of dollars.

\section{The Need for Reorganization of the System}

The Draft Plan 1968 to 1983 proposes a three-tier system of education with primary, junior secondary and senior secondary levels (Draft Plan, p. 3; and see Third Draft FiveYear Plan, pp. 334-335). The need is expressed of providing 109,000 new primary places and 91,000 rebuilt places. This would require to be supplemented by the use of the Shift System in the areas of dense population. The end in view is to curtail expenses at this level so as to free the resources for use on other levels of education so that the primary system can be released from the bottleneck of the elevenplus.

Another need of the emergent society is that of revising the curriculum of the primary school in view of the following developments (Ibid.):

- (1) The changing assumptions and ideas in the 
educational world in respect of teaching methods and the content of syllabuses;

(2) The basic requirements of orientation towards the need of Trinidad and Tobago:

(3) The proposed provision of secondary education for all, which would alter the practical relationship of the pupil to the primary school curriculum (Gomes, 1972, p. 69).

The junior secondary school will provide a threeyear course in a type of cycle d'observation et d'orientation for the age-group 12 to 14-plus, thus meeting the need to replace the post-primary sections of the all-age primary school and the junior forms of some secondary general schools. Selection for specialized education will be done at age 14plus, when consideration will be given to educational and vocational interests, aptitudes and abilities (Draft Plan, pp. 8, 28).

At the senior secondary level, educational reconstruction requires the provision of six comprehensive schools centrally situated in relation to the junior secondary schools, each with large technical wings for vocational and technical training (Ibid., pp. 33-37). A total of 5,000 additional places could thus be provided. Some existing government secondary schools will need to be upgraded to senior secondary general schools to cater for the needs of $0^{\prime}-$ Level and $A^{\prime}-$ Level aspirants. The secondary school system on the whole needs to be provided with more science laboratories and practical workshop facilities.

The development of the comprehensive school is viewed 
as actuated by the need for the reduction of capital and recurrent costs of this very expensive type of education and training: as a means of promoting interaction and correlation between different parts of the curriculum, and as a social necessity designed to give to technical education and technically oriented persons a more influential place in the educational system (Draft Third Five-Year Plan, 1968, p. 335).

Such organization, which the administration is anxious to perfect (Ibid., p. 336) is imperative, since an educated, skilled, and employable labor force in adequate numbers is a fundamental need for the development of Trinidad and Tobago.

The assumptions are here made that (i) the colonial society had been static and ethnically and culturally divided for over 100 years; (ii) at the dawning of independence, the society was socially and economically unprepared to implement the strong igalitarian principles in education which developed in the middle decades of the present century.

\section{The Need for Relevance}

As has been previously stated, a related problem is that of providing the type of education suited to the needs of the society: a society in which the schools have been oriented toward a classical type of grammar-school and preuniversity education preparatory to positions in the Civil Service and the professions. In Trinidad and Tobago, as in most developing countries of the world, over-emphasis on 
such occupations has become anachronistic. In past decades one educator, Broomes (1965) declares, there has been a "whole field of knowledge relevant to our society which the secondary schools did not cater for, because the curriculum by which they worked had been prepared for another society (p. )." In the present age of independence and increasing technology, as the Draft Plan has indicated,

The dynamic circumstances of education in a developing country today have created in Trinidad and Tobago a need for educational planning such has never before been experienced. The constantly evolving needs of the nation contrast sharly with the almost static conditions of the past. iNational objectives in education today are both more ambitious and more diverse ( $p .79$ ).

A Consideration of Objectives for Emphasis Consequent on these aspirations, the Education Working Party 1971, ( $T \& T$ Working Party, 1972) was appointed "to advise on a post-primary curriculum more relevant to national needs and circumstances, and to the preparation of the necessary textbooks ( $p$. 5-9)." The need was felt of giving consideration to:

(a) The position of agriculture especially in rural secondary schools.

(b) Greater emphasis on industrial, technical, vocational and commercial subjects.

(c) Greater emphasis on ivest Indian studies and cultural forms with their implications for the study of foreign languages.

(d) The role of Afro-Asian study and teaching.

(e) The expansion of teacher-training with emphasis on the quality of the training. 
(f) The role of television and radio.

(g) The place which examinations should occupy in the secondary school system and the nature of the se examinations.

(h) The methods of language study and teaching.

(i) The requirements of Sixth Form students (p. 4).

From a consideration of these objectives it emerges that it is of supreme importance for the society to realize that Trinidad and Tobago is rightly called "pluralistic," having had its foundation in Western European and Afro-Asian cultures. The need for having due regard for "this amalgam of cultures ( $p, 6)$ " is seen to present a problem in curriculum development. Many of the traditional subjects and syllabuses of the recognized secondary schools in the territory do not meet the needs of students gifted with some practical and creative talents rather than highly academic aptitudes and interests. This necessitates changes in methods of teacher-training and teaching in the context of the "new" Trinidad and Tobago; for a curriculum mainly geared to obtaining passes at the examinations for the General Certificate of Education is evidently not consonant with national needs.

The Education Working Party saw that a break with tradition on the part of the schools and the Ministry of Education and Culture was of the essence in order to create, with the aid of indigenous institutions, new programs of studies and new emphases. Prominent among these is the objective that all students, whether academically gifted or 
not, be given such an education as would lead to an understanding of the problems of human relationships, of living in unity as one community.

Technical and Vocational Needs

The technical and vocational needs of Trinidad and Tobago must be aimed at bringing its productivity into the stream of present developments in science and technology. The country's industries need to be supplied with "persons possessing developed intellectual resources, certain fundamental skills and a flexibility for further education (Third Five-Year Plan; p. 336)."

As suggested by UNESCO planners (Ibid.), a scheme of technical education should make provision for:

(a) Craft-training on evenings in various centers where physical facilities and teaching resources permit, for the benefit of persons who are either employed or are awaiting employment;

(b) Technical education in the four basic fields of agriculture, commerce and business studies, home economics and institutional management, and technology is relation to construction and engineering metals (pp. 336, 339).

The implementation of this type of program demands hundreds of full-time day-places in technical schools, and the provision of several short courses in vocational training aimed at turning out several thousands of operatives and craftsmen in evening courses and summer programs.

If it is to contribute to the maintaining of a viable economy, education in Trinidad and Tobago, as in other progressive countries, must also develop, as a British educator 
(Peterson, 1968) has aptly stated, "a quality of mind, an openness to new ideas, an ability to go on learning new skills that our industrial and commercial systems demand, rather than the absorption of a body of static knowledge or mastery of a traditional skill (p. 12)."

\section{Needs of Professional Training of Teachers}

The increasing demand for post-primary education and the orienting of the curricula toward the broad life of the community suggests the need for the preparation of a larger number of teachers suitably equipped with adequate academic and professional education and growth experience; teachers who understand their national heritage and duly regard the values of the society (Third Five-Year Plan, p. 336).

Because of the country's limited resources, a consideration of economy of expenditure, of the needed physical facilities and the large number of specialists required in teacher-training suggest the advisability of concentrating the program of teacher preparation in three large colleges instead of the present five.

A great improvement in the training system is seen as desirable; and the introduction of school libraries, physical education, scientific and technical orientation, cultural orientation will require, for effective teaching that trainees be brought into contact with all the necessities in addition to their area of specialization (Ibid.; Draft Plan, p. 57).

The supply of teachers for senior level secondary 
education is expected to be met, especially from 1974, by graduates from the College of Arts and Science of the University of the West Indies (U.W.I.), St. Augustine in collaboration with the Institute of Education offering training for the graduate teachers Diploma in Education (Third Five-Year Plan, p. 337).

The professional training of technical teachers will need to be undertaken through special arrangements between the Technical Institute and the Teachers' Colleges, and the necessary technical personnel for this scheme is expected to be obtained through bilateral arrangements between Trinidad and Tobago and three friendly governments, the United Kingdom, Canada, and the United States of America; as well as through intemational agencies (Draft Plan, p. 62).

\section{Further Assumptions}

(iii) The country was originally intended to be wholly an agricultural area; (iv) educational values in the colonial period were oriented toward the metropolis, not toward internal development; $(v)$ rapid political and social changes in the country in the post-war period stimulated a high demand among the masses for secondary and higher education.

The social and economic factors which are postulated as causes of educational deficiencies will be examined in Chapter 4. 
CHAPTER IV

\section{SOCIAI AND ECONOMIC FACTORS AFFECTING THE DEVELOPNENT OF EDUCATION}

The level and quality of the educational opportunities which a country provides for its people are to a great degree determined by its economic resources. Economic development, inversely, is in contemporary thinking one of the objectives of education. Social and cultural development, too, are intimately related to educational development, and there is a continual interaction between these human activities. By increasing knowledge and specialized skills, education contributes to a rise in a country's productivity. This economic development will consequently stimulate further investment in education. The enlightment and awareness produced by literacy and higher educational development causes further social development which in turn may generate an increasing demand for education (UNESCO, 1970, p. 108).

As history has demonstrated in more than one country, the mere possession of ample economic resources does not itself lead to the building of an efficient system of education. Various factors examined in this analysis, such as tradition, attitudes, social organization and philosophies involved in the quality of the human material must be taken into account. 


\section{Composition and Structure of the Population}

The heterogeneous nature of the population of early British Trinidad has been referred to in Chapter II. In reference to this continued diversity the recent Working Party (1972, p. 6) stated that it was important for the people of the country to realize that the society of Trinidad and Tobago is rightly called "pluralistic" having had its foundation of culture in the countries of Western Europe, particularly Great Britain, France, Spain, as well as in other culture as Africa, India, and China.

The groups forming the social structure of the early post-emancipation period were, in order of importance, the British Government personnel, British merchants, proprietors and planters of influence, some of whom were members of the Governor's Advisory Council, and whites of lesser influence comprising overseers, French and Spanish settlers, subordinate officials and smaller commercial proprietors and planters. The lowest class consisted of the many thousands of the black population who were either former slaves or free and liberated Africans. Between these two social extremes were the developing middle class of coloreds aspiring to the cultural values of the whites, but circumscribed by ascriptions of class and color (Rubin \& Zavalloni, 1969, pp. 20-22).

The system of govermment control from the year 1810 was the Crown Colony instituted out of administrative prudence at a time of preponderant "foreign" influence in the country. It was within this administrative framework that the interests 
of the planters were supported (Hatheison, 1936, pp. 87, 88).

\section{Relations of Planters, Ex-slaves, Free Colored. and Immigrants}

In this heterogeneous post emancipation society, it was necessary that certain adjustments should take place. One of these had to do with the sexual code that was an outgrowth of the numerical imbalance of the sexes that had existed among both slaves and free Europeans, and the defenseless position of the slave women. This led to concubinage, informal unions, and "mistress patterns" on many estates in Trinidad as in other Caribbean societies (Mintz, 1971, p. 28). In the pre-emancipation period there was a large number of house slaves, who were more closely associated with the life styles of the planters. These were given a modicum of education, and some were manumitted even before the passage of the Act of Emancipation. They were thus an elite class of slaves. The progeny resulting from the close contiguity became new racial types possessing and adhering to a higher social status.

It is this offspring of French and Spanish planters and overseers that constituted the "free people of color (Rubin \& Zavalloni, p. 3)." The British, who were more aloof in their relations with their slaves are also known to have fathered mixed progeny, and like the French to have provided for them, even sending their sons abroad for further education (Ibid., p. 20).

The literature indicates that these more humane 
relationships were not the rule. For example, the Chief Justice of Trinidad (Smith, 1810), in a communication to Lord Liverpool, when the Crown Colony status was being debated, spoke of the "laxity of morals and the general absence of education throughout even the better classes of a West Indian colony." He held the view that

To discuss the morality of a community is an invidious task. Yet, what must be the general character of the morality of a class of men among whom not only is concubinage universal and the married state a mere exception to the general rule, but also the parent has so entirely separated from himself the first feeling of morality of nature as to be content to abandon his unprotected female orphan child ... (pp. 92, 93).

These extra-legal relations have continued as a feature of lower-class culture in Trinidad and Tobago up to the 20th century, and have not failed to affect the rate of population growth. This is a significant factor in the provision of school places for the children of the country.

\section{A Legacy of Division}

By general admission, for the existence of any society, a common core of cultural values is important. What is most often met with in regard to Trinidad and Tobago is the idea of the weakness of its social stmucture. This view must be accepted in the light of the evidence of hundreds of memoranda presented to the Moyne Commissioners (Moyne Report, 1945) which caused the Royal investigators to express the "regrettable absence of those factors and traditions which elsewhere make for social cohesiveness and a sense of membership of a community (p. 93)." This lack of national identity in the old 
colonial society has been alluded to by a Trinidad East Indian intellectual (Naipaul, 1962) with striking precisions

Everyone was an individual, fighting for his place in the community. Yet there was no community; we were of various races, religions, sects, and cliques; and we somehow found ourselves on the same small island. Nothing bound us together except this common residence. There was no nationalist feeling. There could be none (p. 143).

It is reasonable to postulate that these fractured community relations of the country originated partly as a result of the dominant role of the plantation, and the longrange effects it has had on the social life of the people with their disparate social backgrounds. In Trinidad, this "iron and clay" weakness was compounded by the introduction of thousands of Indian immigrants of a totally different cultural and ethnic origin.

Whether by design or otherwise, the effect of this racial and cultural diversity was to avoid a clash between the dispossessed workers and the plantation system. (Beckford, 1973, p. 212). Similar situations existed elsewhere--Tamils vs. Sinhalese in Ceylon; Indians vs. Negroes in Guyana, and Blacks vs. Poor whites in the U.S.

\section{Labor Deficiency}

Sugar production in the 18 th and the early 19 th century was regarded by the statecraft of the period as an asset of the first importance to metropolitan countries (Williams, 1944, pp. 85-97). This was undoubtedly related to the expeditions to the Caribbean in the naval warfare between France and Britain. By the mid-19th century, conditions had devel- 
oped in the financial prosperity of sugar which have had a marked bearing on the social and economic development of Trinidad and Tobago and other Caribbean areas. The significance of these developments for education in the region was expressed by the Royal West India Commissioners (Noyne Report, 1945): "Education and social progress, indeed, must go hand in hand if either is to be of permanent value, and cannot in fact be separated from one another (p. 108)."

The planters' economic situation was seriously affected by the attitude of the ex-slaves toward the estates, which varied according to the alternatives that were available. Where land could be obtained by squatting or purchase they departed in large numbers and became small farmers, or, near the estates, part time workers. With the reduction of the labor supply there was an increase in rates of pay.

These unsupportive results of freedom made the planters determine to eradicate squatting from the lands, and for this they obtained the compliance of Lord Grey, the Secretary of State, who advised the passing of a law for the ejection of squatters; raising the price of crown land and using the proceeds to clear land for village lots, which were also to be sold at a high price so that the new ex-slave freeholders "should look to labor on the estates as their main dependence." Grey was also persuaded that circumstances should be so arranged that more labor would be required of the workers to supply their wants (ivathieson, 1936, pp. 87. 88). He was obviously convinced of the victorian concept that 
hard work resulted in the moral uplift of a people. His view was challenged by Governor Harris, who did not think that drudgery of labor could improve the "lower orders" either morally or physically, and preferred that crown lands should be sold cheaply so that the laborers would not be too dependent on those who would not "weigh their interests with an impartial hand (Ibid.)."

Thus the new arrangements did not give the planters the kind of labor they considered essential to keep up production and to meet, in the British market, the competition of slave-grown sugar from other countries, imposed by the removal of "protection" and the abandonment of the exclusive. While they wanted a dependable and docile force of workers with low turnover, they now had intractable mobile workers who were asserting their human dignity and would not be bound by contracts, and constantly sought better conditions of work and existence (Wood, 1968, p. 54).

Williams (1962, pp. 94, 95) has recorded the resolutions pertinent to this issue of the British Parliament, many of whose members owned estates in the West Indies. One of these states that the Act of Emancipation had been productive of good to the character and conditions of the negro population, who had increased in a desire for religious and general instruction and were making rapid advancement in civilization and in the sense of value of property and independent station. On the other hand, the freedom and casualness of labor of the ex-slaves had resulted in a diminution of the staple crop and 
had had disastrous effects on many estates, some of which had been abandoned. The Negroes were able to live in comfort and obtain wealth without estate labor, and were able to obtain land on easy terms. The best way to "compensate for this diminished supply of labor was to promote the immigration of a fresh laboring population to such an extent as to create competition for employment (Ibid.). The natural consequences would be that no further account would be taken of the exslaves. A new population would be introduced from outside to work on terms which the planters thought essential for the maintenance of their profits.

A contemporary North American journalist of the period (Sewell, 1861, pp. 310-325) asserted that the planters were bred to the belief that sugar could only be produced profitably with unfree labor and that they insisted on that fallacy long after serf labor was abolished. A similar opinion was shared by Iord Elvin, Governor of Jamaica, in a dispatch to the Secretary of State (Williams, 1962, p. 97).

\section{Alternative Supplies of Labor}

In these circumstances immigration was introduced. Various sources were tapped. A thousand laborers were brought in from China, and laborers were also introduced from other Caribbean islands as well as North America. The principal source of supply was India, from which indentured workers arrived in May, 1845 (Wood, 1968, p. 113). Among the indentured workers of the 1850 s were also some liberated Africans. 
The scheme for a cheap and manageable labor supply solved the planters' problems for a while but did not contribute to the social advancement of the country. The squalor in which indentured workers were isolated on the plantations in conditions often worse than slavery are indicative of the philosophy held by many proprietors of that period in regard to the welfare of disposed peoples and to the role of man in society. This is illustrated by the attitude of a planter who as late as 1926 expressed little interest in the education of laborers! children, and of another who was little concerned about proper housing for "lying-in mothers (Williams, 1961, pp. 3, 8)."

In the view of a very critical outside researcher (Lewis, 1968, p. 200) it was the planters' influence in the political machinery which permitted them to continue the "harsh servitude of indenture at once technologically and socially degrading (Ibid.)." They were allowed to defray up to one third of the costs of immigration from public funds, so that colonial finances, as Lord Harris indicated, were allowed to be consumed in a most extravagant and only partially successful immigration system to which everything had been sacrificed for the sake of getting an extended cane cultivation (Williams, 1962, p. 100).

\section{Depressed Conditions in Industry}

With the aid of indentured labor, reduced wages, improvements in factory machinery, and the rapid expansion of 
the world demand for sugar, the industry was able to adjust to the market conditions of free trade. But this return of financial property was short lived, for the phenomenal increase of the production of beet sugar on the continent of Europe created competition in the world market that plunged much of West Indian production into bankruptcy. The closing years of the 19th century were a critical period as the continued existence of the sugar industry was in danger. It was in these circumstances that the Royal commision of 1897 was appointed to discover means of restoring the sugar industry and to find if competition of beet sugar was indeed the principal cause of distress in the West Indies. The commissioners were not all agreed on the effects of competition from beet, but were unanimous that the islands were in a state of economic depression and strongly urged the encouragement of all measures having a tendency to maintain the well being of the population. They condemned the emphasis on a single crop that was so sensitive to fluctuations of the world market, attacked the planters for making it difficult for peasants to obtain lands of their own on which to grow food crops, and warned that there was a precarious future for the West Indies which did not give priority to the settlement of the landless laborers on the land as peasant owners. During the world depression another commission in 1930 repeated the recommendations of the 1897 commission (Augier et al., 1964, p. 243; Williams, 1961. pp. 3. 4). 


\section{A Persistence of Dependency}

The plantation system denied the majority of the people a real stake in their country and a chronic "dependency syndrome" (Beckford, 1972) was characteristic of most of the population. This social debility was brought into focus by the Royal commission of 1938.

One of the strongest and most discouraging impressions carried away by the investigators in the West Indies is that of a prevailing absence of a spirit of independence and self-help . . . a tendency on all matters to appeal to government for assistance with little or no attempt to explore what can be done by individual self help... (Moyne, 1945, p. 38).

The commissioners recognized that this "pauperism" was a legacy of West Indian history and counted on the people of Britain to ameliorate the condition.

Education held an important place in Grey's early colonial policy (Norrell, 1930, pp. 241, 242). He believed that education was a vital factor for the realization of the emancipation of the body and for achieving moral and spiritual freedom. He regretted that so little had been done to introduce an industrial element in education. Yet education and social progress, as has been emphasized in this study, must experience a true marriage if either is to be of permanent value. This the Royal commissioners also stressed (Ibid., p. 108). But social progress could not be realized in an atmosphere of dependency. This analysis is supported by the remarkable research on Trinidad youth by Rubin and Zavalloni (1969. p. 22). Planters in the metropolitan groups in Trinidad and Tobago were not inclined to imparting entrepreneurial 
skills to their coloured offspring. There was need of teachers, clerks, doctors, civil servants etc. whom the mother country was unable at that time to provide and some of whom were supplied from the developing middle class of coloreds, who were able to obtain secondary schooling and also emulate the upper class in sending their children abroad. Large business enterprises were to be the province only of expatriates. The slaves and ex-slave population were taught the "Protestant ethic" of honesty, loyalty, industry, but not thrift or capital accumulation, to develop independent business concerns. The missionaries contributed by teaching their converts Christian virtues which would make them more faithful and tractable workers, but the sterner virtues of the "Protestant ethic" which tended to the development of capitalism were not inculcated in either the slave or the free since these were not in harmony with the interests of the planters.

The West Indian educational enterprise is not yet free from the legacy of the metropolis. The masses are still striving toward greater inclusion in the higher levels of education. In Trinidad and Tobago in 1960 (C.S.0.. 1960; Lewis, p. 87) more than 50 percent of the total working class comprised persons whose formal education went no higher than standard VII of the Primary school level. The school with its ascriptions of race and class and by its competitive and selective procedures thus was perpetuating the unhealthy distrust and jealousy of the colonial social climate. Its scholarship system was competitive, anti-social, and tended toward 
cultural alienation.

In industrial employer-employee relations the strength of local businesses lay in the non-existence of effective trade unions, machinery for negotiation, and the inadequacy of industrial law. Official recommendation regarding workmen's compensation, labor departments, health insurance, restriction of child labor, factor inspection, old age pension, collective bargaining were either neglected or unknown on the statute books. Such laissez-faire attitudes were leading to restless rumblings among the proletariat. The hoyme commissioners suggested that powerful vested interests had inhibited progress along these lines. They affirmed that evidence was lacking of any active steps by West Indian Governments to encourage the formation of trade unions. This was a society in which, 100 years after emancipation, the people's status as mere suppliers of labor to "sugar kings and oil barons in search of quick fortunes" had undergone little change. Though there was a formal emancipation, the economic foundations of slavery had varied little. The vast majority of the landless continued to labor in poverty on the property of the majority (Lewis, 1968, p. 88).

\section{Population Growth and Iiving Conditions}

The composition of population found in plantation economies has resulted from the movement of labor demanded by plantations in the past. This was the origin of the Black and East Indian peoples, and to a lesser extent the Chinese, in 
the Caribbean islands. Cultural plurality is therefore a characteristic of the plantation societies of the region. It is the view of Beckford (1972) that plantation owners had a vested interest in encouraging plantation workers to have many children and even used inducements to promote this. They also expected parents to apprentice their children, and resorted to various measures to have them do so (Sturge and Harvey, 1838). At this time the population was small and was pyramidal as shown by a count made in 1838. Its numbers were as follows in Table 4:

TABLE 4

POPULATION OF TRINIDAD BY CLASSES, 1838

\begin{tabular}{lr} 
Race & Numbers \\
Whites & 3,993 \\
Coloured & 12,006 \\
Apprentices & $\underline{20,656}$ \\
\multicolumn{1}{c}{ TOTAL } & 36,655
\end{tabular}

Source: PP 1839 XXXIV, 35, "Negro Education, British Guiana and Trinidad," p. 42 in Wood, 1968, p. 44.

The structure was destined to become more complex.

With the cooperation and financial assistance of the Imperial Government the planters of Trinidad imported large numbers of Indian laborers into the country without due consideration of what this would mean in demographic problems for the future, when many Indians would elect to remain in the country. This they were able to do because indenture was made partly a public enterprise. Public monies which could have been used 
for social and educational development were diverted to the maintenance of the plantation economy. Williams (1969, p. 21) indicates that, in addition to the direct cost of immigration, the thousands of pounds spent on the police force, jails, hospitals and the medical department must be credited to the cost of the system of indenture.

Among the indentured immigrants to Trinidad in the post emancipation decades were chinese laborers some of whom had already arrived as early as 1806, but the majority some 2,500 arrived between 1852 and 1866. They were found to be less inclined to plantation work. It was the East Indian immigration, begun in 1845, that constituted the greatest unnatural increase in the population (Wood, ...pp. 107-159).

Indenture was terminated in 1917 upon the insistence of the Trinidad Workingman's Association, pressure of adverse public opinion in England, and finally the Abolition of Indenture Act of the Indian Legislative Council in 1916. In 1918 the Secretary of State refused to reopen immigration under indenture (Augier et al., 1964, p. 209). Williams ( 1962 shows that by that time not less than 145,000 Indians had entered Trinidad.

A further factor in population increase has been the higher rate of fertility among this ethnic group. The improved health conditions in Trinidad after 1931 resulted in a lower mortality rate. The 1946 census revealed a population increase of 2.97 percent per year, while the rate of increase among the Indian population was 4 percent per year, which was one of the 
highest in the woild (Malik, 1971, p. 6).

Iiving conditions in the early part of the present century left much to be desired in the setting for educational development. For two-thirds of the population, about the year 1911, daily activities revolved around the plantation, the kitchen, the wash tub, the shop counter, the sewing machine, the corner pavement, the roads or the tradeshop (Williams, 1969, p. 16). Slavery had bequeathed a legacy of cheap labor, and indenture a 25 cent wage. The nearly 16,000 applications for poor relief indicated the extent of the existing poverty. With the low wages, the relatively high cost of living, and the number of dependents, the lower class of people found it difficult to accumulate capital (Ibid.). Housing conditions reflected the status of the masses with the majority of the lodgings in Port-of-Spain being of the barrack room type. Methods of taxation favored the absentee interests and well-to-do local people but not the working class, since customs duties provided about half of the island's revenue for 1911, a considerable portion coming from the foodstuffs consumed by the masses. The wealthy resisted various forms of taxation. The instability of domestic unions inherited was accentuated by the housing conditions and the struggle for survival. Forty-three percent of the adult males and 64 percent of the females were unmarried, while 60 to 70 percent of the children were born out of wedlock.

Tropical diseases took their toll on an indigent 
population. Deaths during the fiscal year 1911-1912, principally from waterborne diseases, were 23 per thousand, and the milk supply was known to be an important source of infection. Malaria and ankylostcmiasis affected mainly the rural areas, and tuberculosis the urban areas, while infant mortality was 149 per 1,000 live births (Ibid., p. 18).

These conditions are referred to in order to present the problem of development of education for which social and economic conditions must form the basis.

It is conditions such as these which caused the Royal Commissioners of 1938 to inform the Imperial Government with startling candor (Moyne, 1945 in Augier etal., 1960, p.283):

The efforts of Your Niajesty's Government and the Colonial Governments concerned have failed to make for radical reform. We therefore conclude that the means do not exist for effecting improvements on an adequate scale.

Following World War II, as a result of Colonial Development and Welfare allocations, loans raised on the British market, and systematically engineered taxation, there was improvement of a number of public services, including an expansion of medical services, which resulted in considerable improvement in the health of the people of the country as shown by Table 5 . 
TABLE 5

VITAI STATISTICS 1950 AND 1960

\begin{tabular}{ccc}
\hline Vital Statistics & 1950 & 1960 \\
\hline Birth rate per 1,000 & 37.3 & 39.5 \\
Death rate per 1,000 & 12.1 & 7.8 \\
$\begin{array}{c}\text { Infant mortality rate } \\
\text { per 1,000 live births }\end{array}$ & 80.3 & 45.4 \\
\hline
\end{tabular}

Source: British Information Services, 1962, pp. 37, 45.

There has also been a spectacular decline in the death rate from certain diseases: the death rate per 100,000 from pulmonary tuberculosis fell from 100.7 in 1945 to 13.3 in 1959; from malaria from 76.8 to $\mathrm{nil}$ and from typhoid fever from 20.1 to 3.1 (Ibid.). The resulting decrease in death rates brought about a large increase in the child population. The implication of this for education is that: (1) large commitments even beyond the nation's resources are called for in educational budgets, (2) pressure of population will affect the Iiving standards of the community and the consequent unemployment and underemployment will enhance the difficulty of preparing pupils for life in their environment.

Population growth up to the beginning of the present government of Trinidad and Tobago is presented in Table 6. 
TABLE 6

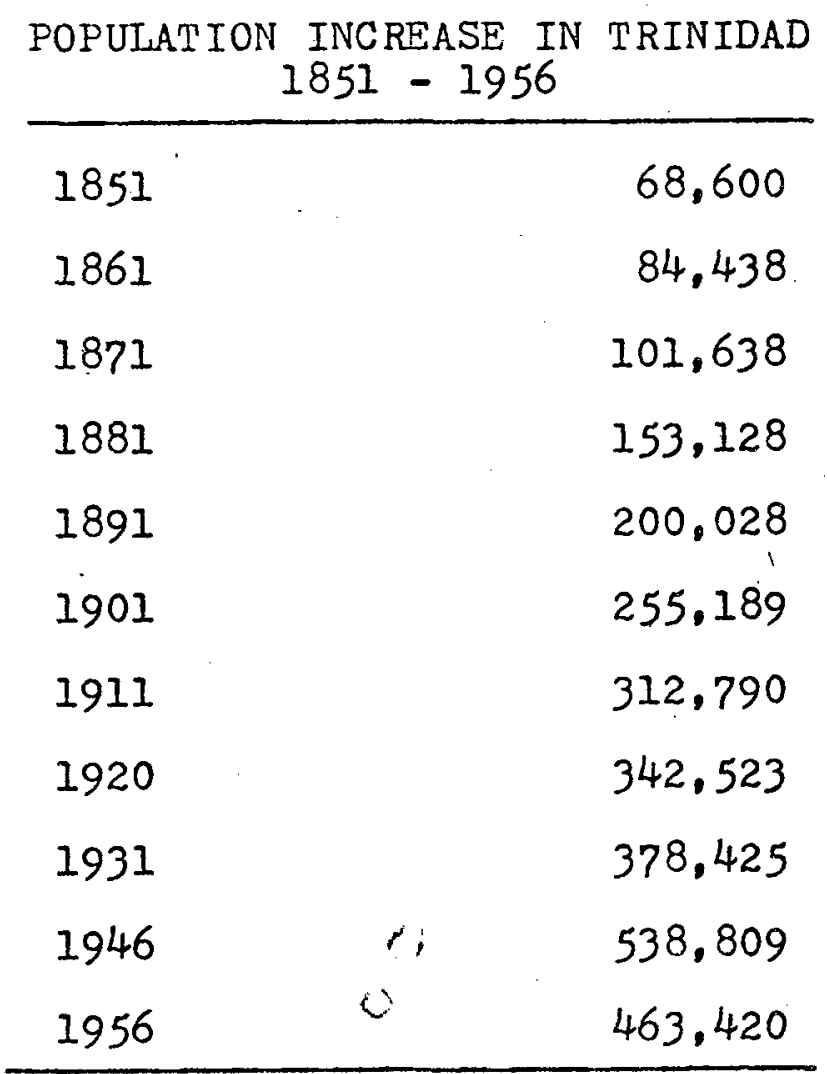

Source: Census Reports of Trinidad from 1851 - 1956 in Gooding, 1961 p. 13.

The population of Trinidad and Tobago according to the last official post censual estimate was 1,020,550 of which 42 percent were less than 15 years of age and 62 percent were less than 25 years of age. It was estimated in 1965 that the unemployed in the age group 15 to 24 constituted 58 percent of the total unemployed of the population (National Task Force on Youth, Report 11, 1973, p. 10).

\section{Changes in Values and Aspirations}

Assumptions made about values in a society are among the most important for the implementing of ideas on education. 
What is considered as worthwhile or important will continually guide educational practice and color attitudes and aspirations. In 19th century Trinidad, the salient features of the society were (1) the political relation of the colony to the metropolitan power, (2) the relation of each of the sub-groups to the dominant class and to one another, (3) the role of the churches, (4) the plurality of culture resulting from the mixture of the population. In the Imperial view, Trinidad was destined to be a sugar colony (Williams, 1962, p. 75, 90) and legislation in the post-emancipation period was passed to exclude the small cultivator.

There were also misgivings among the planters about educating the children of the lower ranks when the need was seen of absorbing the ex-slaves into a free society. The Negroes naturally cherished their new found freedom and worked on the estates when it suited them to do so. Noreover, the experiences of slavery made them correlate estate labor with the slave status. The attitudes of the Indians were of a different nature.

East Indian indentured workers at the beginning kept their children away from the schools for fear of proselytism and Negro prejudice.

They appeared to be unconcerned about education for their children. One missionary among the East Indians (Grant, 1923, p. 82) expresses the view that there was a lack of appreciation of education on the part of parents and children. They seemed to have no outlook or prospect for the 
future either in Trinidad or India except to be the "children of toil." Yet by 1909 the Immigration Department of Trinidad was able to declare "we have now in practice and work here, clergymen, lawyers, solicitors, merchants, shopkeepers, proprietors, managers, overseers, bookkeepers, and tradesmen some of whom came to Trinidad under indenture, the rest of whom had indentured fathers (Augier et al., 1964, p. 210)." Though the intermediate colored class were well favored as individuals, they lacked economic and political influence as a class. They would not desire to be socially classed with the blacks and could not obtain parity of status with the upper class white European (Rubin and Zavalloni, 1969, p. 23).

In the view of Beckford (1972, p. 63) the effect of this social structure was to cause the lower classes especially black and colored to be socialized toward the culture of the dominant class, since their own African cultures were almost completely eroded in the transplantation process into the Western Hemisphere. The British colonial service emphasized political, rather than social or cultural efficiency (Lewis, 1968, p. 87). Its personnel was administratively strong but scientifically and technologically weak. This researcher sees here the influence of the concepts of individualism and privatism of the utilitarianism of the 19th century England.

Consequently many subordinate clerical jobs in the civil service as well as legal and medical positions came to 
be increasingly held by persons from the colored middle class. When, therefore, provision was made for secondary education after the mid-19th century it did not cater for the needs of lower class children. "For the rest of the 19th century society was largely content with provision of secondary education for the middle class, with those who could afford it joining the upper class in sending their children to England (Brathwaite, 1958, p. 15)."

Education implies not only instruction in certain courses but alsc the broader timeless features of morals and religious training. The prominent place of the churches in education, therefore, had prevented the institution of a purely secular system of State schools at the elementary and secondary levels and had led to a dual system of control which became increasingly centered in the religious denominations (Triennial Survey, 1959, pp. 7, 8). But as the people of the country aspired toward representative government and selfrule in the 20th century it became more and more clear that the State would have to take over greater financial responsibility for education and effect centralization in the government instead of in the churches (Noyme, 1945, pp. 31, 93).

Particularistic interests of the various cultural groups and institutions which were a legacy of slavery and the plantation did not contribute to the development of a sense of community or national consciousness. This absence of universally accepted cultural values in Trinidad and Tobago in the pre-independence period was vividly portrayed 
by a Trinidad East Indian intellectual (Naipaul, 1962) whom we have already cited.

Efforts were made to achieve the structure of nationhood, and are still being made to effect a maturity of the spirit of unity. Whereas in the colonial period the people looked to the metropolis for their values, curriculum development and education are now "geared to counteract the constant external pressures from some of the developed countries (Working Party, 1972, p. 6)." The country is fully aware of the pluralistic nature of the society. Curriculum development is being "aimed at producing national unity and not division (Ibid.)." For over 100 years the principal objective of the secondary school has been externally oriented, but, however sound the range of courses may be it is now recognized that the syllabuses leading to the General Certificate of Education (G.C.E.) have been based on very different principles from those which must guide the country's program of popular education. The traditional courses lead to tests of knowledge planned to be a foundation for further work in the same subjects at Advanced Level of the G.C.E. and then at university level. But the great majority of the students need instead an education which is a preparation for life in society or for other types of education. 
SUMIMARY

The population of British Trinidad was made up of a variety of peoples who entered the country during the early years of its history. This has resulted in a diversity of cultures, classes and racial types in a society that was ariginally divided by ascriptions of race and color. The society is therefore regarded as pluralistic.

A numerical sex imbalance developed from the inflow of people, both slave and free. The heterosexual adjustment needs of estates and plantations produced in the course of time intermediate hybrid types, and introduced a culture of unstable extra-legal marital relations.

The demands of the plantation maintained an unintegrated type of community relationships not conducive to fostering national unity.

Failure of the ex-slaves to supply all the labor requirements of the planters, problems of the world sugar market, and the British establishing of free trade produced economic problems for the sugar cane plantations.

In the view of the planters, unfree labor was necessary for plantation work, so that alternate supplies of labor were demanded and supplied through immigration and indenture in competition with indigenous Negro labor.

The concern of many planters for the profitability of their industry in an age of laissez faire could not permit 
them to take much interest in the educational development of laborers nor in their general well-being as persons.

Royal Commissioners to the island saw that the fluctuations of the single-crop sugar industry pointed to the need for a viable economy to be obtained by diversification of agriculture and the settling of laborers on the land as peasant farmers.

A culture of dependency persisted with the continuation of the plantation system, which did not cater for the educational or social development of the lower classes.

The colored middle class were able to attain to clerical jobs, teaching, and some of the professions, but neither colored nor Negro were taught managerial skills, which were the preserve of the upper classes.

The Imperial interest in education was not consonant with its support of the plantation economy.

Education came to be dispensed also differentially according to race and color ascriptions.

Because of strong vested interests, social distance also characterized employer-employee relations, which were not bridged by any associations or agencies for negotiation.

The cost of immigration and indenture for the support of the sugar industry were partly met from public monies which were diverted from greatly needed public services.

Low wages, inequitable taxation, and depressed living conditions were the legacy of the poorer classes up to the Second World War. 
The unnatural increase of population caused by immigration and settling of East Indians--who are also a high fertility race--resulted in a high rate of population increase when the death rate was lowered by reason of improved health services in the 20 th century.

The large increase in child population since the mid-century will demand large educational budgets even beyond the nation's resources, and pose problems of employment.

The 19th-century European social values conditioned the political relations of the Crown Colony, the social distance between the classes, and the leading role of the churches in education.

As the power of government was placed progressively more into the hands of the indigenous people, government assumed more and more responsibility for education.

The former colonial particularism is giving way to a sense of community and national consciousness.

Educational values were once accepted from the metropolis, and the curriculum was externally oriented, Now, curricula are being structured to meet the life needs of the students and are geared to producing national unity. 
CHAPTER V

SORE ASPECTS OF THE CROWN COLONY GOVERNNENT

IN RELATION TO EDUCATION

The relation of the social and economic factors in the country's educational system were discussed in Chapter IV. There are so intimately connected to the political state of affairs that obtains in a country's development that attention must be given to the interplay of education and politics in the history of Trinidad and Tobago. The direction of government policy appears to be the greatest force producing educational changes. King (1969) states:

Schools do as little or as much of the whole work of education as society or the state permits, requires, or encourages.. . What makes or mars education is the social or cultural context with traditions and susceptibilities reaching far back. . (p. 4).

\section{Origin and Structure of the Crown Colony}

Local government in the old West Indian colonies was different from that of the Spanish system established in Trinidad before its conquest by the British in 1797. The Spanish governors of Trinidad held autocratic powers limited only by the audiencia ${ }^{*}$ in Caracas and the residencia held on the expiration of the governor's term of office.

* See Appendix D 
The Cabildo* or Municipal Council of Port-of-Spain also possessed some influence in the government. After the capture of Trinidad, the British retained a semblance of the Spanish system for some years, thus laying the foundation for strong central government. There was, however, no effective local government (Parry \& Sherlock, 1956, p. 206).

Following the abolition of the slave trade by the British, there was much administrative discussion about the status of the government in Trinidad. Lord Liverpool's communication to Governor Hislop in November, 1810 indicated why representative government was not, in his view, a feasible type of administration for the new colony (Gt. Britain, 1810-1811 [184], vol. xi, pp. 333-335).

The circumstances in the island of Trinidad were so materially different from those in other colonies, that the same type of government administration could not apply. The people of color formed a great majority of the free inhabitants. It was impracticable for popular government to be established in Trinidad for the first time while excluding that people from all political rights and privileges. The spirit of the capitulation guaranteed that their status was not to deteriorate from that which they had enjoyed under the Spanish government. Further, the white population of the island consisted of a mixture of people of various nations who were unacquainted with anything like the principles of the British Constitution. Then, the abolition of the

* See Appendix D 
slave trade had placed upon the government the necessity of retaining such powers as would make abolition a reality. It was also the concern of the Imperial Government, as a result of previous colonial experiences, that there should not be conflicting relations between Parliament and the subordinate legislatures.

The Fait Accompli of Crown Colony

The governor was informed in the imperial reply that it was to be considered a point determined that it was not advisable to establish in Trinidad any independent legislature. The Imperial power would be delegated to the governor as the King's representative, whose acts would always be subject to being revised, altered or revoked by His Majesty himse If (Ibid.).

Just before the Act of Emancipation, further colonial correspondence clarified the issue about the colonial legislature and justified the structure of the Crown Colony government on the basis of the variety of social classes and races that comprised the population (Gt. Brit., C.0, 296/10, 1831).

It will be sufficient to state that, as society is at present constituted in the island, His Majesty's ministers will abstain from advising the introduction of a Representative Assembly and popular elections. For the present it is intended that you should be assisted by a Council with whose concurrence it will be in your power to legislate on every subject of internal policy.. (Goderich to Grant, pp. 1, 2)

The Crown Colony with its nominated (appointed) legislature thus finally took shape and was destined to 
retain. this form for nearly 100 years. Its avowed rationale at that time may be summarized as follows: of color

(1) To protect the privileges of the free people

(2) To prevent domination by the more numerous non-British whites

(3) To prevent any recrudescence of procedures related to slave trading

(4) To maintain harmonious relations between the Imperial Parliament and the subordinate legislature.

\section{Concepts of State Responsibility for Education and Social Legislation}

Among the needs for the progress of a society $G$. I. Beckford (1973, p. 203), a contemporary West Indian economist, includes the development of an educational system designed to promote national consciousness, the productive ability of the people, and to provide a structure for fulfillment of individual aspirations. This thesis finds support in current literature (UNESCO, 1970, pp. 85-126; Saylor \& Alexander, 1974, pp. 102-140).

The post-emancipation society was unable to provide such a system, for one of the principal problems then was, how to give full freedom for development of the ex-slaves and yet retain their regular application of themselves to the interests of the planters. This same ambivalence is found in the colonial correspondence and administration of the period. For example, an important feature of Lord Grey's colonial policy was education. He had the firm conviction that the welfare of the emancipated people should not be left 
to time or the missionary societies, but should be the active concern of the Imperial Government. (Morrell, 1930, p. 269). Yet, one of the first pronouncements on the purpose of education in the period was Grey's proposal to Harris that the people should "look to labor on the estates as their main dependence." To facilitate this objective, he urged that schools should be set up with an industrially oriented curriculum so as to encourage a love of employment (Parry \& Sherlock, 1956, p. 247). Harris' more liberal views were that British policy should not only free a race but form a society. He therefore proposed his educational plan for training teachers, for free schools financed out of local rates, and free secondary education for those who showed fitness for that level of schooling (Williams, 1962, pp. 199-203). Emancipation had thus far physically freed the slaves, had compensated the planters, and apprenticeship had provided a brief period of transition which was used for a continuance of the serf relationship and not in preparation for the demands of citizenship. As Harris expressed (Gt. Brit., C.0. 295. Vol. 162, Harris to Grey, 1848):

One of the many errors which have been committed since the granting of apprenticeship is the little attention paid to any legislation having for its end the formation of a society on true, sound and lasting principles. . . . As the question now stands, a race has been freed but a society has not been formed (Simey, 1946, p. 65).

To Harris it seemed that the highest concern of the legislature had been the formation of laws for the control 
of the population with a view to ensuring the greatest return of sugar for the capital invested in the "large English speculation (Wood, 1968, p. 220)." Yet he was in agreement with Lord Grey that "the highest interest of the Negroes requires that the cultivation of sugar should not be abandoned. . (Augier et al., 1964, p. 201)." He felt that the authority of the law should be exercised and that the Executive should have more scope for humanizing the people. To this end, he was in favor of adopting "an expensive system of education," and that it should be assisted by the easy circumstances of a superior class of Europeans amongst the population (Biatheison, 1936, pp. 87, 88).

Harris's philosophy is at once seen to have been revolutionary when it is recalled that the British education movement was just receiving its impetus at a time when the principle of state responsibility for the education of the youth was not yet established, the idea being that education was the province of the home, the church and private concerns. It was in these circumstances that Governor Harris, before the Legislative Council of Trinidad, made his comprehensive statement expressing his philosophy of education:

Education has to do with the whole constitution of man; his religious convictions, his moral sentiments, his intellectual capacity, even his physical powers, must be affected by it. It should be confined neither by place nor by time; it must be if not neglected ever going on so long as life continues: but instruction has reference more to the cultivation of the intellect. With some of the departments of the former, the government does not interfere, but it has a right to require that its citizens should not continue in ignorance, in 
order that the State may not suffer from the vices and errors which ignorance is likely to induce (Wood, 1968, p. 222).

\section{$\frac{\text { Dichotomy of Plantation Development }}{\text { and Social Development }}$}

The plantation has been used for hundred of years as an instrument of colonization. Colonization sought to bring territory and people under external forms of control in order to facilitate the exploitation of natural resources for the benefit of the overseas trade of a metropolitan power. Thus several European peoples, after the period of discover, started extensive campaigns of colonial expansion. Where metropolitan labor was insufficient or inefficient, and indigenous people were intractable, immigrant laborers were brought in. This resulted in the racial, cultural and sex composition of the population with rigid stratification of the social structure, cultural plurality, absence of upward mobility, and the dispensing of educational opportunity on the basis of ascriptions of race and color.

The social structure of the plantation society had to be maintained according to the social organization necessary for profitable production (Beckford, 1973, pp. 40, 62); nence the low wages and poor living conditions of laborers in an age when laissez faire was "established as the dominant social philosophy in the Victorian age (Moyne, 1945. p. 7)." The view is therefore highly warranted that legislation could not "at one and the same time seek to maximize the profitability of plantation production and the welfare 
of plantation labor (Beckford, 1972, p. 40)." If the situation in Trinidad at that time is viewed critically, it will be seen that there was a functioning of this theory in the efforts to provide education. The social scientists Rubin and Zavalloni (1969) also argue this point:

The spread of education would have been a threat to both the ideological and economic underpinnings of the institution of slavery. After emancipation it became clear that extensive education was equal.ly incompatible with the indenture system. The plantation, whether under slavery or indenture required a large, stable and cheap labor force, Education of the workers and their children was not consonant with the fundamental requirement (pp. 35, 36).

\section{Educational Prerogative in the Crown Colony}

The question of prerogative of education in Trinidad and Tobago must be considered in reference to time and the structure of society. The current demands for equality of access to education, especially at the secondary level, are a feature of the 20th century ethics in education. Such principles, in the mid-19th century were just being enunciated as theories by imperial administrators in a milieu and at a period in which the wealthy were expected, as of right, to be educated differently from the poor; when popular education was not yet, as we have stated, a recognized function of the State; when the "lower orders" were expected to keep the status that was ordained for them by Providence; when philosophers were still uncertain of the role of the Negro in Society, whether he were educable or not, whether he were capable of being christianized (Ibid., p. 34). 
Though there was no popular education under slavery, some slave schools were provided by the missionaries and a few owners of slaves (Gordon, 1963, p. 14).

In Port-of-Spain in 1823 and 1826, two national schools were started for "twelve free-born boys" and "twelve free-born girls" respectively, white and colored (ottley, 1962, p. 57), for the benefit of the poorer class who could not send their children to England. The School Board was not in agreement with Governor Woodford that slave children should be allowed to attend the national schools, so that the unfree status limited the enrollment in the schools (Ibid., p. 60).

Emancipation introduced the Negro Education Grant and moral and religious education which prospered for a few years before it declined with the termination of the grant.

It presents a problem to justify the right of popular education in the post-emancipation years when one considers, as Gordon (1963) affirms, that "there was seldom a coherent idea of what public education was for beyond establishing a limited personal status for a minority (p, 6)." Was the society prepared to accept educated Negroes and Indians? What roles could they play in their environment? The conflict of ideologies loomed large.

The planters had misgivings about the consequences of education for the lower classes, since discontent and aversion to agriculture might be instilled in people whose role in life was manual labor. The industry might be ruined 
as one planter declared as late as 1926 (Williams, 1962, p. 215). The religious leaders and the British and Foreign Anti-Slavery Society kept a watful eye for any legislation intended to introduce education for plantation work, as they thought, under the guise of industrial education (Norrell, 1930, pp. 241, 242). The impulse for universal education, in the light of modern educational planning and research, was inhibited by the need to develop the country socially and economically and so raise the standard of living.

Until the National Government of Trinidad and Tobago, as it stood on the threshold of independence, made its commitment to the principle of "free secondary education for all," the prerogative of secondary education was held by a small minority and was entirely based on wealth or the ability to win "exhibitions," "places," or scholarships.

\section{The Search for Constitutional Reform}

In many countries of the world, the population consists of a mixture of various ethnic groups. This plurality of racial and cultural features is an outstanding characteristic of Trinidad and Tobago. Joined to this are the political; social and economic strictures to which the country has been subjected during its history. These resulted in an individualistic political climbing not conducive to building national consciousness. Williams (1962, p. 283) says of this unhealthy striving that the political parties, the trade unions, the professions were all "riddled with individualism. Each seeks aggrandizement at the expense of his neighbour, 
giving rise to attitudes that threaten equality of opportunity and jeopardize political democracy (Ibid.)." Any decisions of national scope such as reform or financing of education, must be carried through by laws or government administrative procedures and are therefore political acts. Educational development must go hand in hand with political progress which is best expressed in national or community solidarity.

The community structure, then, must include a reserve of men and women who are suitably educated, responsible, and therefore qualified for administration of public services and capable of advising political leaders in the formulation and implementation of policy. Much of this education and training at the higher level must be accessible within the environment. To what extent could Crown Colony structure promote such development?

As early as the $1840^{\prime} \mathrm{s}$, Governor McLeod recognized the need of a universal system of education for the country:

There is perhaps no British colony, where, from the mixed nature of its inhabitants... the necessity of some general plan of education is more needed than in Trinidad. The number of immigrants we are receiving renders the demand of an extension of the means of education of greater consequence (Gordon, 1963, p. 47).

Yet, for over a century, the education provided at the secondary level catered to the desires mainly of the upper and middle classes. One of the contributory causes was that the supremacy of the European cultural values and symbols in the society produced feelings of racial and social 
inferiority that led members of the developing middle class

to emulate the upper class so that their nationalist interests

found expression in the desire to obtain identity and equality of treatment with Europeans. Rather than develop a cultural life of their own, they sought a passive absorption in the European cultural traditions. This was a factor immeasurably complicated by the absence of an indigenous tradition; and when West Indian nationalism did develop and began searching for distinctive symbols, there were few to be found. These were largely to be discovered in the lower class or "folk" culture rather than in an intellectual tradition (Brathwaite, 1958, p. 54, 55).

The desire for constitutional reform, however, was not extinguished. In the post-emancipation period, there were conflicting views about the appropriateness of popular franchise. James Stephen of the Colonial Office and the Abolitionist Missionaries, out of consideration for the exslaves were opposed to the franchise. Stephen wrote in 1841 (Williams, 1955): "Popular franchises in the hands of the masters of a great body of slaves were the worst instruments of tyranny which were yet forged for oppression of mankind (p. 4)." The Governor of Jamaica, Lord Elgin, later Governor-General of Canada, viewed the issue dispassionately. In 1844, he communicated his views to the Secretary of State:

I think that a popular representative system is perhaps, the best expedient that can be devised for blending into one harmonious whole a community composed of diverse races and colors. . . In colonies which have no Assemblies, it would appear that aspiring intellects have not the same opportunity of finding their level, and pent up ambitions lack vent (Ibid.).

The Colonial office, on the basis of its fait accompli in regard to Trinidad, rejected Elgin's view. 
Various British intellectuals such as Trollope, Carlyle, and Froude could not conceive of parity of status for blacks and Europeans. Thus, it appears, intellectual snobbery and Colonial office disregard for local opinion formed the background for Trinidad's search for representative government for 100 years.

The liberal Governor Lord Harris was the first to advocate constitutional reform. He made repeated attempts to get an elected element into the Legislative Council. He was concerned about following a middle of the road policy (Williams, 1955):

Either by restricting the franchise too much, legislation may be delivered over to an oligarchy in the shape of a mercantile plantocracy, or, on the other hand, by not having sufficient checks, it may be commanded by a half civilized and uneducated populace liable to the sudden excitements and fluctuations of such masses in which the antipathies of class would be increased by those of color ( $p$ p. 7,8$)$.

Another effort was made through 5,000 people of Trinidad who signed a petition in July, 1887 proposing (Ibid),

I. That the system of government which now obtains in this Colony is no longer adapted to the requirements and aspirations of its inhabitants...

2. That the material and intellectual progress of the Colony since 1850 entitles the taxpayers to have a voice in its legislation and some control over its taxation and expenditure . . . (Ibid.)

The Imperial response was a Royal Commission in 1888 to consider the possibility of the franchise and election of half the membership of the Council. The Commission saw an unprecedented demonstration of West Indians, English residents, all colors, races and religions for constitutional 
reform.

With the support of the Attorney General, who rightly or wrongly, claimed that there was a lack of adequate knowledge and education among a representative cross-section of the population, the Colonial office remained adamant in its refusal to grant any degree of representative government to Trinidad, claiming that it was necessary to maintain the stability of the country and not alienate investors.

Three changes in Trinidad concurred to intensify the demand for constitutional reform after the First World War. They were (1) the discovery of oil in commercial quantities, (2) the abolition of Indian indenture, (3) the emergence of the Working Class Movement.

In 1903. Chamberlain had again reaffirmed the importance of Crown Colony Government for Trinidad and Tobago. Upon the emergence of the new interest in 1921, E. F. L. Wood, Parliamentary Under-Secretary of State for The Colonies, was commissioned to visit the West Indies and British Guyana (Williams, 1962, 216). Wajor Wood encountered different points of view (Oxaal, 1968, p. 51):

1) Propertied East Indians; the Chamber of Commerce, and the Agricultural Society (representing the planters) opposed any change.

2) Another Indian faction, the East Indian National Congress, desired representation for the East Indian Community.

3) The third group, the Legislative Reform Committee, 
opposed communal representation as being divisive, and advocated instead simply an elected section of the Legislative Council.

Iiajor Wood opposed responsible government as being premature. He saw the diversity of the population, the backwardness of large sections, the absence of a leisured class, the need for uniformity of administration in the various colonies, and the necessarily small representation in those colonies as factors militating against successful popular government. An oligarchy might be entrenched in power to their own benefit instead of that of the whole community (Williams, 1962, pp. 218-220). Wood found that the demand for increased representation was irresistible. He suggested introducing elected members into the Legislative Council by reducing the number of the nominated majority, recommended the creation of a majority of nominated nonofficials and elected members.

Effective from 1924, Iimited suffrage on the basis of property and income qualification was granted. For the first time in the history of the colony elected members were introduced into the Legislative Council (Malik, 1971, pp. 72, 73).

Foremost in the quest for constitutional reform was Captain A. A. Cipriani, a French creole, who had identified himself with. the working class, and worked for West Indian federation and the betterment of the working people. After 127 years of Imperial rule, the country began 
to make progress from the pure form of the Crown Colony government toward full responsible status. But the economic depression of the 1930s, made worse by the low world prices of sugar and the distressing social conditions we have already described, led to growing social unrest and the demand from the people in several West Indian colonies for constitutional and social reform, and culminated in tragic civil disturbances in Trinidad in 1937.

A Trinidad Disturbances Commission was appointed the same year. The following year, another commission, The West India Royal Commission, under the chairmanship of Iord Moyne, was commanded to investigate conditions in the area. The Moyne Commissioners regarded it as imperative for the people of the West Indies to play a greater part in the government and administration of their territories and were in favor of an extension of the franchise.

Owing to the exigencies of World War II, the Moyme Commission did not submit its comprehensive report until 1945. It was in the spirit of the Report that $\operatorname{Mr}$. Creech Jones in the House of Commons on July 8th, 1948 declared (Burn, 1951): "We are in those territories to guide them as quickly as possible circumstances permit to responsible government with in the Commonwealth (p. 169)." This was in keeping with the statement made by his predecessor in the Colonial Secretaryship, Mr. Stanley (Ibid.): "The declared aim of British policy is to quicken the progress of all colonial peoples towards the ultimate goal of self-government." 
He went on to say, however, that self-government must rest upon firm economic and social foundations.

The tardiness of colonial peoples in Trinidad and other West Indian islands in attaining to responsible government should not be regarded as an indication of the people's inability to govern themselves. It may rather be seen, as a recent researcher (Rodman, 1971, p. 23) believes, as a reflection of a metropolitan effort to preserve cherished advantages. The acceleration of progress toward self-government when there is a threat of alienation from the local people is an assumption which appears to find justification in the experience of Trinidad and Tobago as in other West Indian territories.

It was the need for this concerted action that Cipriani sought to impress upon the working people. Community of purpose and popular education were vital for effective participation in the country's development as he indicated to them before the West Indian Conference in Dominica in October, 1932 (Gordon, 1963):

Working men and women, I say tonight your greatest asset lies in education, and you must struggle and fight on and on, until you are the means of introducing compulsory education in every one of these colonies, and . . you must never cease fighting until your children enjoy the same privileges of education in your schools as the children of the multi-millionaires. You will ask, how is that to be accomplished? It is to be accomplished by your standing together, and by your weight of numbers which is the greatest weapon that you can wield. honey you have none, influence none, but you have that one asset which is your weight of numbers; and mind you, if you do not make it felt, then the fault is at your 
door (p. 165).

In the face of opposition from planters, regulations for compulsory education were not passed in Trinidad and Tobago by the Legislature before 1935 (T. \& T. Education Dept., Triennial Survey, p. 12).

As the struggle for constitutional reform proceeded, full adult suffrage was attained in 1945. This was followed by rapid progress toward responsible government in the postwar years. Social and political advances were being achieved dramatically by the 1950s, for the new constitution indicated a recognition of the movement toward self-govemment. The Legislative Council ceased to be an advisory body and became the chief agency of policy making with a majority of elected members, and a ministerial system. Now that the Crown Colony system with its social and political strictures was on its way out there was a surging of nationalist sentiment.

The Minority Report on Constitutional Reform stated (Williams, 1962): "Under such a constitution the broad masses of the people can at last realize that this is their country (p. 241)." Some of the basic problems of the pluralistic society were being attacked. A frinister of Education was appointed and provision of secondary education was increased steadily during the 1950s, The changes in the constitution were reflected in improvements in housing, health services, roads, water, electricity, etc., and the idea was beginning to be realized that it was possible for 
the "broad masses of the people" to "enjoy the privilege of education."

By 1956, when the People's National Movement won the general elections, the monolithic erudition of Dr. Eric Williams with his country-wide adult education program and his lectures at the University of Woodford Square--a school without walls--had lifted the minds of the populace to an advanced level of learning in the course of several months. The ignorance of colonial times had been dispelled for good.

The special circumstances in the Crown Colony of Trinidad are regarded by some colonial writers (Augier et al., 1969, pp. 218, 219) to have favored the proper administration of the Colony, since the governors did not have to await the pleasure of the Assembly to vote funds or pass laws. However, the expedient of dispensing entirely with the representative assembly in favor of the pure form of the Crown Colony with a view to securing the interests of the unrepresented masses may be called into question.

On the admission of West Indian governors such as Lord Harris, and of the Commissions of 1897, 1937, 1938, the economic system of the plantation, which received Imperial support, tended to maintain an educational and social status of the majority of the population that facilitated the interests of the planter class. As Williams (1963) says, "The Crown Colony needed only sugar workers; it did not need citizens (pp. 213-215)." 


\section{SUMHARY}

The Crown Colony of Trinidad differed from the older British West Indian colony which was governed by a Representative Assembly presided over the by Governor. In the Crown Colony the local Legislative Council, appointed by the Governor, functioned only in an advisory capacity, so that the Imperial Government held complete political control.

Ostensibly, the raison d'etre of this new administrative device in the West Indies was laid down by Imperial fiat on the need to protect the privileges of the masses, to prevent non-English domination, to prevent any revival of slave trading, and to preserve harmonious relations between the colony and the Crown.

In the post-emancipation period, the Trinidad Council was obviously not much concerned with developing a society, but rather with the enterprise of sugar production.

Lord Harris' balanced program of development included the maintenance of the plantation and positive measures being taken for the organization of a viable society in which a program of education would play a leading role. The social structure of the plantation in an age of laissez faire was not compatible with the idea of education and social reconstruction.

Though a few schools were started with the support of the State, popular education was not at that time regarded either in England or in Trinidad as the province of 
the government, and the purposes of public education were usually not coherent. Harris program of education was initiated many years in advance of education planning even in England.

The planters usually saw in popular education only the ruin of the country's agriculture.

The prerogative of secondary education was based on wealth or exceptional ability to compete for places.

Notwithstanding the Imperial fiat of the Crown Colony appeals for constitutional reform were made by governors and people from the mid-19th century.

The Imperial response stressed the need for political stability, an educated and truly representative body, and the fear of alienating investors.

The first constitutional change was made in 1924. But social conditions were still static and secondary education was still the privilege of the few.

Depressed social and economic conditions in the 1930 accompanied by a series of civil disturbances indicated a crying need for a change of the status quo.

The Imperial Government announced its policy directed toward leading West Indian colonies to self rule, and dramatic progress was made in this direction. Adult suffrage was achieved in 1945.

The greatest changes toward self-government were made under the leadership of Dr. Eric Williams with his organized strategy of social and political education. 
The view is held by some West' Indian writers that the prolonged political stagnation of the country under Crown Colony status was an expedient of the metropolitan power to preserve to itself certain advantages. With the advance toward responsible government there was a great increase in national sentiment and in access to secondary and higher education. 
CHAPTER VI

STATE AND DENOIINATIONAI PROVISION

OF EDUCATION

\section{Early Educational Thought that Influenced Education in Trinidad and Tobago}

During the first half of the 19th century there grew up in Trinidad an awareness of the need for education and attitudes toward its development which appear to have been a reflection of the conflict of ideas current in England at that time in regard to popular education.

In the early 18th century education for the few of the poor who received it was given in dame schools and charity schools run by the Society for the Propagation of Christian Knowledge. A different schooling, which went beyond the three $R s$, and moral and religious education was available for the sons of the wealthier classes in grammar schools which had been endowed for centuries. The more significant of these were the famous English "Public Schools (Cramer \& Brown, 1965, p. 62)."

Later in the 18th century, Robert Raikes began the Sunday school movement in England for the benefit of the "Iittle heathen of the neighborhood," and in the early 19th century John Pounds, a cobbler, started "ragged schools" for destitute children (Ibid.). Already in the latter 18 th 
century Adam Smith $(17 / 6)$ in his. "Wealth of Nations" had advocated the teaching of the three Rs and physical occupation to "almost the whole body of people". . "For avery small expense (Curtis \& Boultwood, 1966, p. 44)."

Lancaster's monitorial system, by the year 1808, had attracted a great deal of attention. In 1807 samuel initebread, in the House of Comnons introduced a bill for pcpular education (Ibid., pp. 50, 51) which would provide two years schooling for all children between the ages of seven and fourteen. This progressive bill was opposed by both conservative members and the Church of England. The Church, it would seem, would not have the control of education taken out of her hands. During the House of Commons debate on rhitebread's proposal, Davis Giddy protested (Hansard, Vol. 9, July, 1807):

- . however specious in theory the project might be of giving education to the laboring classes of the poor, it would be prejudicial to their morals and happiness; it would teach them to despise their lot in life, instead of making them good servants in agriculture and other laboring employments. Instead of teaching them subordination it would render them fractious and refractory. . . . It would enable them to read seditious pamphlets, vicicus boolss, and pubJications against Christianity; it would render them insolent to their superiors and in a few years, the legislature would find it necessary to direct the strong arm of power towards them (p. 789).

Similar objections were raised by planters in the Trinidad and Tobazo Legislature over the question of education for laborers' children.

Though Thitebread's proposals were rejected, the 
struggle continued. Among the champions of popular education was J. A. Roebuck (Curtis and Boultwood, 1966) who in 1833 proposed a compulsory scheme of education on conditions which were later repealed in the West Indian scene by the Committee on Education in Trinidad, 1889. The interest raised in education for the masses drew petitions from all over Britain. The result was that a sum of $\$ 20,000$ was allotted to two voluntary societies "in aid of Private Subscriptions for the Erection of School Houses for the Education of the Children of the Poorer Classes in Great Britain (Ibid.)." This grant coincided with the provision by the Imperial Government of \$30,000 for the education of ex-slaves in Trinidad and other colonies. As these grants were increased in Britain the work of the voluntary societies was extended and finally became too complex for them to handle. The outgrowth of this was the birth of the dual system including the provision of "board schools" and "voluntary schools." This measure was also reflected in Trinidad by the establishment of its Dual System in the same year.

In England, before 1902, secondary education was mainly the privilege of children whose parents could afford to pay for it. The view that education beyond the elementary level should be open to all pupils who could benefit from it was gaining ground and led finally to the Act of 1902 that gave the power to the new Local Education Authorities to provide schools other than elementary. That this concept was not a new one is seen in the fact that Lord 
Harris's plan of Primary Ward school, supported by local rates, District schols, and a college for Trinidad, was proposed as early as 1847 , though the society was not jet ready for such advanced ideas.

The Hadow Report introduced the organizational idea of abolishing the "elementary" school arrangement and substituting the "primary" school which would terminate at age eleven or twelve. The period of education following was to be known as "secondary," which would include all forms of post-primary education. The traditional secondary schools were to be named Grammar Schools, and all other types of post primary education would be given in schools which should be known as modern schools (Cramer \& Brown, 1965, pp. $184,185)$. It was this type of school that the MarriottMayhew Commission, 1933, introduced to Trinidad and Tobago. The British Education Act of 1944 was an attempt to unify the piece-meal recommendations and ordinances made through the years. The Act (Education Act, 1944) provides that the child's education should form one continuum in three stages, and that it should continue in his out-of-school experience. This was the organization of education in Trinidad and Tobago later recommended by the Naurice Committee, 1959.

Mr. A. Crossland, 1965, Secretary of State for Education and Science, recommended to the British I.E.A's the government's motion in the house of commons that it was the government's wish that the eleven-plus selection be ter- 
minated, as well as separatism in secondary schools. A comprehensive school arrangement, in one of several forms, was suggested, which might vary according to the needs of the local authorities (Cramer \& Brown, 1965, pp. 445, 446). Trinidad and Tobago Government is committed to the ultimate elimination of the eleven-plus but has not gone so far in its transitional stage as to be able completely to remove separate schools.

\section{Trinidad Schools Before Emancipation}

Apart from the moral and religious education given by the Missionary Societies, there was nothing in the nature of any program or policy of education in Trinidad prior to emancipation. Gordon (1963) mentions that there were, following the Amelioration Ordinance in 1823, an educational ordinance which showed that there were in existence "one English Female Boarding School and three French day schools in Port-of-Spain, comprising 175 scholars, and a small day school, where, however, Spanish only is taught at one of the Indian villages (p. 17)." Another author (Ottley, 1962) mentions the establishing, in this period, of two national schools for "free-born" white and colored children of the poorer classes.

Private Schools

During the 18th and early 19th century, there were several schools in Trinidad operated by private individuals (usually school mistresses) for the instruction of children 
of the wealthy families of European origin. The curriculum comprised mainly the three Rs and elements of proper deportment. This was followed by schooling in Europe (Gooding, History of Education in Trinidad, unpublished Typewritten MS, p. 10).

\section{Enunciation of Flans for popular Education.}

After emancipation, two further efforts were made to provide education. The Cabildo or Town Council organized two schools for boys ( $T \& T$, Historical Development of Ed., 1962, p. 1). There were several thousand apprentices and their children who were in a state of transition to freedom, and for whose mental improvement the British public desired some systematic provision. The Fifth Resolution of the House of Commons, June 1833, had declared (Gordon, 1963a) "that His Majesty be enabled to defray any such expense as he may occur . . In providing upon liberal and comprehensive principles for the religious and moral education of the Negro population to be emancipated (p. 20)."

In harmony with the changing mood and principles of the 19th century in regard to State responsibility for education and with the provisions of the Act of mancipation, the Imperial Government offered $\pm 30,000$ (Ibid., p. 19) for the education of the ex-slaves. Of this Trinidad received E 800 in the first year on the basis of its population of 22,359 slaves.

In 1834, all religious organizations were required to submit a statement of what they were doing in the area 
of education in the West Indian colonies. The Rev. John Sterling, an Anglican parson in St. Kitts was asked to study the papers submitted and make recommendations of policy. He was chosen because of his "practical knowledge of the state of the Negro population and $h$ is knowledge of educational enquiries in England and Europe (Gordon, 1962, p. 145)." Sterling described the state of religious instruction and schooling and made $h$ is report with occasional remarks about the inadequacies of the work of the religious bodies. He saw these as reflections of the same inadequacies to be found in the schools in England at that time, such as untrained teachers, ineffective rote of learning, large classes and unsuitable buildings. He also stated that the government could not undertake the task of education and thus separate the youth from the religious instruction imparted by the various sects to the adults. There was no public department of education, and if operations were carried out through a government commission, the funds of the religious bodies would be withdrawn, and there was little certainty that Parliament would supply the deficiency. Sterling saw the special problem of Government supporting religious instruction in a milieu that was predominantly Catholic. He expressed his misgivings about the pragmatic value of Catholic tenets for promoting social improvement, but understood that it was impracticable for Government to take the education of Roman Catholic Negroes in its own hands and exclude their clergy from interference (Ibid.). 
For education to be of any enduring value, Sterling saw the need for (1) the immediate diffusion of a higher and more mature education than the primary, and (2) the improvement of the quality and extension of the scope of the system of instruction and discipline.

Sterling's recommendation for schools of a higher and more advanced kind than those then in existence was the first enunciation of secondary education in Trinidad. His proposal was "to educate boys of all classes and colors, between 10 and 18 years of age, whose parents could pay, say, one shilling per week for each, but could not find the means of sending them to Europe . . (ibid.)" This comprehensive plan of Sterling's which is at once seen to have been idealistic, was to include the children of all classes, from the "mere field laborers and lowest artisans, and the wealthier planters, merchants, and members of professions (ibid.)." The curriculum was to include reading, writing, arithmetic, bookkeeping, English, history, geography, and some rudiments of natural history, natural philosophy, and mathematics. The masters were to be selected for their moral and religious excellence, yet the school was not to be a religious school; it was not to have any ecclesiastical superintendence.

Sterling's programme for higher learning was evidently too complex to be put into effect, and was not realized under the Negro Education Grant, but the duality of interest in educational matters which he stressed was 
destined to become an important factor in the country's educational policies.

\section{The Contribution of the Missionary Societies to Education The Mico Charity*}

For the implementation of the Negro Education Grant, the religious bodies, during the first two years, were invited to extend their programs of school building: They were offered two-thirds of the costs of buildings if they provided the rest. The Mico Charity was invited to contribute by providing schools and normal schools for the training of native teachers (Gordon, 1963, pp. 23-27).

During the period of the Grant, the Mico Charity was foremost in the provision of funds. Among the many schools they built throughout the west Indies, some were built in Diego Martin and South Naparima in Trinidad, among the apprentice population. Their efforts were especially appreciated by the British Government, especially in predominantly Catholic islands like Trinidad, where they conducted non-denominational schools which the Catholic Church did not object to having their children attend.

In 1838, the Mico Trustee reported that there were in operation in Port-of-Spain, five schools, including one for boys, one for girls, one for infants, and one for adults, with a total enrollment of 710 pupils, and a normal school provided for the training of local teachers (Gooding, History, unpublished MS., p. 12).

See Appendix E 
After two years of operation under the Grant, most of the religious bodies found that the large recurrent expenses involved in the operation of the schools were beyond their resources. They declined to construct more schools, and requested that the Grant be allocated to defray twothirds of the expenditure on salaries. This they considered essential if they were to obtain competent qualified teachers (Gordon, 1963a, pp. 34, 35).

Termination of the Negro Education Grant

To the Imperial Government, it was becoming more and more evident that the Church-State arrangement would not result in the establishment of the system of education that was envisaged for the West Indian colonies. By 1841 , the Imperial Government announced the termination of the Grant, which finally became effective from 1845. The West Indian legislatures and workers were called upon to provide financial support for their own programs of education (Gordon, 1963a, p. 42).

\section{Governor Mcleod's Education Plans}

In Trinidad, during the $1840 \mathrm{~s}$, the implementation of a plan of popular education involved peculiar circumstances, which were destined to affect the progress of education for a long time. In no other West Indian colony was there such a heterogeneous and unintegrated collection of peoples and cultures. In addition to the variety of religions, there was a variety of languages: French, Spanish, 
French-Creole, and English, and with the later immigration of East Indians the variety was increased.

In his communication to the Secretary of State, Governor licleod expressed his awareness of the urgent need for a system of universal education, and outlined his argument in a proposal he presented (Gordon, 1963):

There is perhaps no British colony, where, from the mixed nature of its inhabitants.. . the necessity of some general plan of education is more required than in Trinidad. The number of immigrants we are receiving renders the demand of an extension of the means of education of greater consequence every day ( $p, 47)$.

Mcleod saw the system in effect in Ireland as a ready-made solution. Education could be advanced and the English culture and language disseminated. A new system of national education had been instituted in Ireland in order to countermand sectarian rivalry. A Government Board of Education had been set up, teaching was secular, but Catholic and Protestant clergy gave religious instruction in the school building one day in the week to children of their faith. Textbooks were specially prepared for a non-sectarian program, and the teachers specially trained for the purpose in Normal Schools that were among the best in Europe. Noral training was ethical rather than doctrinal, and all instruction was given in English, and not in Irish, in a country of eight and a half million Irish, and two million English (Gordon, 1963, p. 47; Wood, 1968, p. 216).

In Trinidad there were mixed feelings over Nicleod's plan. The Anglican clergy, having 27 of the 54 existing 
schools had most to lose and were therefore hostile, as they were in Ireland. The Catholics, who owned 13 of the schools, had misgivings but were willing to give the project a trial. The non-conformists were opposed to any State control, but some members of all communions regarded the issue as important for the unity of the country, and for reducing interdenominational rivalry (Wood, 1968, p. 216).

The publishing of the details of Micleod's secular Irish-oriented plan for Trinidad in his last year of office and a few days before Lord Harris's arrival, caused much discussion and anxiety both official and unofficial.

\section{Lord Harris's Philosophy and Plans for Education}

Lord Harris's arrival in 1846 brought some calm to the disturbed state of affairs. He considered the recent resolutions of the Council to have been made without "due regard to the principles of education," for he had once been a teacher and was conversant with the latest pedagogical theories. He treated the question of education on a level of intellectual discussion that was reminiscent of the assumptions of the 18th century philosophes. The work of the teacher was to nurture reason and dispel the darkness of traditional superstition.. He thought that the function of the school was not the mere chore of passing out a minimum of instruction to satisfy the requirements of the Colonial office and the friends of the Negro in Britain. To him education was the most effective instrument that could be 
employed to lift the standards of the laboring classes and provide an avenue of mobility for those who could attain to the higher stages of instruction (Ibid., p. 218).

In regard to the controversy over instruction in the school, he enunciated for the first time in Trinidad the role of the state and drew a distinction between education and instruction (Gt. Britain, P.P., 1847, XXXIX, 325, "Immigration of laborers into the West India Colonies," p. 112). He considered it the role of ministers to improve instruction in the schools by instilling "a moral awareness" and to teach Christian principles. The idea of a common general religious teaching approved by all the churches was a possible solution to the delicate problem of religion.

He was aware that instruction in the schools given by Christian clergy would be prejudicial to Muslim and Hindu children, who in 1846 had no teachers of their own religion. He felt that what was best in the circumstances, though difficult to realize, would be a secular system under the direction of the government with religious instruction given at set times during the week by the minister of the most numerous sect in the area. Such classes were to be attended voluntarily by the pupils (Wood, 1968, p. 220). The previous resolutions had called for a portion of the expenses for school buildings and salaries being raised locally. There was yet no system of local administration through which local contributions could be collected. Judicial functions were carried out by Stipendiary Magis- 
trates, the roads were the responsibility of commissioners, and the police force was administered from Port-of-Spain. No rates or taxes were collected, except from the roads, and the revenue of the colony was dram from import and export taxes.

Harris realized that education would have to be accompanied by the reorganization of local affairs if "the feelings, the habits and forms of a society" were to be instilled in the population. He therefore proposed that the expenses of local government (which included education) would be met by levying rates on the owners of property and land. He hoped that eventually the local rate payers would share in the administration of their neighborhood. Thus he was introducing the people of Trinidad to their responsibility as rate payers, and then to their privileges as part of their preparation for citizenship (Ibid. p. 22I).

Though the Wardens and Territorial ordinances were passed in 1849, for some unexplained reason it was not until 1851 that any detailed proposals for education came up in the Iegislative Council. Iord Harris had announced in 1847 in his original proposals to the Council that every child in Trinidad would be given the opportunity to advance as far as his capacities allowed. His aim was an education open to talent. In each ward there were to be one or more primary schools; and in each district a school where pupils who displayed superior intelligence could be sent. In the future he had hoped that his plan... 
would be rendered complete by the establishment of a college, to which those scholars who might be found fit might be passed on, so that in fact every encouragement would be given to all, however humble their birth to place themselves in such a position as their talents and their industry would show them capable of supporting (Williams, 1962, pp. 203-204).

The resolutions of 1851 were a significant modification of Harris's original plans. The principle of advancement based on talent was left in abeyance. Miention was made only of ward schools and normal schools, and the Hodel Schools in Port-of-Spain.

The resolutions of the Council in 1851 were (Williams, 1962):

1. A Board of Education was to be formed, consisting of the Governor, with such members of the Legislative Council and other persons, being laymen, as may be appointed from time to time by the Governor.

2. An Inspector of Schools was to be appointed with a salary.

3. A training school, with a master and mistress, was to be established for the educational training of teachers; the expense of maintaining such school, with suitable accommodation for the teachers, was to be defrayed from the public funds of the colony.

4. Public schools were to be established at once in each ward of the colony, and at such places most suitable for the convenience of the population.

5. The training and primary schools were to be under the control of the Board of Education, and subject to the supervision of the Inspector.

6. The expenses of erecting and maintaining the school-houses, with suitable accommodation for teachers, and the salaries, were to be defrayed from the funds of the wards.

7. No person was to be appointed master or mis- 
tress unless such person had produced a certificate of good character to the satisfaction of the Board of Education, and until such person had undergone an examination by the Board, and had received a certificate of efficiency.

8. At the primary schools instruction was to be provided for day scholars, and for evening and adult classes.

9. Admission to the primary schools was to be free.

10. Instruction to be given at the training and primary schools was to be secular, and without direct religious or doctrinal teaching ( $p .200$ )..

The number of ward schools grew slowly as show in Table 7:

\section{TABLE 7}

GROWTH OF WARD SCHOOLS

$\begin{array}{ccc}\text { Year } & \begin{array}{l}\text { No. of } \\ \text { Schools }\end{array} & \frac{\text { Enrollment }}{1851} \\ 21 & 23 & 1246 \\ 1856 & 30 & 1461 \\ 1864 & 1823\end{array}$

Source: Port-0f-Spain Gazette, March, 1856. Report of Acting Inspector of Schools, April 15, 1856, Report of Inspector of Schools, DeVerteuil, History of Trinidad, 1884 p. 195.

After 1846, when Lord Harris requested a report on the denominational schools, the number of secular ward schools never amounted to the number of denominational schools at that time, and in 1870, there were still only 30 ward schools. Evidently the ward schools were not keeping pace with the growing population of the country and the ever in- 
creasing proportion of children.

What are the reasons for the failure of this first attempt to establish a coherent national system of education? Some reasons have been advanced. After Lord Harris's departure to become Governor of Miadras, lethargy settled over the education scene. None of Harris's successors, in their capacity of Chairman of the Board of Education, appeared to be concermed enoligh to visit the schools; his practice of donating and presenting prizes immediately lapsed. The Board, too, became apathetic and functioned in an irregular and perfunctory manner. Instead of meeting fortnightly as planned, many members absented themselves from meetings. Between 1864 and 1868, the Board is reported to have met only thirteen times (Keenan, 1870, p. 47).

An ordinance passed in 1847 for creating local bodies in the rural areas to look after the ward schools, when the taxpayers requested them remained ineffective on the statute books, for the municipal bodies were never formed.

It is reasonable to assume that there was an absence of a corporate will of the society and administration to promote the development of a system of education involving the masses. Such persons as were ambitious about the administrative improvements of the country concentrated on the constitution of the Legislative Council or on the principles of the Crown Colony status, and were not inclined to accept the idea that democracy should "slowly broaden down from 
precedent to precedent (Ibid, p. 226)."

Again the great majority of people possessed of some learning lived in the two principal towns of Port-of-Spain and San Fernando, so that the countryside was almost an intellectual wilderness. In many of the wards the people who might have been able to run a municipality were planters, managers, and clerks, few of whom, considering the ethics of the times and of the plantation, would have been interested in local affairs involving popular education (Ibid, p. 228).

The burden of official duties on the local scene fell, therefore, on the wardens themselves. At first these were part-time officers, unpaid and drawn from the indigenous population. Unlike the squires of England they were not men of leisure, for there was no leisured class in the colony. The multifarious and often unrewarding duties of the wardens caused them to be often criticized.

The office of warden had been a means of giving executive experience to local men. But just after Lord Harris left the colony, this measure was abandoned and the 41 wardens or "part-time gentlemen" were replaced by ten full-time district officers of the government. These came to regard themselves, not as leaders of a municipal council of voluntary servants, but rather as agents of the central government in the city, with the result that there was greater efficiency in routine that results from centralization, but associated with it, a deadening of local ini- 
tiative (Ibid., p. 227).

In view of the apathy of the Board of Education,

the wardens tended to neglect the schools, which they seldom indeed visited. One warden is reported to have told some rate-paying farmers, who requested a school in their area, that the consequence of educating the laboring population would be a labor shortage on their estates (Trinidad Sentinel, August 2, 1860). The warden was most probably expressing the opinion of many other minds (Ibid, p. 227).

The attitude of many of the consumers of education themselves was not beyond question. The pressing demands for learning in post-colonial Trinidad were not to be expected among ex-slaves in the 1850s and 160 s. Many parents were illiterate and were inclined to be nonchalant about learning experiences they themselves had not had. Others who had got a smattering were more concerned about "this great education (Gordon, 1963, p. 29)." Children came to school at all ages and left on the caprice of their parents when they had just begun to read and write. The average daily attendance ranged from 50 percent to about 75 percent. Even in the borough schools in Port-of-Spain the average time a boy spent in school was only fourteen months.

Environmental factors also played their part. The many fevers, and other illnesses, the conflicting demands of farm or estate and the schoolroom, the scattered distribution of the population, the overgrown and neglected roads, impassable tracks in the wet season, as well as truancy and 
parental indifference, all compounded the problems of the school.

Added to these was the language problem. While the teaching was in English, the children spoke mainly Spanish or French Creole (patois), which were unintelligible to most of the teachers. The school buildings supplied by the wardens were dilapidated (Keenan, 1870, pp. 9, 19), and were often allotted only because they could not be used for other purposes. The teachers, who were badly paid, of ten lacked the incentive of promotion or sazary increments to urge them to improve their efficiency or to raise the standards of their pupils. The secular and governmental system, too, lacked the spirit of emulation that existed under the denominational system.

Dispiriting as this picture may seem, there were yet, here and there, talented and dedicated teachers even among the Negroes who did excellent work. Outstanding among these was Mr. J. J. Thomas, a self taught Negro who, by 1869, became secretary of the Board of Education, was befriended by Charles Kingsley, was later appointed a Stipendary Justice of the Peace, and in his work, "Froudacity: West Indian Fables by James Anthony Froude," refuted with dignity the English historian J. A. Froude's negrophobe book, "The English in the West Indies (Wood, 1968, p. 229).

Lord Harris had tried to establish a government system of education of divided control in order to instill a sense of community and national awareness in the 
heterogeneous population. The influx of non-Christian East Indians added to the difficulties. The claim of the Indians today that the education of their children was neglected is true only in part, since they originally kept shy of the ward schools as has been stated above. They were most likely inhibited by their linguistic, religious, cultural and social differences. of 1,221 pupils counted in 18 ward schools in 1868, there were only three Hindu children (Wood, 1968, p. 230). The rule which forbade doctrinal teaching in ward schools was not strictly adhered to, and Indians, it is reported, (Grant, 1923, p. 82) believed that by their attending Christian schools their life in the hereafter would be endangered. Most of the East Indians were isolated on the plantations, and a few estate schools were provided. But as the children were also employed in the fields, efforts to develop an educational system including all children ran counter to the demands of the plantation. Even the later Keenan Commission's recommendation for providing estate schools met with little support. A multiplicity of factors, therefore, caused this first ambitious attempt of Lord Harris to founder.

\section{Development of Provisions for Secondary Education}

Lord Harris's proposed unitary system of education was intended to include, in addition to the primary ward schools, higher level divisional schools and ultimately a college with curricula including training in the sciences, 
agriculture and the study of the classics.

Nothing more was heard of post primary education until Governor Keathe in 1857 put forth his proposal for a non-sectarian college similar to the classical Queen's colleges established in Ireland and Nauritius (Gordon, 1963a, p. 75; Wood, 1968, p. 232).

The leading role which the churches had played in providing schools gave to them an influence that developed into a Church-State confrontation in regard to secondary education. Already the ward school system had ceased to expand.

As early as 1836 the Catholics had been operating a finishing school at St. Joseph's convent for "young ladies." This was followed in 1837 by the opening of St. George's College, a secondary school for boys (Gordon, 1963a). A classical school which had been set up by the Church of England during the 1850 s had quickly come to an end for want of financial support and community interest (Keathe to Secretary of State, 1857).

Though formerly tolerant of the ward schools, the Catholics now became uncompromising in the face of this new threat of secularism, for they considered that morals and religion could not be divorced from a classical education (Wood, 1968, p. 233).

The proposed classical school was highly recommended by the Attorney General in his speech to the Legislative Council, and supported by Governor Keathe. The reply of the 
Roman Catholics was a petition to the Queen to disallow the resolution of the Council for founding such a school. The Collegiate School, nevertheless, was established, admitted its first pupils in 1859, and soon proved to be academically a remarkable success. However, called the Godless College, it was publicly regarded as a triumph of Protestantism over Catholicism, since it was mainly attended by protestant boys. In an effort to counter this disadvantage the Roman, Catholics in 1863 established their own college, the College of the Immaculate Conception or St. Mary's College, under the direction of the Fathers of the Congregation of the Holy Ghost, which soon became a rival of the Collegiate School. By 1870 its enrollment was nearly twice that of the secular school (Wood, 1968, p. 234).

A consideration of the purpose of secondary school provisions at this time will give a better understanding of the functions of these schools.

In Lord Harris's scheme of popular education, learning opportunities were to be accessible to the child of humblest birth and were to be limited only by his abilities. The principles on which secondary schools were being set up in the 1850s and 1860s, it will be seen, were of a different order. The Board of Council in 1857 had proposed to estabIish the Collegiate School "to place within the reach of the youth of the colony the opportunity of obtaining a classical education at moderate charge (Williams, 1962, p. 204)." This charge which was fixed at $\$ 15$ per annum proved to be 
high even for the well-to-do people of the colony (Gordon, 1963b). The poorer classes were thereby clearly excluded. The pragmatic implementation of these demands was seen in the enrollment of the school in 1869. The Keenan Cormission (Williams, 1962) revealed that:

The first thing likely to strike a person - . is the strangeness of the fact that whilst the white population, which is only between 5,000 and 6,000 , furnishes 142 pupils to the collegiate estabiishments, the coloured population, which, exclusive of the Coolies, numbers from 60,000 to 70,000, furnishes only 37 pupils. Twenty-four of the coloured pupils are in the Catholic college, and 13 in the Queen's Collegiate School (p. 205).

\section{Legitimacy Requirement}

Further, legitimacy of birth was necessary for admission; but, when it is considered that in 1857, when the Collegiate School was opened, 57 percent of the births registered in Port-of-Spain were illegitimate, and of a population of about 45,000 there were only 374 marriages solemnized (Wood, 1968, p. 233), the requirement of legitimacy was obviously a discrimatory expedient which immediately disqualified all children of former slaves and many of the free-born persons. Secondary education was apparently intended exclusively for the well-born, privileged classes of the society.

The social selection of the pupils is also seen from the fact that the 184 boys receiving secondary education represented only the homes of civil servants, clergymen, planters and proprietors, merchants and professional 
men. There were few colored students, and the Negro and Indian were conspicuously absent (Gordon, 1968, p. 27).

Keenan's statistics show that, out of a total CathoIic population of 50,000 in Trinidad, there were only nine Catholic students who attended voluntarily. This was apparently not an expression of public confidence in the school. Keenan's statistics, however, seem to be inflated since, of the 50,000 Catholics, only the upper classes were financially able or socially eligible to attend. In addition, the inIuence of ecclesiastical pressure upon the faithful of the church cannot be ruled out (Gordon, 1968, p. 92.)

\section{Purpose of Secondary SchooI Provision in the 19th Century}

Before emancipation, wealthy planters were in the habit of sending their children to continue their studies in Europe. With the problems in the sugar industry resulting from emancipation and the introduction of free trade, many planters could not easily do this.

Young men who had gone to Europe to study often did not return. It had seemed to Lord Harris that this brain drain could be prevented if a college offering both classical and scientific courses could be established in the colony (Wood, 1968, p. 232). Secondary schools were started by the Catholics to meet this difficulty (Brathwaite, S. E.S. 7 [1958], p. 14). Rubin and Zavalloni (1969) express the view that: 
Political and cultural as well as economic and religious considerations undoubtedly motivated the establishment of Catholic schools. The French feared breaking cultural ties with France and the spread of Anglicization as much as they feared political and economic discrimination. Denominational control of the schools assured French-Creole control of education, but the schools were the arena for conflicting national as well as denomination interests $(\mathrm{pp}, 36,37)$.

Protestant missionary societies wanted high schools for the education of youth who might become school masters, ministers and lawyers.

Among the French-Creole families the movement for constitutional reform for representation in the Legislative Council regarded St. George's College as a training ground for Trinidad leaders and critics of the colonial government's policy (Gordon, 1963a, p. 225). For West Indians generally at this time secondary education was a means of emulating and competing with English colonial administrators and professional people (Ibid., p. 224).

This attitude was exposed in Governor Keathe's dispatch to the Secretary of State in regard to the opposition the Collegiate School was receiving from the Catholic leaders. It showed that the French element in the society was ostensibly advancing religious objections in their attempt to prevent Trinidad developing as a British colony (Ibid., p. 235).

The Catholic petition to the Queen against the Collegiate School stressed that the principle on which the school was being established were "opposed to the convic- 
tions of all Roman Catholics, who cannot admit to be beneficial any system of education not founded on religion (Ibid., p. 234)." Their second major argument appears to have had validity even in the light of modern curriculum planning. It expressed the conviction that a purely classical education was "not adapted to the circumstances of this island where agriculture and commerce are the principal pursuits of the inhabitants (Ibid., p. 234)."

The Catholic purpose in their secondary school program was also revealed by the Catholic Vicar General who, in 1865, indicated in his correspondence that, with the cooperation of the Holy Ghost Fathers, they had been successful in reestablishing the Catholic college on "a solid basis" in order to meet the difficulty of the government's "neutral" college from which religion had been excluded (Ibid., p. 239).

The social orientation of the Collegiate School was indicated in official circles. The Governor in 1862 viewed the college as geared to supplying the deficiency of competent civil servants who were likely to be "an ornament to the Public Service." The Chief Justice the following year stated that patient industry at their studies at the school could secure to the students "a certain and easy livelihood and the position of a gentleman in afterlife." and open "the highest post to honourable ambition (Gordon, 1963a p. 238)."

Broader aims were conceived by some public interests. 
The school was viewed by the press as likely to "work largely with other influences toward the healing of many social ills and the removal of many social diseases" in a society that needed "the full exercise of every instrument towards the regeneration and union of our discordant and jarring body politic... (Gordon, 1963a, p. 237)."

\section{The Keenan Commission and the Establishment of the Dual System}

The establishment of the secular Collegiate School had caused the Roman Catholic clergy to declare open hostility to any secular education. The Roman Catholic archbishop had pronounced upon the paucity of religious knowledge in the ward schools. Governor Gordon therefore appointed two commissioners, one Catholic and one Protestant to examine and report on the situation. The report submitted showed that the system of religious instruction in the ward schools had falled. Each ward school visited showed that there was the grossest ignorance of the most elementary principles of Christianity.

The Commissioners" "report also suggested that the general standards of the ward schools were as low as that of the religious instruction.

The Governor realized that this called for careful study by an expert in educational affairs from the United Kingdom. The colonial office therefore appointed Patrick Keenan, an Inspector of the National Schools of Ireland to make a comprehensive survey of education in Trinidad. 
The findings of Mr. Keenan were alarming. He found ward school buildings dilapidated and insanitary, more than half of which "would bring discredit on any country that recognized civilization as a principle of government (Wood, 1968, p. 284);" and teachers, some of whom were ignorant, apathetic and demoralized, and of a different religion from that of the majority of the children in the schools. The differences of language were disregarded in teaching; the knowledge of geography and arithmetic was "abysmal." The Normal school was not providing the trained teachers that Lord Harris had envisioned. The root of the malaise, he found, lay in the neglect of those responsible for management. The School Board existed, as we have already shown, more on paper than in fact and local management was nonexistent. The Anglican clergy had been setting up schools in competition with the ward schools. Wood (1968) regards the survey as "the most damning criticism of an institution in Trinidad yet to have appeared (Ibid.. pp. 284, 285)."

Keenan made the following recommendations with regard to primary schools (Triennial Survey, 1955-57):

(a) The compilation of a set of school books suitable to the colony and descriptive of its natural phenomena. productions, \&c.

(b) That the appointment of schoolmistresses should be encouraged with a special view to the teaching of needlework and that attached to each school there should be a workshop and garden in order that the boys might be taught carpentry and agriculture.

(c) The institution of two Reformatory Schools 
based in principle upon a modification of the English Reformatory and Industrial School Acts.

(d) The abolition of the Boys' and Girls' Nodel Schools and also of the Normal School.

(e) That instead of establishing any Government Normal School, a scheme of monitorships should be instituted as an effective means of providing highly qualified teachers for the colony.

(f) That the plan then in force of exclusive management on the part of the State should be abolished and that, in future, all schools should be placed under the care of responsible persons having local relation to or connection with the places in which the schools were situated.

(g) That the management of each ward school should be vested in the clergyman of the same religion as the majority of the pupils--such arrangement, however, not to operate to the prejudice of any person, clergyman or layman, who commanding a sufficient attendance of pupils and a suitable school house might choose to establish a school under his own management.

(h) As regards religious instruction, that no child on account of class, creed or colour, should be refused admittance to a school aided by the State; and that no child should be exposed directly or indirectly to the danger of proselytism.

(i) That every manager should be allowed free scope as to the course of religious instruction he might choose to adopt, and as to the employment of the person by whom such instruction should be imparted.

(j) That the parent, by a formal act of registration, should determine the religion of his child: and that the parish clergyman of the same religion as the child should then have the right to give his coreligionists instruction, at some convenient time. in the schoolroom.

(k) That the principle of paying for ascertained results should be applied to the Trinidad teachers; that one-third of their income should be dependent upon the results of their teaching, as ascertained by the Inspector at an annual examination; that another third should be dependent upon a quarterly report of the manager; and that the remaining third should derive from a "classification" or 
"certificate" salary.

(1) The propriety of extending to the East Indian immigrants the opportunity of participating in the advantages of the public system of education.

(m) The abolition of the existing Board of Education and the appointment of a new Board of twelve members--six Roman Catholics and six Frotestants (pp. 6, 7).

Keenan's careful study of the two colleges revealed fundamental differences in their organization and purposes. The Collegiate School was housed in rented premises that were most unsuitable and uncomfortable for any school. The fee of 315 per term was exclusive and high even for well-todo people. The curriculum of the school was dominated by the requirement of the Cambridge local examinations. There was a preliminary course including reading, dictation, EngIish Grammar, arithmetic, history, geography, and English Composition, and a higher course comprising religious knowledge, English, Latin, Greek, French, German, mathematics, zoology, botany, geology, drawing and music. Art and music were somewhat neglected and there was no provision for science.

Connected with the Cambridge examinations was a scheme of competitive exhibitions or scholarships tenable for three years at a university in Great Britain or Ireland. He had misgivings about concentrating so much of the energy and so many of the aspirations of the community on an enterprise of so limited a scope as the Cambridge examinations. He found the masters gifted and thorough and the boys to be 
hard at work.

At the College of Immaculate Conception, there were two buildings in use, one of which was new and neatly designed and the other in a neglected and dilapidated condition. The fees and pensions for half boarders were moderate, pensions for externs were high and excluded all but the wellto-do.

There were preparatory courses comprising reading, writing, arithmetic, English and French Grammar, history and geography. There were commercial courses and classical courses, Latin and Greek, including the ancient authors and some of the principal fathers of the church. English and French were obligatory and German and Spanish optional. Drawing, vocal and instrumental music were also a part of the curriculum. The classics were also translated into French. So strong indeed was the French influence in the college that it came to be called the "French College" just as the Catholic church was called the "French Church" (Keenan, 1869, in Gordon, 1963b, p. 19).

Keenan was sympathetic to the French influence in the Catholic college, but thought that in an English colony a great public school should be conducted on recognized English principles and advised that the college, though it should not be less French, should be made more English.

Keenan's painstaking description of the two colleges, his comparisons and contrasts revealed that the majority of students, 142, were white and a few, 42, were colored. 
Both the social selection of the pupils and the popularity of the school were revealed by the analysis of the enrollments. Table 8 shows the corresponding figures.

TABIE 8

SOCIAL BACKGROUND OF STUDENTS ENROLLED

IN CLASSICAI SCHOOIS

\begin{tabular}{lccc}
\hline $\begin{array}{c}\text { Occupation of } \\
\text { Parents }\end{array}$ & $\begin{array}{c}\text { Queens } \\
\text { Collegiate }\end{array}$ & St. Mary's & Total \\
\hline Civil Service & 28 & 6 & 34 \\
Clergymen & 3 & - & 3 \\
Planters \& Proprietors & 13 & 41 & 55 \\
Mierchants & 14 & 41 & 55 \\
Professional men & 10 & 29 & 39 \\
\hline & 68 & 117 & 185 \\
\hline
\end{tabular}

Source: Gordon, 1968, p. 27.

According to Keenan's Analysis which we have already questioned the "People flock to the non-endowed college." He therefore concluded that the Catholic College should be brought within the scope of the public system. He also suggested a scheme for the establishment of a West Indian university to avoid the need of "colonists" having to send their children 4,000 miles to obtain it (Gordon, 1963a,p. 279). The Imperial government did not think the time and circumstances warranted the setting up of a university, in view of the unsatisfactory state of primary and secondary education (Wood, 1968, p. 268). 
Keenan had recommended the placing of all schools under the direction of the denominations. This measure, along with government assistance for approved schools, was also advocated by the Roman Catholic archbishop, who also had gone as far as to suggest that the Collegiate School should be abolished and the money thus released should be used for promoting primary denominational education (Ibid., p. 236). Such a move would undoubtedly have taken the control of secondary education completely out of the hands of government.

\section{Education Ordinance of 1870}

The Education Ordinance of 1870 effected a compromise by recognizing two types of schools, namely: the State or govermment schools supported wholly by public funds, and Assisted Denominational Schools receiving financial aid from government. Thus was established the dual control of education which appeared to be a more democratic approach to the control of education. The Education Ordinance also provided for the establishment of a Board of Education, consisting of the Governor as President, and such persons as the Governor might appoint, one of whom was to be named by the Governor as Vice-President; the President, Vice-President and eight members, four chosen by the Roman Catholic members and four by non-Roman Catholic members, were to form an Executive Committee of the Board.

In regard to Secondary Education, the Ordinance provided for the establishment of a college 
in Port-of-Spain, to be called the "Royal College of Trinidad," in place of the Queen's Collegiate School, the management of which was vested in the Governor and a Council to be appointed by the Governor; it also gave the College Council power to affiliate schools of secondary instruction to the Royal College, such schools upon affiliation becoming entitled to grants in aid from public funds.

The same ordinance provided for four exhibitions to the Royal College of pupils from the primary schools, and four scholarships annually of the value of 450 each, for three years, to the students of the Royal College or any affiliated school, tenable at a University in Great

Britain or Ireland (Triennial Survey, 1955-57, p. 8).

\section{Development of Secondary Education After 1870}

When the Education Ordinance was passed in 1870, secondary education was still the province of a small elite who were being trained for the universities and the civil service. At the bottom of the social scale were the Negroes and East Indians, some of whom were receiving the elements of primary schooling. The education of most of the children of the intermediate classes of colored clerks, shopkeepers etc., had been left to the borough schools or a few poorly run private academies (Wood, 1968, p. 235).

In addition to the two collegiate schools for boys which were in operation under the Ordinance of 1870, Naparima College, a Presbyterian college opened since 1884, especially in the interest of the East Indian population, was affiliated in 1900. St. Joseph's Convent School for girls was, by an amendment to the ordinance, affiliated in 1911 (Triennial Survey,.1955-57, p. 10). 
Bishop Anstey of the Anglican Church, an enthusiastic educationalist, established a high school for girls in Port-of-Spain in 1921. This was affiliated and granted aid in 1924. The Bishop also started a high school in Tobago in response to the request of the people there.

The Tobago school was affiliated and granted aid in 1927. The higher education of East Indian girls was provided for by the affiliation of Naparima Girls' High School in 1925. Two other Catholic High Schools, St. Benedict's College and St. Joseph's High School at San Fernando were aided in 1936. These were all fee-paying schools.

\section{Provision for Secondary Education}

In 1870, a "very small and exclusive percentage of the population" was receiving secondary education (Gordon, 1963, p. 242). Access to secondary schooling was virtually closed to Negroes and East Indians. Some few, however, were able to escape the anonymity of lower class life across the narrow isthmus of the College Exhibitions. Four exhibitions to the Royal College were offered to pupils of primary schools, and four scholarships annually of the value of 5450 each, for three years were given to students of the Royal College or any affiliated school, tenable at a university in Great Britain or Ireland (Triennial Survey, 19551957, p. 8). These scholarships and exhibitions were destined to leave a deep impress upon the educational values and social aspirations of the people of the colony. 
The period of increasing interest in secondary schooling following the 1870 ordinance was one of reverses and frustrations. The population which continued to increase by natural growth and by immigration needed increased public services and greater employment opportunities. But the loss of the U.S. sugar market, and competition of beet sugar and foreign production resulted in economic reverses (Gordon,. 1963a, p. 107).

People were looking to education to improve conditions. But education commissions at this time were concerned about greater economy in spending.

The poor standard of teaching and the low achievement caused by inadequate teacher training, as well as the irrelevance of the curricula at both elementary and secondary levels were repeatedly criticized..... Meanwhile, as has been shown, large sums of public funds were being spent to help defray the costs of indenture (Ibid., p. 108). The State, it seems, was not prepared to make any large outlays for educational reform and the administration tended to maintain a level of schooling that was in keeping with the require = ments of the plantation economy. The recommendations of the 1889 Committee, appointed by Governor Sir William Robinson to consider and report on the education system, seem to support this thesis in part.

The Committee recommended among other things:

That the State consider it desirable in the interests of the Commonwealth that the people 
should be educated.

That it is the duty of the parent to perform this duty and not that of the state. . .

That the state should compel a parent to perform this duty, if neglected, and should pay for the education of the child on being satisfied that the parent is unable to do so.

That a child should be educated at the expense of the parent and not at the expense of the taxpayer. ...

That the education required by the state does not extend beyond reading. writing and arithmetic commonly called the three Rs.

That the influence to be exercised by the state over schools, in consideration of the Grant will be directed in encouraging Nianagers to afford a simple and sound system of education suitable to the character of the people and their surroundings, advising managers and teachers, requiring the Rules to be observed, and seeing that proper results are obtained for the monies granted.

That it is not practicable to set up any idol of uniformity or national system of education under the circumstances existing in the colony. . (Williams, 1962, pp. 209, 210).

Thus the philosophy of the times and economic and social expediency were causing Lord Harris's plans to flounder.

\section{Agricultural Education}

The Imperial Government gave subsidies for education, which appear rather destined to sustain the plantation than to promote social reform. Undoubtedly, agricultural education for the youth of the West Indies is a "fundamental requirement" but the establishing of agricultural education at post-primary level in Trinidad at the turn of the century 
seems to lack justification. As Williams (1968) pointed out, it was the society that was out of harmony with agricultural education. The questions involved were social and political and not mainly educational. It was of little use to have the youth qualified in agriculture when the society did not provide facilities for them to own land, unless they were to be perpetually mere cogs in the great wheels of the plantations. The headmaster of Queen's Royal College saw the teaching of agriculture in his school as merely an examination subject. None of his former pupils who had taken the course in agriculture were even "remotely connected" with it or putting the knowledge to any practical use (Gordon, 1963a p. 145). Even in British Guiana agricultural training was regarded as a farce since there was nothing for the students to look forward to in that direction after leaving school (Ibid., p. 151).

The Trinidad Education Commission (1916) advised that agricultural science should be taught as a branch of liberal education in Trinidad; and, for the few who needed it as a technical subject, scholarships should be provided to study at the Department of Agriculture.

At the elementary school level, teachers in training were required to receive instruction in Agricultural Science, including practical work. Two agricultural instructors were attached to the Education Department, but for financial reasons were able to pay few visits to the schools. At many of the schools themselves small garden plots were 
cultivated which the commissioners thought were intended to earn the high bonuses for agriculture. They concluded that agricultural education in Trinidad at that time was little more than a sham and recommended considerable re-organization. As Williams (1951) pointed out, "Agriculture as the living reality in the experience and environment of the child should be the basis of elementary education (p. 46)."

\section{College of Agriculture}

A committee was appointed in 1919 to study the higher education needs in the area of agriculture. The needs for an institution to provide leadership and guidance in agricultural research was recognized. In 1921, the West Indian Agricultural College was founded for this purpose and incorporated by Royal Charter as the Imperial College of Tropical Agriculture, a recognized center teaching Caribbean Agriculture at undergraduate level, giving orientation courses to the agronomist holding a degree in agriculture in a temperate climate and giving post-graduate teaching in Tropical Agriculture and Research.

\section{Lack of Purpose in Education}

By its stated policy the government in Trinidad seemed to disclaim responsibility for progressive development of education. The schools were left almost entirely in the hands of the religious denominations (Williams, 1962, p. 209). In the first decade of the present century, of children under 15 years, 50 percent of the boys and 60 per- 
cent of the girls were not at school. The proportions were even more depressed among the East Indian with one boy in ten and one girl in fourteen attending school (Williams, 1969, p. 22).

The avoidance by government of "any idol of uniformity" meant that the differences of race, religion, and nationality would be accentuated. The effect of the denominational dominance of the education scene was to further alienate the large number of non-Christian Muslims and Hindus, since there was no recognition by government of nonChristian sects (Ibid.).

The low standard of teaching already mentioned was lower still in the denominational schools. Free primary education for every child was therefore a long way from being realized.

These circumstances will help us to understand what must have been the extreme exclusiveness of the secondary education. The four secondary schools of that time were all in the cities, all expensive and aristocratic. There were 796 secondary pupils on roll in 1911, including 194 girls. This meant that of the 46,838 children in primary schools, three in 200 were entering secondary school.

\section{The Collegiate Schools}

The four annual government exhibitions which were provided to bridge the gap between primary and secondary schools were highly valued and keenly contested at the an- 
nual examinations. The other bridge from the classical schools to the universities abroad was in the form of the Island Scholarship which could be competed for by students in the Collegiate and affiliated schools. These came to be regarded as the apex of the educational system of the country. Several "house scholarships" were also offered to the top students at the Secondary School Cambridge Local Exams for study at the higher certificate level in the Cambridge exams.

The Collegiate School and its classical program were set up with the express purpose of countering the influence of the Catholic secondary schools and thus establishing the English orientation of education in the colony (Gordon, 1963, p. 75). This classical program was later accepted by the Catholic schools which became affiliated. The curricula of these schools consequently were modelled after those of the latest public schools of Oxford and Cambridge and the instrument for measurement was Cambridge examinations.

The scholastic record of the two leading classical schools was no mean one in the early years of the 20 th century. The scholars on several occasions scored firsts among the schools of the British Empire, and at other times above the 90th percentile. Queen's Royal College and St. Hary's College were, therefore, English Grammar Schools of the highest order academically (Wood, 1968; Williams, 1969, p. 23). 
These schools were indeed a success from the point of view of scholarship; but it is to be questioned whether they were not a failure in the broader context of the social life of the country. The masses were still illiterate or semi-illiterate; large numbers of children were not yet in the primary school and though there was some mobility among the colored class, the secondary school was still exclusive, and things purely Trinidadian were given scant consideration. Several of the 19th century educators and some of the governors were committed to the principle of equality of educational opportunity. Yet, when the Collegiate School was founded, it seemed quite clear that the schooling was intended for the upper classes of whites. As the number of secondary schools increased in the early 20 th century and more opportunity was provided for study abroad and for secondary education from public funds, no student could be prevented from competing for the coveted places. The result was that excellence proved not to be confined within class or color lines as several middle class lads rose to places of respect in the professions and administration. The competitive examination, as Brathwaite (1953) explains, "was the ladder thus established by the educational system that became one of the most important methods by which members of the middle and lower classes could improve their position on the occupational scale and come to play an important role in public affairs (p. 223)." Trinidad and Tobago's own Prime Minister, Dr. Eric Williams, is perhaps the most 
patent example of this mobility (p. 233). Wardle's (1970) remark in reference to the problem of equal opportunity in education in England applies with equal force to the Trinidad and Tobago situation: "Whatever the virtues of the grammar school are, it was not intended for the education of the whole population (p. 138)."

One of the unfortunate results of the examinations system was the unhealthy rivalry that was produced among the youth. Parents and children came to esteem the coveted places not only for the academic achievement value, but as a symbol of status, and many successful students viewed themselves as socially superior to their fellows. The terms "exhibition winner" and "island scholar" took on much meaning beyond their intrinsic worth.

\section{The College Exhibition}

The preparation and "coaching" for the College Exhibition examination exercised a stunting effect upon the development of the primary school as the curriculum was truncated to meet the requirements of the 11- to 12-year age group aspirants. Special "exhibition classes" were conducted, and young children attended special classes early and late in their attempt to acquire the facts of Arithmetic, English, Geography and general knowledge which were required. The ineffective results of this type of program were shown in the report of the Director of Education (Report, 1946) who recorded that, 
Candidates are subjected to undue cramming and strain at a tender age; some teachers tend to neglect the ordinary pupils in favor of those who can pay for extra lessons, and candidates concentrate only on the subject of examination to the detriment of broad educational foundation... Many successful candidates in the past have faded completely away in the secondary school for lack of sound grounding ( $p, 3)$.

\section{Education Commissions 1916-1954}

Education Commission 1914-1916

The Education Commission of Trinidad was appointed in June 1914 to examine the questions of (1) economy in expenditure for elementary and secondary education (2) the efficiency of the organization of the system and (3) the feasibility of extending the scope of the existing Education Ordinances. Since 1895, the population had increased by approximately 85,000 and the number of schools had increased proportionately. But the number of pupils had more than doubled in 20 years. Government was concermed with reducing expenditure on education which had increased from $\$ 30,994$ to 559,464 in the 20-year period (Gordon in Caribbean Quarterly, 1964). The factor of economy was therefore significant in the commission's deliberations. The changes recómmended by the commission modified some of the main features of public education in the 19th century and abolished others.

Recommendations of the Trinidad Commission, 1914-1916

In regard to secondary education the commission regarded the uniform curriculum in secondary schools as 
"efficiently conducted," but advised that:

(1) the emphasis on classical studies was not best suited to the needs of Trinidad.

(2) secondary schools should prepare boys for university and professional careers, but the main object should be to prepare the majority for official, commercial and agricultural pursuits; to that end a modern subject and science alternative should be provided for senior forms.

(3) modern studies, mathematics and Natural Sciences should also be alternative studies to classics in the annual competition for Trinidad scholarships; subsidiary subjects from each should be taken with the main subject to prevent over-specialization.

(4) agricultural Science should be taught as a branch of liberal education in Trinidad.

(5) existing provision at the Practising School for girls for higher education of non-Catholic girls was quite inadequate.

(6) savings effected by reducing of Trinidad Scholarships for universities abroad should be applied to junior and serior exhibitions tenable at Queen's Royal College or an affiliated school.

(7) instead of elementary and secondary education being administered by the Board of Education and the College Council, the Educational System as a whole should be administered by an Education Board.

(8) the chairman of the Education Board, to be known 
as the Director of Education, should be the head instead of the Governor (Caribbean Quarterly, Vol. 10, No. 2, June, 1964, pp. 19-39).

Other general recommendations were (Triennial Survey, 1955-57):

Elementary education

(1) Efficiency grants, varying according to the efficiency grading of the school, to be payable on account of every pupil in average attendance.

(2) Small and unnecessary government schools should be closed in districts where accommodation for their pupils can be found in neighboring assisted schools.

(3) The Education Authority should exercise more rigid supervision over schools that do not satisfy the requirements of the law.

(4) Government schools should be established in new districts containing a number of scholars belonging to different denominations only sufficient for a single school, and aid should not be given to any other schools in such districts.

(5) Attendance should not be reckoned for any scholar of an elementary school under the age of 5 or over 14.

(6) A system of inspection of elementary schools, supplemented by informal examination, should be substituted for the existing system of examination.

(7) Practical school gardening should form part of the work in all country schools and arrangements be made for the supervision of the school gardens by the resident Agricultural Adviser of the Department of Agriculture.

Secondary education

(8) The method of payment of annual grants to schools affiliated to the Queen's Royal College should be revised. 
(9) The principal of every affiliated school should be permitted to adopt a curriculum suited to the needs of his own school.

(10) A science laboratory should be provided at the Queen's Royal College and assistance for the same purpose given to St. Mary's College. The principles of agricultural science should be taught as far as possible to all boys in the lower forms and an agricultural bias given to the science instruction on the modern side in the upper forms.

(II) Senior and junior exhibitions, tenable at a secondary school should be established and two scholarships offered for competition annually, open to both boys and girls.

Governing bodies

(12) The College Council and the Board of Education should be replaced by a single Education Authority.

(13) The head of the Education Department should be entitled Director of Education ( $\mathrm{pp}, 9,10$ ).

In his evidence before the commission the Principal of Queen's Royal College reported that the curriculum of the school was suited to a few clever boys of the school rather than to the majority of the pupils. This led the commission to recommend a revision of the curriculum.

While the plan of exhibitions and scholarships enabled a few of the youth to study abroad and enter the professions, the very system tended to emphasize the aversion to manual occupations-a response to the memories of chattel slavery--which found its way even among many of the less privileged classes. It was the society, however, that had created the school system.

Miany a youth was attracted to the secondary school as a means of attaining the desired white collar jobs. The 
prestigious positions in the civil service were as yet be yond the reach of colored and dark skinned persons and so status was sought in the professions of law and medicine (Brathwaite, 1935).

This avoidance of education for the productive employments of life could certainly not contribute to the maintaining of a viable society. Such a state of affairs was forcefully deprecated by the survey commission of the educational system of the Philippines in language that contains salutary lessons for the West Indies (Williams, 1968):

No country can prosper which thus lives on its own capital. No society should tolerate, much less maintain, an educational institution which even lends support to the development of such attitudes. Any educational system that serves primarily as a way of escape from the fundamental productive occupations for the more able members of society is certainly not worthy of public support. We should characterize such a system, not as democractic, but as narrowly and crassly individualistic ( $p .48)$.

This is the way the Commission of $1914-1916$ was pointing; but its recommendations for reform in the secondary curriculum did not meet with any immediate response.

\section{The Education Commission of 1931}

As secondary school enrollment continued to increase slowly with the opening of more private schools, it was to be observed that the graduates of the schools still were under the influence of 19th century values. They still sought white collar jobs even as late as the 1930s, when there was increasing unemployment among clerical and commercial workers (Gordon, 1963, p. 266, 267). 
At the time of the Commission's investigation, significant changes had already taken place in education in the U.S.A. and there was also a process of change in England. The Latin schools of earlier America were already replaced by the academy and the public high school whose curricula were geared to adjustment of the pupil and fulfillment of his needs. In England the Hadow Report (1926) had already announced the imminence of universal secondary education. and the institution of a "moderm school" for secondary work along non-academic lines (Cramer \& Brown, 1965, pp. 65, 220, 247).

Meanwhile in Trinidad and Tobago the usual educational problems persisted: thousands of children not attending school; insufficiency of trained teachers; irrelevancy of curricula, and the inadequate financing of education.

In these circumstances, the Commission of 1931 was appointed to study the problems of education and make recommendations for improvement of the system in the eastern Caribbean colonies. The Commission found that the expenditure on primary education per child in Trinidad and Tobago was about a quarter of that in England (Marriot-Nayhew, 1933, p. 15). They considered that most of the problems were due to a lack of expert advice or administration, which was mainly a question of money.

\section{A New Type of School.}

Numerous recommendations were made relevant to the 
many inadequacies at the primary level of schools in the West Indies. With regard to secondary education, the Commission recommended the provision of new post-primary "modern schools" for ages 12-15. It was not intended to replace the grammar school. but to be supplementary and different in its objectives. The school was to be a new and additional type of school

- . providing courses of instruction that are practical in the broadest sense, not merely vocational or utilitarian, but with a cultural basis of general education, directed essentially to the stimulation of interest in the pupils' social and industrial environment, and calculated to create a taste and aptitude for industrial, agricultural, and commercial pursuits, or for social service in primary schools and elsewhere, rather than for the "learned" professions and sedentary or clerical posts in Government Service. We propose to call this new type of school the "Modern School" and the present type, which will continue, the "Classical School(Gordon, 1968, p. 181)."

Aware of the objections which would be raised to the proposed school by conservative parents whose minds and aspirations were set on the traditional secondary school, the Commissioners were quite firm in declaring that there was to be no question of inferiority of the modern school in staffing and equipment, in relation to the classical school, and that government should give explicit recognition of parity of value of the certificate awarded on termination of the modern school courses, with the Cambridge School Certificate (Gordon, 1968, p. 182, 183).

The proposed modern school will at once be seen to have been based on philosophical purposes that were more comprehensive than those of the classical school, more likely 
to meet the needs of the majority of the youth of the country.

The Training of Teachers

The inadequacy of trained teachers also came under scrutiny. There was a notable lack of qualified teachers throughout the West Indies, only 10 percent of them being qualified but much greater in Trinidad where, because of the existance of the Government Training College and the denominational training colleges, the proportion was 27 percent. Many primary teachers were provided through the pupil teacher system. Because of financial limitations the Commission did not foresee a sudden increase in the number of trained teachers, but advised that there should be a diminishing need of pupil teachers.

Though Barbados and Trinidad were better favored than other West Indian islands in regard to teachers for secondary schools, the Commissioners felt that the success of secondary education would depend on the possibility of recruiting staff from the West Indian islands by means of local university training; for, even with Island Scholarships granted for study abroad, it was not possible to obtain the large number of secondary teachers that would be needed.

The Marriott-Maynew Commission questioned the validity of the aims of education in the West Indies. The situation of education at that time they found to have been due 
to an effort "to adopt English aims and methods without the material resources of England (Narriott-Mayhew 1933, p. 21)." This remark undoubtedly had reference to the externally oriented program of the classical secondary schools. Yet the Commissioners showed the "main cause of the backwardness," in spite of the depressed economic world conditions of the times, to have been the failure to make adequate financial provision for educational development (Gordon, 1968. p. 53).

Though a great many reforms did not immediately emerge from the recommendations, later developments proved their proposals to have been sound.

Such ordinances as immediately followed were mainly related to primary education. As a result of the rapid growth of the assisted primary schools under the provisions of the Dual System, several of the denominations established schools in the same small community. This led to interdenominational rivalry and waste of public finance. It is to be noted that similar circumstances existed in early educational development in Kenya (Sheffield, 1971, p. 7), and Australia (Cramer \& Brown, 1965, pp. 117, 118). Ordinances were therefore passed in 1933 to control this situation (Triennial Survey, 1955-1957):

(a) That authority to decide which schools are, and which schools are not, necessary should rest with the Governor.

(b) The amendment of the constitution and powers of the Education Board and placing the authority for making Regulations in the hands of the Governor. 
(c) The extension of the powers and responsibilities of the Boards of Mianagement.

(d) The recognition of an Association, approved by the Governor, for the establishment of East Indian schools (p. 11).

The West India Royal Commission 1938

The West India Royal Commission 1938 under the chairmanship of Rt. Hon. Lord Moyne, D.S.0., arrived in Trinidad in February, 1939 and spent several weeks examining all aspects of life in the country. Education was not its main concern, though it took a very close look at the operation of the system. Many observations made in reference to the West Indies as a whole apply with equal relevance to Trinidad and Tobago.

The Commission found "sexious inadequacies in the educational operations," in almost every respect (Moyne, 1945 p. 12). In reference to the aims and objectives of education, they showed that education had not only a moral but a technical aspect. The school needed to impart not only a "knowledge of techniques" but also of the correct use for the mutual benefit of the individual and the community. Neither in England nor in Trinidad, they averred, had education attained that standard. The force of long tradition had given prestige to the literary side of education and had caused insufficient attention to be paid in England to the modification of systems of education to meet change in needs. The coming of universal education, therefore, had caught the school unprepared to meet the demands of the many youth who 
had, for the first time, come under their influence. The relevance of such observations for West Indian system was clear since the schools were modelled on those of 19 th century England. Historical reasons had conditioned the too pronounced "literary bias" in England. The Commissioners therefore wished to see an end in the West Indies of "the illogical and wasteful system" that promoted a literary curriculum for only white collar jobs in a region where most of the employment opportunities were related to agriculture (Moyne, 1945, p. 120).

These views of the Commissioners were admittedly correct as they coincided with the long standing metropolitan concept of the West Indian islands as producers of sugar. The idea of the West Indian islands developing into small industrialized and exporting countries had not yet been perceived.

\section{University Education}

The Commission regretted that the only means of providing higher education was by way of Island Scholarships, and expressed the desirability of a university education which did not separate the student so completely from his own environment (Ibid., 102).

Witnesses before the commission were divided as to the desirability of a university for the region. The secondary schools were not producing a sufficiently large number of potential students to warrant the great expense involved, 
and the prospects of employment for graduates were not hopeful. The Commission thought that a system of faculties in different islands was worthy of consideration rather than a single university in one colony; but, because there were other more urgent demands for financial outlays, they did not feel they were in a position to make recommendations on the matter (Ibid., 102, 103).

Thus, a means of supplying secondary school teachers was destined to wait for many more years.

\section{The Dual System}

With the majority of schools in the area under denominational control, the administration and finance of education was so often divided between the Christian Churches and Government that it became difficult to formulate as well as implement a progressive educational policy. Since few churches could continue to receive much financial support from metropolitan sources, government support had increased to the extent that the role of the churches was mainly confined to providing management, and supplying and maintaining buildings (Ibid., p. 94). There were persons who thought that in these circumstances government should formally assume the whole responsibility and control of education. Teachers criticized the control of the churches in regard to discipline, appointment, and promotions. This was found to be the case in Trinidad (as elsewhere) where denominational control was among the most centralized (Ibid., p. 116). 
The Commission felt that the denomination system still enjoyed much popular support and any attempt to abolish it would lead to much opposition. They regarded the religious influence of the church as one of the few forces in the area that tended toward social cohesiveness, though there was also widespread feeling that sectarian concerns in education, in relation to management employment and lay participation by teachers, led to separatism. The Commission concluded that certain modifications were necessary in denominational control in the interest of educational efficiency (Ibid., p. 94).

\section{The Working Party 1954}

For a number of years Directors of Education in Trinidad and Tobago had been advocating that a committee be appointed to make a survey of the educational position in the colony. In view of the rapidly increasing child population and the rising costs of providing primary and secondary education, it was necessary to make recommendations for future development.

The Working Party, consisting of three members, including Mir. I. R. Missen, M.C., M.A., Chief Education Officer, East Suffolk Education Committee, and Mr. Howard Haden, in.A., the Director of Education of the colony of that time, was appointed by the Governor of Trinidad, Sir Hubert Rance. The Governor had publicly expressed his desire for a better and more effective approach to education in order to make the 
the people more conscious of their increasing political responsibility (Craig, 1956, p. 63, cited in Gooding, 1961, p. 155).

The Working Party made a quick three-month survey of the educational system, and re-emphasized the problems of an unrealistic curriculum and obsolete methods. The College Exhibition was severely criticized as a method of entrance to a secondary school.

\section{Supply of Teachers}

The increasing number of untrained teachers being employed was remarked upon by the committee, who stressed the danger of the continuance of such a system. They suggested, however, that rather than abolish the pupil teacher system, it might be brought under the control of the Teachers' Training College (Missen, 1954, p. 63).

The syllabuses of the secondary schools leading to the Cambridge School Certificate Examination were shown to be producing identical courses of study, thus immobilizing the curriculum. There were many pupils who left school without receiving any certificate, and this resulted in wastage of capitation grants and grants for buildings to assisted schools Ibid., p. 8).

The Working Party 1954 carried out its survey of education in a very important period of the social and political development of Trinidad and Tobago, but its contribution was not regarded as being new or dynamic. The period was one 
ripe for change, when both the government and the people were looking forward to changes consonant with the passing of the colonial system of government. The committee seemed not to have come to grips with the fundamental problems of educational provision.

\section{Progress Toward Independence and the New Era of Educational Planning}

The constitution which came into effect in 1950 was another important milestone in the progress towards responsible govermment. The number of elected members in the Iegislative Council was increased, and the Executive Council shed its status as an advisory body to assume the role of principal instrument of policy with a majority of elected members and a ministerial system. Each of the members of the Executive Council was appointed as Minister in charge of a number of government departments. Education became the charge of the Minister of Education and Social Services (Trinidad and Tobago: The Making of a Nation, 1962, p. 8). Other social changes were following in quick succession.

The Building of National Unity

The new government had among its purposes the bringing about of national solidarity and the democratic conducting of public affairs. There were several critical goals. These included

(1) Morality in public affairs and the elimination of graft and discrimination in public life and appointments. 
(2) The emancipation of the women of the country with a view to their obtaining of equality with men in the political of the country

(3) A healthy inter-racialism and the removal of the tension in the multi-ethnic society

(4) The abolition of the Crown Colony

(5) The introduction of principles and organizations for planning on a national scale

(6) The removal of all the tax evasions which had plagued the country's development in the colonial period.

(7) The introduction of free secondary education (Williams, 1962, pp. 244-246).

\section{Exit Crown Colony}

At the time of the Haurice Committee 1959, revolutionary changes had already occurred in the internal government of the country. One of the first achievements of the new government was to secure the removal of the Crown Colony. The Cabinet System was introduced, the Chief linister became the Fremier, and the Governor was required to act on the advice of the Primier, with regard to the continuance of the Legislative Council (T. \& T.: The Making of a Nation, 1962, p. 9).

\section{Church-State Relations}

The new government entered into a "concordat" with the denominations by which the denominational character of the schools was recognized, and the schools were incorporated into the govemment's policy of free secondary education. In the areas of appointment, transfer, and dismissal of teachers in denominational schools, assurances were given by Gov- 
ernment in regard to questions of faith and morals (Williams, 1962, p. 246).

\section{East Indian Advancement}

The East Indians' existence in Trinidad since 1845 had been mainly confined to the estates. To some extent they had been apathetic to educational advancement. Through the efforts of the Presbyterian hission Schools, several of them had come to realize the importance of education and had been converted to Christianity. The Compulsory Education Ordinance passed by the legislative Council in 1935 had left their children free from labor on the cane fields (Triennial Survey, 1959, p. 12). Representations were made in 1949 by the Hindu and Islamic groups, who ropresented about one-third of the island's population, for equal rights with Christian denominations to open schools. This was granted and assistance was provided for the first time under the terms of the Dual System for a non-Christian body, the Sanatan Dharma iraha Saba, to open a school. As this movement grew, secondary schools were also established thus strengthening the cultural divisions in the society. By 1953, there were 33 non-Christian schools in existence in the country.

\section{Selection for Secondary School: The College Exhibition}

The limited opportunities provided for free secondary education in Trinidad and Tobago gave to this level of schooling $a$ value and a status beyond its intrinsic worth. By the Trinidad Ordinance of 1870, four free places were provided 
through competition by examination for primary pupils to enter the secondary schools. The examination was called the College Exhibition, a difficult examination for boys under 12 years of age. The number of free places made available by the government was increased to 16 in 1942, and the number continued to grow, and rose suddenly to 100 in 1950, the year of the new constitution, finally reaching over 400 by 1958. Table 9 shows the increase in the number of places awarded from 1950 to 1958.

TABLE 9

COLIEGE EXHIBITION PASSES AND AWARDS 1950 - 1958

\begin{tabular}{lllll}
\hline Year & No. Sat & No. Passed & Percentage & Awarded So \\
\hline 1950 & 1,156 & 235 & 20.03 & 101 \\
1951 & 1,013 & 346 & 34.15 & 100 \\
1952 & 1,316 & 342 & 25.98 & 125 \\
1953 & 1,574 & 536 & 39.00 & 175 \\
1954 & 2,095 & 814 & 38.85 & 207 \\
1955 & 2,756 & 913 & 33.12 & 203 \\
1956 & 2,957 & 765 & 25.87 & 265 \\
1957 & 3,214 & 870 & 27.06 & 401 \\
1958 & 3,095 & 586 & 19.01 & 404 \\
\hline
\end{tabular}

Source: Trinidad and Tobago Administration Reports of the Education Department for the years 1950-1958.

As these figures indicate, there had been a steady increase in the number of children receiving free secondary 
education, up to the time of the appearance of the People's National Movement (P.N.M.) with its dynamic leader, Dr. Eric Williams. As in Jamaica, so in Trinidad since that time, there has been a "dramatic increase in secondary education supported by a competitive free-place system, which enables a big cross-section of the public to aspire to a secondary education for the first time in the history of the West Indies (Gordon, 1962, pp. 298, 299).

By 1957 there were 17 assisted and govemment secondary schools, including the San Fernando Technical Institute. The need was expressed of diversifying the curricula in new secondary school so as to give more prominence to technical and commerical subjects.

In the secondary schools there was a remarkable difference between government and assisted schools in regard to government superivision, teacher qualification, methods of appointment of staff, and general conditions of service (Triennial Survey, 1959 ). All these inequalities needed to be removed for the proper functioning of the system. Greater still was the difference between these schools and the many private secondary schools, poor in staff and equipment, which had mushroomed into existence to meet the achievement need of the thousands of lower class East Indians and Negroes who were unable to secure places in the better schools.

In spite of the new government's efforts to "broaden the base" of education by increasing the number of free places, secondary education was still "severely restricted 
to the few."

Principals of Denominational Secondary Schools Disconcerted

The assisted secondary schools had been since the latter part of the 19th century the main providers of secondary education. As late as 1958 there were 18 assisted secondary schools, two government secondary schools and 23 private secondary schools. This new invasion of their portals caused by the increasing number of exhibitions, was disturbing to the heads of some assisted denominational schools, who saw the possibility of their school places being filled in future by free government exhibitioners, some of whom they regarded as being below standard academically. It is worthy of consideration, in this regard, that the exhibition not only admitted a child but also gave a choice of a school of the prestigious type, from which many of the feepaying students of middle-class vintage would be excluded by pressure of government applicants.

These principals intended to carry on their own internal examinations for final admission to their schools.

The Maurice Committee 1959

This recalcitrant attitude exhibited by the principals brought forcibly to view the fact that the educational system was inadequate to meet the quantitative needs of a country on the threshold of independence, and about to enter a twentieth century world being constantly transformed by technological and scientific advance, and even less adequate 
to give the necessary leadership and direction in social change.

Made aware of these weaknesses, the government, in July 1957, appointed the Committee on General Education, consisting of 22 persons and comprising members of government, the clergy, and outstanding educators, under the chairmanship of Mr. J. Hamilton Maurice, with the approval of the Governor in council. The terms of reference of the committee were (Naurice, 1960):

To consider the operation of the educational system of the country and make recommendations on future policy related to the curriculum, the improvement of academic and other standards and the integration of the diverse elements which compose our population ( $p .3$ ).

In order to seek solutions to its educational problems in the past the government had turned mainly to metropolitan commissions. These had come from the mother country in order to give some direction. They investigated, criticized and made their recomendations, few of which effected any remarkable change in the development of education. But the period of the late 1950s called for definite aims and purposes, because of the social, economic, and political movement in the country.

As the Maurice Committee observed, "It was the first time in the history of the country that an inquiry into its education system was put completely into the hands of a local committee (Ibid., p. 23)." The concern for national unity was prominent in the committee's deliberations as it sought 
"to find some way to integrate the diverse elements which comprise our mixed population of many races and many more creeds," in view of the fact that schools were built for children of a particular religion or race (Ibid., p. 25).

In order to grasp and present the important issues of education in Trinidad and Tobago, the committee carried out the most scrutinizing and comprehensive investigation of education ever undertaken in the history of the country. The various aspects of the system were examined and presented with numerous recommendations to the government. Some of these more pertinent to this study are presented here.

\section{The Dual System}

The committee looked into the Dual System and remarked that fifteen separate administrative denominational boards tended to create and perpetuate an unfortunate division of plural and parallel societies in a country that was seeking unification in nationhood. The problems implicit. in the system were: the mode of allocation and distribution of elementary schools; the authority of government in the system and the need for a single administrative authority; the freedom of the parent with regard to religious education, and the continuing moral role of the churches.

Fifteen separate authorities of Boards of lianagement were responsible for choosing sites, building schools, and controlling teachers. All these belonged to and were subject to one education department. This occasioned problems with 
regard to inequalities in promotions and seniority, one of the worst aspects of the Dual System.

Many schools, too, though denominational in name, did not truly bear that quality when pupil content was considered; for example, 87 percent of Presbyterian enrollment were not of that faith; 40 percent of Church of England; 80 percent of Moravian, and 70 percent of African liethodist Episcopal. Table 10 shows the distribution of pupils by denomination in primary schools in 1958.

\section{Proposed Administrative Structure}

The Maurice Committee made important proposals for the machinery of administration reminiscent of Lord Harris's embryonic Ward School system in 1847, and resembling the English Iocal Education Authorities of 1902. The country was to be divided into eight local education areas, with an executive department corresponding to each, and administered by a local education officer and his assistants. Centrally in government would be the Minister of Education and his Advisory Council, the Central Council of Education, the Permanent Secretary, the Chief Education Officer, the Chief Financial officer and assistants to the Chief Education Officer. The Office of Director of Education would then cease to exist, thus eliminating the uncertainty, confusion and delay which was caused by overlapping of responsibilities (Maurice, 1960 , pp.33-44). The administrative structure proposed by the Committee is illustrated in Figure 2. 
TABLE 10

DISTRIBUTION OF PUPIIS BY REIIGION AMONG THE VARIOUS

DENOMINATIONAL AND GOVERNIENT PRIMARY SCHOOLS - 1958

\begin{tabular}{|c|c|c|c|c|c|c|c|c|c|c|c|c|}
\hline Trope of Schools & $\begin{array}{l}\text { No, of } \\
\text { Schools }\end{array}$ & E.C. & R.C. & Presby. & bie thod. & Moravn. & Hindu & Miuslim & S.D.A. & Bapt. & Others & Total \\
\hline Government & 68 & 8,365 & 20,411 & 698 & 460 & 1,223 & 6.533 & 1,881 & 461 & 521 & 805 & 31,388 \\
\hline Roman Catholic & 125 & 5.345 & 38,828 & 565 & 156 & 144 & 4.770 & 1.135 & 196 & 212 & 413 & 51,774 \\
\hline Presbyterian & 72 & 1,287 & 3.332 & 3.912 & 63 & 17 & 17.233 & 3.480 & 123 & 259 & 171 & 29,877 \\
\hline Anglican & 66 & 16,931 & 4.726 & 550 & 407 & 114 & 3.406 & 896 & 390 & 358 & 549 & 28,327 \\
\hline Methodist & 12 & 1.095 & 587 & 26 & 1.444 & 100 & 103 & 57 & 204 & 18 & 50 & 3.584 \\
\hline Moravian & 2 & 227 & 173 & 8 & 17 & 82 & 2 & - & 7 & - & 8 & 524 \\
\hline Baptist & 3 & 38 & 50 & $-\infty$ & -- & $-\infty$ & 138 & 53 & 10 & 450 & -- & 748 \\
\hline $\begin{array}{l}\text { African Methodist } \\
\text { Episcopal }\end{array}$ & 1 & 95 & 64 & 5 & 18 & 2 & $-\infty$ & 2 & 4 & 4 & 41 & 235 \\
\hline $\begin{array}{l}\text { Seventh-day } \\
\text { Adventist }\end{array}$ & 5 & 303 & 257 & 39 & 25 & 2 & 23 & 14 & 573 & 20 & 49 & 1.305 \\
\hline $\begin{array}{l}\text { IIndu: } \\
\text { Sanatan Dharma } \\
\text { Maha Sabha }\end{array}$ & 34 & 222 & 506 & 189 & 7 & $-\infty$ & 9.336 & 621 & 9 & 6 & 15 & 10,911 \\
\hline $\begin{array}{l}\text { Arya Pratinldhi } \\
\text { Sabha }\end{array}$ & 8 & 122 & 226 & 114 & 2 & $-\infty$ & 2,332 & 415 & 9 & 2 & 60 & 3,282 \\
\hline Kabir Panth Assoc. & 1 & 6 & $?$ & 1 & $\rightarrow \infty$ & - & 86 & 21 & $-\infty$ & 1 & $-\infty$ & 122 \\
\hline Muslims & & & & & & & & & & & & \\
\hline $\begin{array}{c}\text { Tackveeyatal Isla- } \\
\text { mia Association }\end{array}$ & 5 & 73 & 156 & 19 & - & $-\infty$ & 371 & 1,251 & 1 & $\cdots 1$ & 19 & 1,891 \\
\hline $\begin{array}{l}\text { Anjuman Sunnat UI } \\
\text { Jamaat Association }\end{array}$ & 6 & 33 & 40 & 40 & 2 & $-\infty$ & 440 & 1,150 & 7 & $-\infty$ & 5 & 1.717 \\
\hline $\begin{array}{l}\text { Trinfiad Muslim } \\
\text { Ieague }\end{array}$ & 3 & 37 & 49 & 25 & -- & - & 68 & 467 & 1 & 9 & $\infty$ & 656 \\
\hline $\begin{array}{l}\text { Orphanages and } \\
\text { Industrial Schools }\end{array}$ & 5 & 385 & 532 & 7 & 4 & 4 & 10 & 3 & 3 & 1 & 4 & 953 \\
\hline & $4 \overline{15}$ & 34,564 & 52.983 & 6,198 & 2,615 & 1,688 & 44.851 & 11.446 & 2,898 & 862 & 2,189 & 167,294 \\
\hline
\end{tabular}

Sources: Trinidad and Tobago: Administration Report of the Department of Education, 1958, p. I7
N.B. Discrepancles in the column totals are not explained in the document. 
ORGANIZATION OF ADMINISTRATION PROPOSED BY MAURICE COMMITTEE 1959

Minister of Education

Central Advisory Council of Education Presided over by Minister

Permanent Secretary

Chief Education Officer Chief Financial officer Asst. to Chief Ed. Officer

Executive Departments of Eight Local Areas

Local Education Committees Each with Education Officen

Local Education Officer and Assistants for Each Area

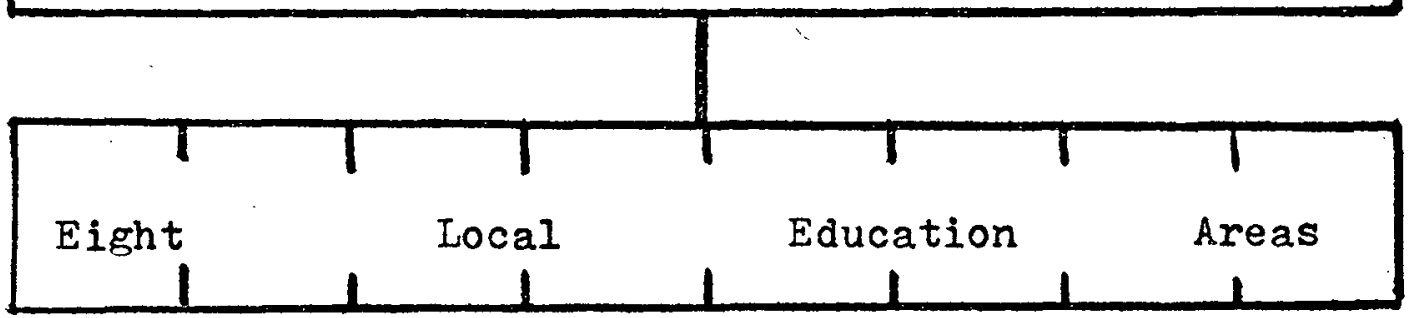

Figure 2. 
The Committee was not in favor of the continuance of the all-age (5-15) elementary school, with its over-age pupils, physically too big, and socially too mature for their environment, hence with little incentive for work and study Ibid., p. 43).

\section{College Exhibition Examination}

The selective College Exhibition examination was also criticized. The scope of work and questions were regarded as too difficult for the young children who were constantly pressured, while the curriculum of the primary school was being stunted.

The uncooperative attitude of the principals of denominational secondary schools in conducting a supplementary entrance examination for their own schools was criticized, and recommendations made to countermand this procedure.

The Committee also viewed as an irregularity the growing number of preparatory or pre-secondary classes attached to these schools.

\section{The Secondary Schools}

The stock criticisms were also made about the secondary schools of the country. With the exception of the recently constructed Technical School at San Fernando, the secondary schools were all grammar schools with much irrelevance in the curricula (Maurice, 1960, p. 47).

The secondary schools had for many years been 
preparing students for the Cambridge School Certificate and Higher Certificate examinations. A certain amount of classical education was valuable, but the committee thought that the type of school best suited to the country's need was the comprehensive school. The curricula of all secondary schools, they showed, should be planned on the basis of aims and purposes, and all types of secondary school should be given equal recognition. A great waste of government grants was in evidence. To encourage higher levels of achievement, an age limit for writing examinations was suggested, and failures were thought to be also due to causes other than lack of student ability (Ibid., p. 48). A wide range of recommendations was made involving supervision, the teacher, new types of school and realistic curricula geared to integrating both academic and practical education.

\section{The Teacher}

The use of pupil teachers was found to be in existence also in the secondary school, owing to the fact that there was a marked inadequacy of graduate staff in the schools, especially in non-government schools and in the areas of Mathematics and Science (Ibid., p. 2l). Table 11 shows the analysis of teacher qualifications in secondary schools in 1958. The large number of untrained teachers holding only the school certificate was in evidence, as well as the greater percentage of trained and graduate staff in the government schools. 
TABIE 11

TEACHERS IN SCHOOLS AND COLIEEES CLASSIFIED

BY QUALIFICATION, DECEMBER, 1958

Secondary Schools

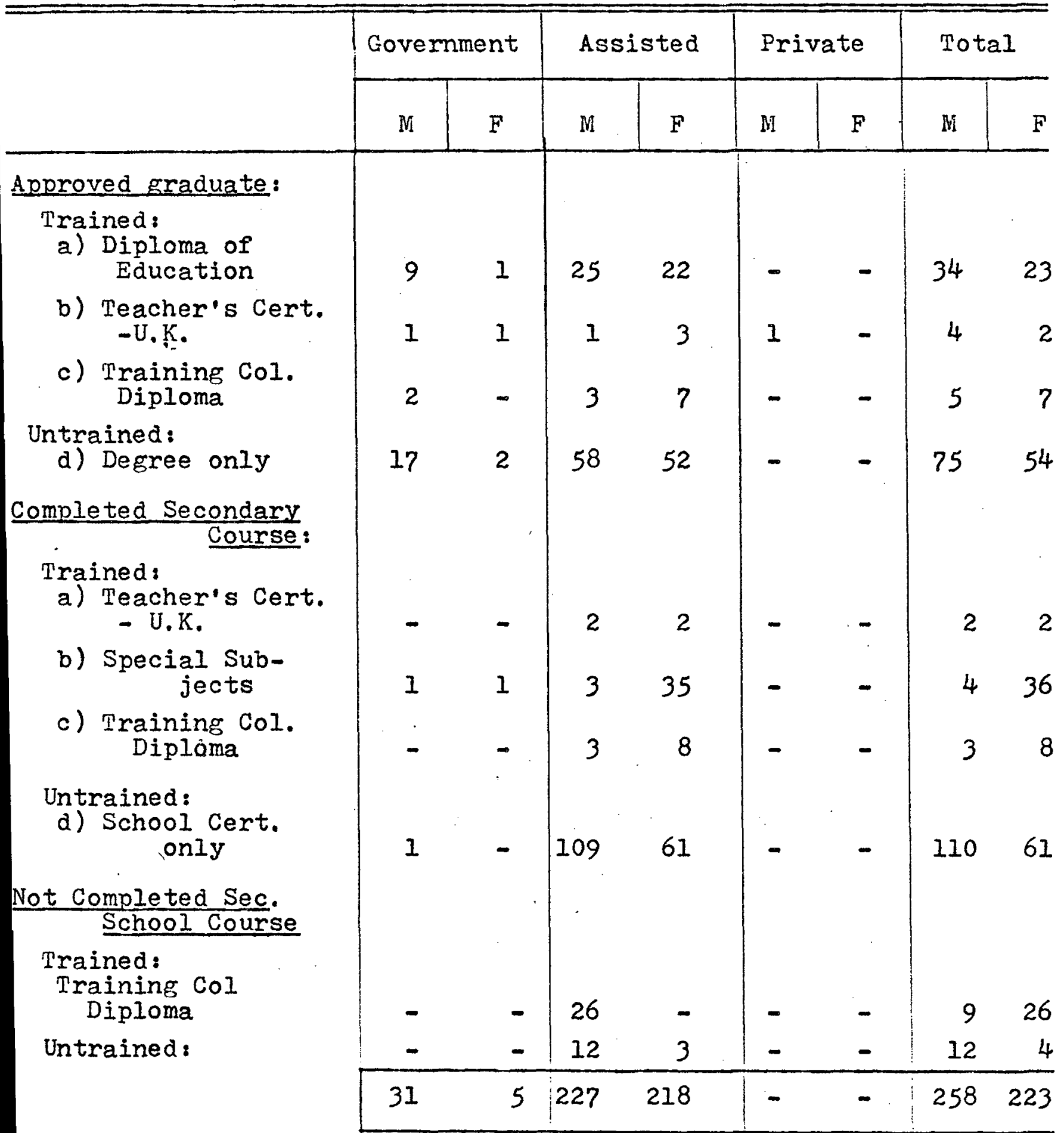

Source: Trinidad and Tobago Administration Report of Department of Education, 1958, p. 13. 
The Central School

The purpose of the recommended Central School was. in the Committee's view, not only for providing more meaningful post-primary education, but also to promote the socialization much needed for the integration of the community (Maurice, 1960, p. 50).

\section{Compulsory Education}

The Committee thought that, for a successful implementation of its proposals, proper use would have to be made of the resources provided, and that action should be taken to secure the attendance of pupils at the schools. They, therefore, suggested the extension of the compulsory school age from twelve to fifteen years of age (Ibid., p.52).

\section{Post-Secondary Education}

In the period preceeding the work of the Maurice Committee, provision of education had been limited to primary, secondary and scholarship levels. The one exception in Trinidad and Tobago was the College of Tropical Agriculture established in 1921, which had been offering nigher level courses in this field. Some few ambitious persons had taken hold of their courage and, by dint of hard work, had done correspondence courses and succeeded in passing the difficult external examinations of the University of London, and had achieved as much as a laster of Arts degree in classical studies.

To meet the need of post-secondary students, the 
Committee recommended the establishment of the following schools of formal education: (1) Polytechnic or Vocational Schools, (2) A senior technical college, (3) farm schools, (4) university extension centers or a college of liberal arts (Ibid., p. 53). A scheme of educational planning from nursery school to higher education was also presented.

\section{The Board of Industrial Training}

Technical and vocational education began in Trinidad in 1906, when the Board of Industrial Training was established "to arrange as far as possible for the technical education of artisans and apprentices (Trinidad and Tobago Independence Exhibition, 1962, p. 19)." Though the original classes consisting of about a dozen students were conducted only in typography, bookbinding, and tailoring, other trades were added through the years. At the time of the Maurice Committee, there were nearly 3,000 students, most of whom were taking part-time courses in 40 different trades at several centers in the country. There were also over 600 registered apprentices, including many from the oil companies. For the benefit of day-release apprentices, a peripatetic teacher was made available. The first full-time classes in technical subjects started with the opening of the Junior Technical School by the Board in San Fernando in 1943. Several oil companies also provided in-service training for their workers.

The govermment established its first technical 
institute at $\operatorname{San}$ Fernando, in 1954 with 70 students in a two-year pre-vocational course. This was later extended to a three-year and then to a five-year course leading to the General Certificate of Education of the Associated Examination Board.

The Maurice Committee had high commendation for the Board of Industrial Training and advised that the Department of Education should give serious study to assuming the duties of the Board as it had requested (Naurice. 1960, p. 55). It was through the services of the Board of Industrial Training that many of the country's youth were able to find a means of livelihood and fulfillment outside the narrow curriculum of the secondary schools.

\section{A Technical College}

The development of technology both within the country and in the outside world demanded that higher technical knowledge be made available. The Committee, therefore, advised the establishing of a senior technical college in addition to the proposed Polytechnic. This was more desirable since there was no faculty of engineering at the University College of the West Indies (Ibid., p. 56).

\section{Agricultural Education}

The Committee emphasized the imprtance in the life of the society of agricultural education, and advised that agriculture should be taught in the primary schools (where, however, the scope would be limited) as well as in the sec- 
ondary schools, especially in rural areas (Ibid., p. 59). Along with the Eastern Caribbean Institute of Agriculture and Forestry there has existed in Trinidad since 1960 the Faculty of Agriculture of the University of the West Indies. This Faculty was formerly the Imperial College of Tropical Agriculture.

The University of the West Indies

Though this study is not directly concerned with higher or university level education, a statement in this regard may be relevant here, since Trinidad and Tobago must look mainly to this institution to fulfill its needs of professional and administrative staff. The products of this institution will help to determine the accessibility of quality education for the youth of the country.

Founded by Royal Charter in 1949, the university came into being through assistance of Colonial Development and Welfare funds, as an affiliate of the University of Iondon. After thirteen years of consolidation and expansion, the University College became, in 1962, the autonomous University of the West Indies (U.W.I), offering its own degrees and carrying out its own programs of research. Its Faculty of Engineering was established in Trinidad, and the former Imperial College of Tropical Agriculture was merged with the University in 1960 to become its Faculty of Agriculture. With the aid of a liberal United States grant for construction of buildings, the Government of Trinidad and 
Tobago established, in 1963, a Iiberal Arts College, which became known as the John F. Kennedy College of Arts and Science of the U. W. I. (Trinidad and Tobago: The Making of a Nation, 1962, p. 42; Williams, 1969, p. 240). The Maurice Committee advised, in 1959, that the University College should extend its work and raise its standards so as to provide for the educational enlightenment of more of the people of the British West Indies.

Recommendations of the Maurice Committee

Following is a compendium of some of the recomendations of the Niaurice Committee pertinent to the development of secondary education:

1. That the College Exhibition be abolished owing to the unsatisfactory nature of its scope and questions.

2. That there be a common entrance examination for all secondary schools whether government or assisted.

3. That a new series of readers be produced reflecting West Indian culture and ideals.

4. That the intermediate schools be abolished and be reorganized as secondary modern schools.

5. That the normal type of school be the comprehensive, and that existing grammar schools be reorganized. 6. That steps be taken for the establishment of secondary schools for girls in Port-of-Spain and San Fernando.

7. That a large number of scholarships be offered 
in science and mathematics.

8. That the administration and inspection of all secondary schools be actually undertaken by the government.

9. That the regulations for awarding scholarships on the primary level be improved.

10. That secondary schools in rural areas be required to teach agriculture, and that graduates of the College of Tropical Agriculture be appointed for that purpose.

11. That secondary modern schools be established for pupils failing to obtain places in the grammar schools.

12. That secondary modern schools develop their own local pattern with four-year courses up to age sixteen.

13. That a uniform high school certificate be developed of sufficiently high standard to be acceptable both to government and local enterprise.

14. That all pupils in the secondary modern school be given a general education and do bilateral courses in academic and practical studies.

15. That foreign language be taught as a living language by teachers capable of conversing in the language. 16. That central secondary schools be established, especially in populous areas.

17. That secondary schools be free schools.

18. That the comprehensive type secondary school be located in new areas.

19. That the compulsory age for education be raised to fifteen years. 
20. That the following types of school be established:

a) Polytechnic

b) Senior Technical College

c) University extension center

d) College of Iiberal Arts

e) Farm Schools

21. That commercial education be treated as a vocational subject.

22. That a Senior Technical College be established, and courses in engineering, surveying, and architecture be given.

23. That all or some of the students at the College of Iiberal Arts be paid allowances or given scholarships.

24. That evening classes be conducted at the college.

25. That the status of the University College of the West Indies be changed to enable it to confer its own degrees.

26. That the University be constituted the examining body for final examinations of secondary schools.

27. That the minimum requirement for teachers shall be the grade 2 Cambridge School Certificate or the equivalent General Certificate of Education.

28. That an emergency training course be conducted as a temporary measure for teachers.

29. That the government build a central teachers' 
college to accommodate three hundred students who would serve in government and assisted schools.

30. That the curriculum for teachers' colleges be organized and made more effective, and new courses introduced in order to produce better prepared teachers.

31. That special teaching scholarships be provided.

32. That one-year and two-year special teachers' courses be given as are offered by the University of London (Maurice, 1960, pp. 177 to 196).

The Maurice Report was in effect the draft. of a design for educational planning for Trinidad and. Tobago. It had touched upon the great educational problems of the country and, incidentally, of most countries of the world, namely, provision of more school places and also an education more suited to the varying aptitudes and needs of the young people of a rapidly changing society in a rapidly changing world. Former commissions had been concerned mainly with the teaching of the three Rs, morals, health and industrial education obviously for the support of the mainly agricultural economy, and classical education for the children of the upper strata of the society. There was hardly any statement by expatriate commissioners of the possibility of a technological or industrial future for the West Indian islands which were normally supposed to be markets for overseas manufactured goods.

The experiences of World War II had created an awareness of the need for more local production and industry. 
Gooding (1961, p. 132) shares the view that the presence in the post-war period of United States bases in the country, the opportunities thus provided for improving the standard of living of the people, and the democratic manner of American life concurred to stimulate desires for change and greater opportunities for education.

\section{National Planning}

Following the recommendations of the Maurice Committee, the govemment proceeded to build several secondary Modern schools, well distributed over the country. In addition to constructing schools the government began to plan for "the national aims and aspirations." Free secondary education was intended to be "the cradle of the new nationalism of Trinidad and Tobago, assimilating all the different cutural stocks and racial strains in this society (Williams, 1969, p. 283)."

Government entered into negotiations with the denominations whereby each of the assisted secondary schools would reserve 80 percent of its annual intake for government exhibitioners. Several of the denominations also received government assistance for building extensions and renovations. As a consequence the number of free scholars increased to over 3,000 by the year 1961 (Williams, 1969. pp. 281-283).

\section{Free Secondary Education}

It was the studied policy of the new government 
from its very inception to remove the traditional discriminatory practices in educational opportunity that had been a heritage of the colonial past. This was a necessary measure if a nation was to be built on true democratic principles. The government's announcement in 1960 of its intention to make its secondary education program free, was declared by the Prime Minister to be "a drastic step forward in the direction of integration (Ibid., p. 282)." Free secondary education then, on the basis of a common qualifying examination was finally realized.

\section{Froblems of Selection}

Government had achieved the ideal of abolishing tuition fees from all schools receiving subventions from the State (Williams, 1968, p. 52). Laudable as these arrangements were they were not without their defects and limitations. A number of factors deserve consideration, since it has not yet been possible to eliminate selection on the basis of the Common Entrance Examination:

(1) liany thousands of young hopeful pupils study hard, but a very large number fail to obtain a place. Selection procedures, therefore, yearly produce a large number of frustrated children who may regard themselves as inferior or as failures.

(2) The entrance examination consists of achievement and intelligence tests. The results of these tests are now shown by research to be a function of the variable 
environment involving home background and influence, and not mere innate intelligence. The validity of selective and competitive examination scores is therefore to be questioned (Dyer, 1963, pp. 435-441).

(3) Often the curriculum is determined by the examination, and the purpose of the primary school is distorted. In the language of the Hadow Report (1931), "it is a cardinal principle that the examination should follow the curriculum and not determine it (p. 105)."

(4). Children not selected usually seek secondary education in a private school, if they have the means. Several private schools have been an asset to the country, but many are not staffed or equipped to do effective work.

(5) The late Dr. Andrew Camacho (1967) indicated, in a public lecture, that selection may sometimes be determined by the availability of school places in the locality where the child lives and by the choice of school made by the parent. The question of privilege is, therefore, not altogether removed from common entrance procedures.

The Norwood Report (194I) stated: "The time is past when such guidance and direction as teachers' need can be given by an external examination (Norwood, 1941 in Williams, 1968, p. 54)."

\section{Development Planning}

The building of a community on solid grounds called for planning on a national scale. The new government, there- 
fore, initiated its five-year development programs in 1958 with a view to achieving social and economic reconstruction. Included in the program were various projects such as

(1) providing adequate facilities for the basic education of children and adults.

(2) providing additional facilities for technical education,

(3) increasing the number of secondary school places and the number of awards of free tuition, as the first step towards the ultimate goal of free secondary education,

(4) providing scholarships at University level to persons with sufficient ability to qualify for the professions and for key posts in the government service, in order to implement the policy of filling posts in the Civil Service and private industry with suitable local candidates. Every effort was to be made in secondary education to amplify the curriculum of the secondary schools, and develop different types of secondary schools including the grammar school, the central school similar to the modern school of the United Kingdom, and the bilateral school with technical streams.

These projects entailed prodigious outlays in initial and recurrent expenditure. New schools were built and places provided at both primary and secondary levels. Further provision of schools was envisaged with facilities for teaching Home Economics and. Industrial Arts on a two 
shift basis. These "Senior Schools" were to be housed in selected primary and secondary schools to cater for the minds of pupils who had not been awarded a secondary school place on the basis of the Common Entrance Examination. Yet, a single, over-all coherent program seemed to be lacking. Recently built secondary modern schools were converted into five-year schools offering courses leading to the General Certificate of Education " 0 "-Level examination, and the proposed Senior Schools were to operate on a two-shift arrangement (Pierre, 1968).

\section{International Planning}

After much rethinking and discussion with the assistance of a UNESCO planning mission, it was decided to abandon these previous schemes in favor of a thoroughly integrated and comprehensive approach to the Junior Secondary School.

The UNESCO Educational Planning Mission requested by the Rt. Hon. Prime Minister had advised the forming of an Educational Planning Unit to continue the work of the country's Educational Development Plan. This planning unit began its work in July 1964, and was joined by a UNESCO consultant in Educational Planning and Administration in 1965, and again in 1966.

The Draft Plan 1968-1983

The outgrowth of this high level planning was the historic and comprehensive "Draft Plan for Educational 
Development of Trinidad and Tobago 1968-1983." The details of the proposals which the Draft Plan aims at implementing are presented in Chapter II of this study.

The premises on which this 15-year educational plan are constructed involved the following broad decisions (Draft Plan, 1968):

(1) The principle of provision of general education for all children up to age 14 in two stages, namely primary, followed by Junior Secondary, should be accepted;

(2) The principle of provision of specialized education and training for a selected entry at age 15 into academic and/or technical courses should be accepted;

(3) The selection of pupils at 11-plus should be eliminated as rapidly as the resources of the country would allow of the expansion of opportunities for admission to Junior Secondary Schools;

(4) Specialized training should be provided as far as possible for approximately 35 percent to 40 percent of the age group above 15 years, bearing in mind proposals for an education extension service for persons not attending a full time school;

(5) Efforts should be made to achieve a fully trained teaching service by the year 1975 or as early as possible within available resources;

(6) Facilities for middle and higher level technician training should be expanded;

(7) The Library services of the country should be reorganized to provide the following:-

(i) a National Library

(ii) a School's Library Service

(iii) a comprehensive Rural Iibrary Service

(iv) a school for library training.

(8) Adequate accommodation should be provided for the Archives and National Museum and a programme should be mapped out to effect improve- 
ment to the facilities offered by both these institutions.

(9) The Division of Culture should be reorganized to include its upgrading and expansion, and cultural Art Centres should be established;

(10) The administrative structure and processes at the Ministry of Education and Culture should be revised so as to ensure that the Ministry could cope with the burdens imposed upon it by developments and changes;

(11) The system of financing Education (in particular the grant of assistance to schools) and of budgeting for Education should be revised;

(12) The curricula and syllabus used in the Education System at all levels should be brought into line with modern trends and the needs of the country as a whole;

(13) The present system of internal organization of the schools should be revised with a view to securing more efficient use of resources and greater effectiveness of the educational programme;

(14) All extensions to the school system should be geographically distributed so as to equalize educational opportunities according to regions and so as to centralize and concentrate the more expensive higher educational facilities, including Teachers' Colleges;

(I5) An Educational Publication Branch should be established in the Ministry of Education and Culture for the purpose of publishing text books and reading material;

(16) An Educational Testing or Measurement service should be established for the purpose of constructing national tests for the new educational system;

(17) A vastly expanded Educational Broadcasting (Television) service for use in school educational programmes, as well as "out-of-school" educational programmes, should be established (p. 3 ).

Figure 3 shows the educational ladder of the developing system of education. 


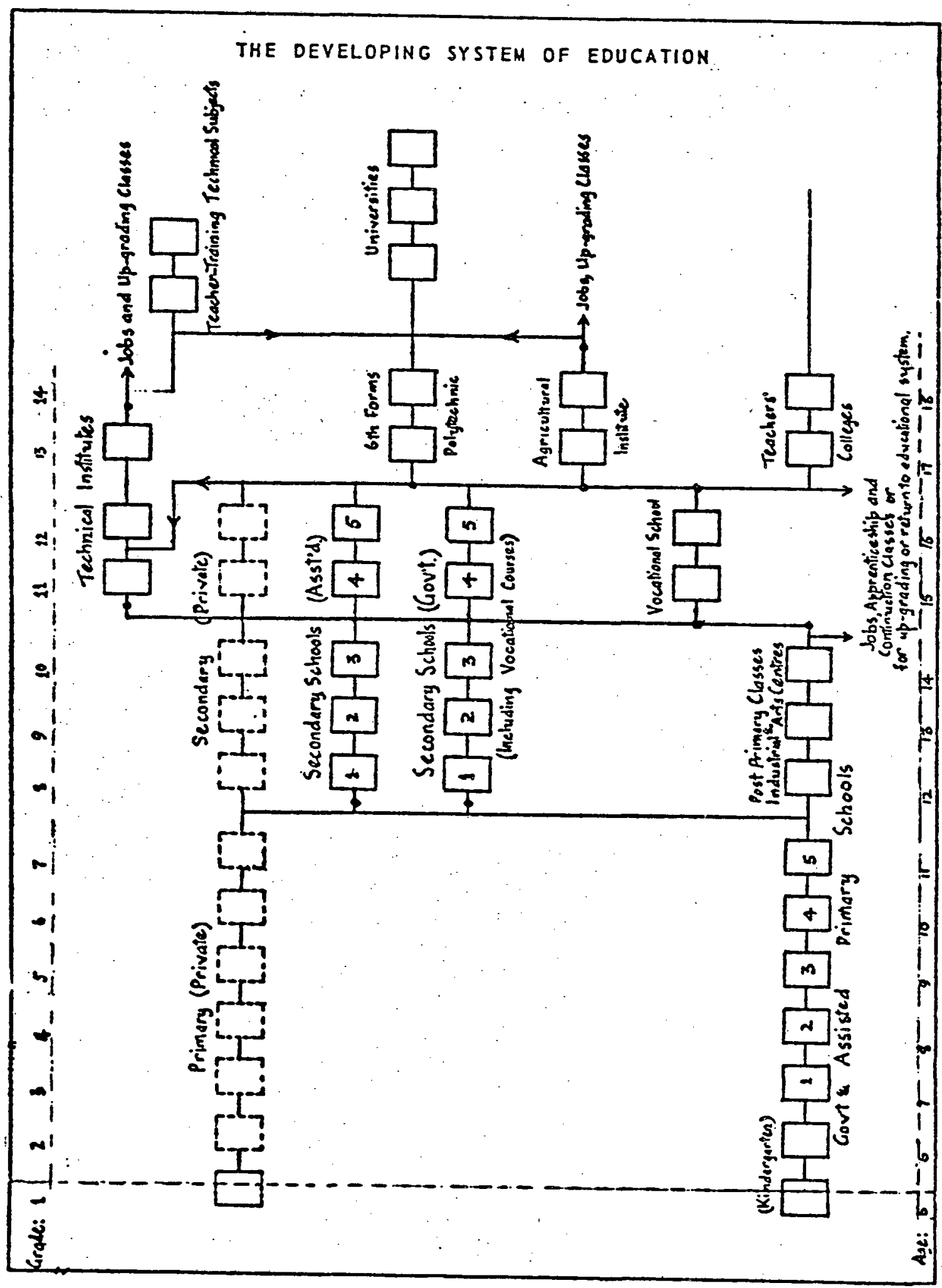

Figure 3.

Source: Draft Plan for Educational Development in Irinidad and Tobago 1968-1983. 
The Education Act 1966

A firm political base is necessary for any viable national system of education. The Prime Minister voiced this concept during the debate on the Education Act in December, 1965. The Act was "an attempt to establish a national system of education in independent Trinidad (Williams, 1965)." The principal objectives of the Act were (1) unification of the teaching service, thus removing the traditional discrimination against the primary school teacher, (2) the registration of all teachers, (3) the ban on discrimination against any child in any school on grounds of religious persuasion, race, social status, or language, (4) the placing of all teachers, including those in denominational secondary schools under the Public Service Commission, (5) the financial accountability of all assisted schools for government subventions.

\section{More Effective Government Control}

As has already been stated in this study the lioyne Commissioners had advised that "certain modifications regarding the details of denominational control are desirable in the interests of educational efficiency" and that it was proper for government to "assume more complete and effective control" of personnel of assisted denominational schools. Williams (1968) quotes the report of the Association of Directors and Secretaries for Education in England. The report regarded the demand for the abolishing of the dual system as not being a matter of the place of religious 
teaching in the schools but rather a question of "the imperative necessity of removing administrative dualism with all its harmful consequences (Ibid., pp. 55, 56)."

In Trinidad and Tobago, the government in the colonial period, had abandoned its right to educate almost entirely into the hands of the churches. The churches, it is true, did admirable work through their dedicated workers in maintaining education with govemment assistance. There was always, however, their proselyting interest, Though this promoted sectarian integration, it tended toward cultural separation.

Since the introduction of the Common Entrance selection, the denominational secondary schools had been extending their preparatory classes. In order to fill the 20 percent of school places allotted assisted secondary schools by the government for children of their own faith, some of these schools had been admitting over-age pupils from their preparatory schools. This was regarded by the Prime Minister as a scandalous use of public funds. He made it clear that even the allotted 20 percent was to be drawn from selected Common Entrance candidates (Williams, 1965).

The costs of modern education demand colossal sums of money which are becoming increasingly beyond the reach of the denominations. Government then has become the principal source of financing. The growing expenditure is even now beyond the resources of the country's budgets and ex- 
ternal and international sources have had to be tapped. It becomes more imperative, then, that a single educational authority be the directing agent.

In the colonial period, primary education was the responsibility of the director of education, secondary education the province of the College Council, and vocational education the function of a Board of Industrial Training. This lack of an integrated administration fostered the idea that one type of education was inferior and another superior. A single administration tends to promote a better articulation in the system and gives prestige to all types of education.

The bringing of the boards of assisted schools under the closer control of the Minister of Education and Culture by the Education Act 1966, seems to be a measure that will contribute to the integration that is necessary for achieving the national aims and purposes. Though very broad powers have been placed into the hands of the Minister, divided control and democratic functions can be maintained through the existing National Advisory Committee and Local Advisory Committees which the Act provides for.

The developing administrative structure is illustrated by Figure 4.

The Financing of Education

In 1938, when the Moyne Commissioners studied conditions in the West Indies they found that in some primary schools there was overcrowding when the schools were at- 


\section{STRUCT URE OF ADMINISTRATION OF EDUCATION}

\section{TRINIDAD AND TOBAGO}

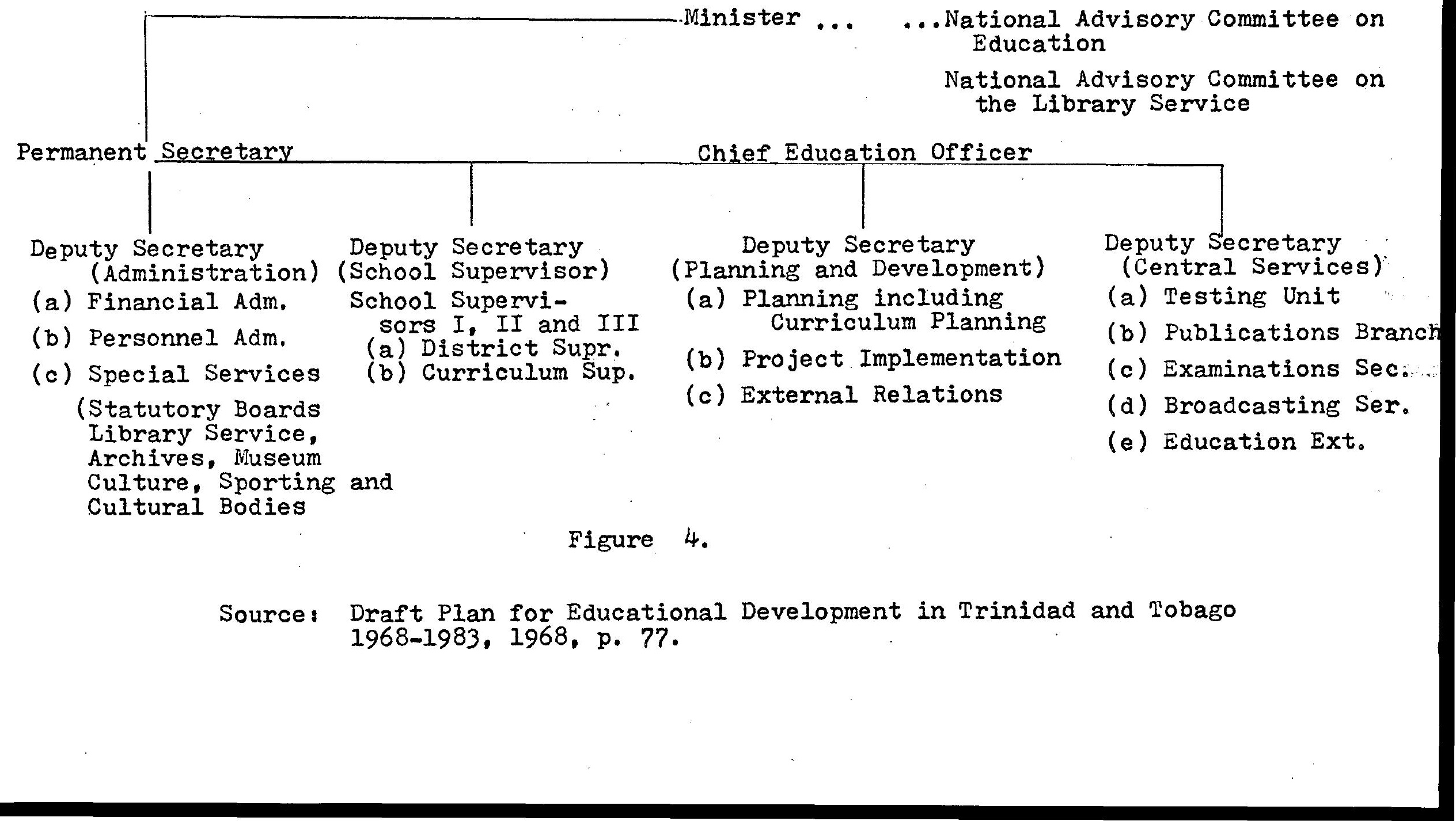


tended by only 50 percent to 60 percent of the school-age population. The schools were evidently inadequate in terms of buildings and teachers to accommodate all the children. The ratio of expenditure on education, too, was about one seventh that of England. The commissioners showed that even at this low cost, the provision of the same standard of education for even 95 percent of the children of primary school age would have been, beyond the financial capacity of the West Indian islands at that time or "at any time within the measurable future (Moyne, 1945, p. 98). In the light of this reasoning, the future for the more expensive secondary and technical education was not very hopeful. It is reasonable to conjecture that the presence of a corporate will or national outlook would have pointed the way to sharing the costs of education.

The principal means of public financing is direct taxation. Before World War II, in the West Indian island which had much lower standards of living, and were in desperate need of social services, the rate of direct taxation was several times lower than in England, where there were higher standards of living and much better social services (Williams, 1968, p. 122).

The revelation of the social and economic conditions in the West Indies by the Moyne Commission resulted in the Colonial Development and Welfare Act of 1945, which brought to Trinidad and Tobago 1 million toward its general development plan, and a total of $\mathbf{1 . 3 5}$ million by the year 1964 . 
as a result of subsequent Acts.

Much improvement in the public services resulted from this assistance, but allocations for primary and secondary schools did not keep pace with the growing demands and needs. The system of taxation has been greatly improved in post-colonial times so that local resources have been tapped, yet development projects in education have had to be carried out with the assistance of external aid, including technical assistance, loans and grants from Britain, Canada, and the U.S.A; the Ford Foundation, and international organizations such as United Nations, and the International Bank for Reconstruction and Development. Thus the rapidly changing middle years of the 20 th century found the country with inadequate resources for its greatly needed development.

In addition to its greatly improved local finances, Trinidad and Tobago now counts on external aid to realize its 15-year educational development project which calls for an expenditure of TT\$17I million, or an annual outlay of approximately $\$ 11$ million (Trinidad and Tobago: The Naking of a Nation, 1962, pp. 18-20; Hilliams, 1969, pp. 341-342; Draft Plan, 1968, pp. 97, 98).

In Chapter IV, mention was made of the interaction between economic development and education. This concept was brought home to the people of Jamaica by Professor Kandel (Kandel Report, 1943) in language that bears much significance for the people of Trinidad and Tobago: "Those who 
argue that those countries which have progressive systems of education can have them because they are wealthy, forget sometimes that they are wealthy because they are willing to incur higher expenditures for education ( $p, 22) . "$

Expenditure on the provision of educational facilities, then, must also be regarded as 'an investment in human resources."

\section{SUMMARY}

In 18th and early 19th century England, the then current ideas on education and the place of man in society were reflected in the relation of the State to popular education. Education was mainly a private affair. Various humanitarian and philanthropic persons and organizations were aware of the need to provide for the social uplift of the poor, and through their efforts succeeded in getting the State, by the year 1833, to acknowledge some responsibility.

This awareness was demonstrated in Trinidad, too, by the Imperial Negro Education Grant in the same year.

The missionary societies and the Mico Charity, with the aid of the Grant, established schools for moral and religious education and uplift of the ex-slaves.

Early governors were desirous of developing a system of education including post-primary education. The termination of the Negro Education Grant placed the responsibility for educational development in the hands of the government and the workers. 
Lord Harris later proposed his ambitious plan for national education in Trinidad, for he was much concerned about forming a society and not merely freeing a race. His advanced ideas were not consonant with the commercial demands of the plantation system, the laissez faire philosophy of the times, nor the sectarian proselyting interests of the denominations. His secular ward school system, therefore, declined after his departure.

The changes in the planters' fortunes, and religious and political interests seem to have determined the establishment of Catholic secondary schools.

The Queen's Collegiate School was established to counter the French-Gatholic influence in the British colony. The Catholic reply was the founding of the College of the Immaculate Conception and maintaining rivalry against the Royal College.

The Keenan Commission revealed the gross deficiencies and inequalities of the provisions for education, and made many recommendations, including the establishing: of university colleges in the West Indies. The dual system of control and financing of education was established, under which several secondary schools were constructed by the churches.

These denominational secondary schools were affiliated to the Queen's Royal College and shared in the arrangements for exhibitions to secondary schools and island scholarships for study abroad. 
Through social and economic factors access to secondary schools was barred to Negroes and East Indians.

With a view to improving the economy of the agricultural industry in the country, the Imperial Government endeavored to. stimulate more interest in agricultural education.

The two collegiate schools maintained high standards of classical education for the few and were very successful academically, but failed to meet the educational needs of the country as a whole.

Several expatriate commissions on different occasions studied the educational system in the country and in each case declared that the education provided at secondary level emphasized the literary field, and needed to be diversified and made more relevant to the country's needs. They also recommended improvements in the mode of supplying and training of teachers generally.

The need for a local university level institution was recognized as early as 1869, and was mentioned by more recent commissions, but was not realized until the mid-2oth century.

The dual Church-State system of control of education was effective since the mid-19th century, but, was not established until 1870. The churches played the dominant role in education for almost 100 years.

With the progress toward responsible government in the 1950s, there emerged an unusual national awareness. 
The country now looked inward for its direction in education, and set up the historic Committee on General Education, also known as the Maurice Committee, which investigated and made recommendations for every area of education in the country.

The work of the Maurice Committee was instrumental in initiating many far-reaching reforms in educational policy and practice.

The new government committed itself to the introducing of free secondary education. This was begun in 1961, within the limits of the country's resources, by giving free education to all pupils in government and assisted secondary schools on the basis of selection through a common entrance examination.

The resurgence of the interest in nationalism, the government's interest in educational development, the growing school population, all concurred to create demands for education as had never been seen before.

The extension of some of the faculties of the University of the West Indies to Trinidad and Tobago also enhanced the aspirations of the youth for higher education.

The government realized the need of more comprehensive and intensive educational planning, and with the assistance of UNESCO planning missions developed a 15-year Draft Plan for the Development of Education in Trinidad and Tobago.

In the interest of modern development of the organization of education for national integration, the need was 
seen for greater control by government of the administration of education. The Education Act 1966 placed very broad powers in the hands of the Minister of Education and Culture within the framework of a diluted dual system. All secondary and primary schools supported in whole or in part by government funds have now been constituted "public schools."

A large share of the country's annual budget is being allocated to education in order to finance its capital and recurrent expenditures; but the influence of its history, the rapid growth of population, and the contemporary social changes are creating demands which call for outlays beyond the national resources. Educational projects are being assisted by external aid. 
CHAPTER VII

\section{GENERAL SUMIMARY AND FINDTNGS}

\section{Review of Fundamental Problems}

The principal problems dealt with in this study are concerned with the determinants of accessibility of secondary education in Trinidad and Tobago. Among these, five major problems may be identified:

(1) the realization of equality of opportunity for the educational development of every child leaving the primary school

(2) the problem of financing education, which has been an important factor for a long time. Previous governments abdicated their responsibility for developing the country economically and socially, and the responsibility of the State for the education of all the country's youth. The new govermment regards the responsibility for education as a "national affair." This concept was signalled by the Committee on General Education (1959):

Not only is education a national affair and everybody's business, but the fact is, that a people cannot develop its own national pride and consciousness and grow to nationhood except by using education to mobilize all its human resources which are found available in all sections and classes of its populations ( $p p .24,25)$.

(3) the elimination of selection procedures. With 
its limited resources the government has undertaken the administration of secondary education and the provision of secondary schools. Selection methods used are undemocratic and are known to lack validity (Chauncey, 1965). In addition, there can be no selection without the corollary of rejection and the accompanying frustration of the thousands of rejects. The post-primary three-year cycle for pupils not selected has been found to be wasteful and is giving way to new junior secondary schools for the age-group 12 to 14+. Some of these schools have been constructed, but the accommodation is yet inadequate. The new schools, too, have already been criticized as postponing the bottleneck to age 14-plus years.

(4) Revision of curricula at both primary and secondary levels with emphasis on the needs and aptitudes of students, and the importance of orienting school programmes to the basic needs of the society.

(5) The training and retraining of a new breed of secondary school teachers professionally and academically equipped, and having regard for the values of the whole of the society.

\section{Major Findings}

This study was motivated by a desire to present the conditions of access to secondary education in Trinidad and Tobago during its history, and to try to discover the historical determinants of the lack of congruence between the provisions made for this level of education and the demand 
for it that has existed up to the present time. A further motive has been to make a contribution to the literature on educational development in the country in order to a) understand its educational limitations, b) assist in evaluating its educational achievements, c) suggest a practical approach to the much desired goals of equal opportunity in education, and national unity.

The investigator initially proposed the hypothesis that the principal determinant of inequality of opportunity in education was the absence of a community of interests Several assumptions were also advanced. The numerous samples of data presented show the hypothesis and assumptions to be true, but other factors were also contributory.

The major findings are:

1. The labor demands of the pre-emancipation and later plantation system brought to the country an unintegrated collection of various races and social classes who lacked common national aims.

2. By its ascriptions of race and class, and its competitive scholarships and exhibitions, the school system which developed in the colonial period tended to perpetuate distrust, jealousy, and a lack of a spirit of community.

3. The social conditions existing in Trinidad and Tobago up to the second World War did not provide the framework necessary for educational advancement. Educating laborers under slavery or under indenture was not consonant with the fundamental requirements of the plantation system. 
4. The continued low wages and squalid living conditions of the workers even into the 20th century were a reflection of the laissez faire philosophy of $18 \mathrm{th}$ and 19th century Europe.

5. In the late 1930s, the depressed social and economic conditions precipitated civil disturbances in Trinidad and other West Indian islands.

6. The Royal Commissions of 1937 and 1938 revealed that the low social and economic level at which Trinidad and Tobago was being maintained and administered could not provide the means for any adequate reform, and that it was necessary for the indigeneous people to play a greater part in the government and administration of their territory.

7. The reports of the commissions led the British Govermment to declare a policy of leading the colonies to self-government as quickly as possible.

8. In 1945, the year of the comprehensive Moyne Report, adult suffrage was granted to Trinidad and Tobago. 9. The constitutional changes led to the restructuring of the administration of education, and, as a consequence, education increased considerably during the 1950s.

10. The progress toward responsible government triggered a great increase in national sentiment, and in access to secondary education.

11. The economic interest in Trinidad and Tobago well into the 20 th century was mainly in large-scale production of crops, mainly sugarcane. Most planters were 
little concemed with the educational development of people who were expected to spend their lives in the limited occupations of plantation agriculture.

12. The British Parliament recognized the rapid improvement the ex-slaves had made after emancipation, in religious and general instruction, but saw that advancement of the laborers proved to be diastrous to the planters. The imperial interest was therefore turned to a new supply of immigrant labor.

13. Large sums of public finance were used to support immigration and indenture at a time when public services were badly needed.

14. An ambivalence is observed in the attitudes of both the Imperial Government and the Trinidad Governors. There was an evident desire on their part to provide for the education and uplift of the laborers, and at the same time to support legislation aimed at promoting the profitability of the plantation with low-cost labor. The greater concern of the legislature was consequently not with developing a society, but with the enterprise of sugar production.

15. The imperial attitude to the status of the laborers encouraged a continual state of dependence of the laborer upon the plantation, with a view to providing the labor force needed for the plantation economy.

16. The establishment of the Crown Colony in the early 19th century was predicated on the need to maintain 
political and economic stability, but the prolonged political stagnation which resulted from repeated refusals of the Imperial Government to grant representative government is viewed as an expedient of the metropolis to preserve certain advantages to itself.

17. The social adjustments and mores of the 19th century estates and plantations, and the arrangements for immigration and indenture have tended toward a high rate of population increase in Trinidad and Tobago. High death rates formerly helped to exercise some demographic control. However, the great improvement in health services in the 1930 s and 1940 s produced a reduction in death rates, and especially infant mortality rates, with a consequent rise in the teen-age population in the 1950s and 1960s. The rate of population growth in Trinidad and Tobago (Rubin \& Zavalioni, 1969, p. 192n) is considered to be among the world's highest.

18. The increased school-age population has necessitated large expenditures on educational provisions even beyond the country's resources. The consequent unemployment and under-employment will produce further difficulties in preparing the youth for living in their environment.

19. The greatest political changes in Trinidad and Tobago took place in the 1950s under the leadership of Dr. Eric Williams with his strategy of social and political education of the general public.

20. Cultural and religious factors in the society 
prevented East Indians, especially during the 19th century, from sending their children to school. The work of the Canadian Presbyterian Mission stimulated among them an interest in education.

21. The ultimate development of state interest in education in Trinidad and Tobago resulted from the ideas current in England in the 19th century.

22. The govermment and the Catholic classical schools established in the latter half of the 19th century grew out of the political and ideological rivalry of the period. The purpose of secondary education was therefore incoherent and unintegrated.

23. The secondary schools were provided especially for the upper class whites, so that Negroes and East Indians were socially and economically excluded.

24. The only channel of mobility for the lower classes were the few College Exhibitions and Island scholarships.

25. The classical nature of the curriculum of the secondary schools and the system of competitive exhibitions and scholarships caused the purposes of secondary education to be oriented toward the metropolis and away from the needs of Trinidad and Tobago.

26. Under the colonial government secondary education was almost entirely in the hands of the religious denominations and private individuals.

27. Since the 1950s, when the Crown Colony was on 
its way, out, secondary education has been viewed, in the light of the British Education Act 1944, as a stage in the general development of the pupil, and not as a special type of training.

28. Under the impulse of responsible government, the Committee on General Education in Trinidad and Tobago was set up, and with its strong emphasis on national purposes, was instrumental in charting the course of education into the new era of educational development in the country.

29. The resurgence of nationalism since responsible government and independence, the government's interest in promoting free secondary education, the rapidly increasing teen-age population, and the presence in Trinidad of some of the faculties of the University of the West Indies, all conspired to proclaim a loud imperative for secondary education which was beyond the resources of the country.

30. The historic Draft Plan was government's response to the demand for education.

31. The: implementation of the comprehensive Draft Plan with its need of partial external financing required the Ministry of Education and Culture to be freed from the restrictions of the old dual system. Broad powers have been provided by the Education Act 1966.

32. In the language of the Draft Plan (1968), "The constantly evolving economic, social and cultural needs of the nation contrast sharply with the almost static conditions of the past. National objectives in education are 


\section{0}

both more ambitious and more diverse (p. 79)." 
CHAPTER VIII

CONCLUSION AND RECOMMENDATIONS

The following conclusion and recommendations are presented in full recognition of the broad scope of education in time and place, as enunciated by Iord Harris over 100 years ago, and by the Trinidad and Tobago Working Party on Education in 1972. The roles of the home, the religious bodies, and the local community must always be recognized in the administration and organization of education.

\section{Conclusion}

1. The nineteenth century platonic concept of different roles for the various classes of society prevented the early development of a national system of primary and higher education.

2. The concept of State responsibility for universal education was not well supported in nineteenth century and early twentieth century in Trinidad.

3. The ambivalent attitude of the Imperial and local governments in regard to the interests of the planters and the education of the laborers finally led to a state of unprogressive dependence on the plantations.

4. The expressed intention of the planters was that Trinidad was to be developed by means of the large planta- 
tion, so that education of laborers' children was not compatible with the demands of an agricultural society.

5. Secondary education in Trinidad developed out of political and ideological conflict in an unintegrated society, and was originally intended to cater to the needs of the upper classes of the society.

6. The scant opportunites provided for access to secondary and higher education through competitive exhibitions and scholarships resulted in orienting the purposes of secondary education away from the pupils' environment and toward metropolis.

7. The strong denominational control of primary and secondary education encouraged ethnic and class cleavages. The sectionalism and sectarian interests which characterized church dominated education could not be supported in the new national purposes and strategy.

8. The long continuance of the Crown Colony predicated on the need for political and economic stability in the country resulted in the stunting of local initiative for the development of secondary education on a national scale.

9. The advance to responsible govermment in the 1950 s and the consequent passing of the Crown Colony resulted in a surging of national sentiment and general demand for secondary education.

10. The organizing of education at all levels for national integration demanded greater powers being placed 
in the hands of the Minister of Education and Culture through the Education Act 1966.

11. The social demands of the plantation economy and the great improvement in health conditions since the 1930 s produced an abnormally large number of teen-age youth in the 1950s and 1960s, when the country was moving toward independence.

12. The popular demand for secondary education relevant to the needs of the society requires financing for school buildings, teachers' colleges, and standard and technical equipment that are beyond the present resources of the country.

13. The generalizations deduced from the analyses of the foregoing chapters support the view that sectionalism and individualism have been the heritage of Trinidad and Tobago. The result was that the social and economic purposes of the country had not been directed toward building an integrated and educated community. Aspirations of the youth have been stimulated as never before; yet, the prized objective of secondary education for all, of equality with difference, has not yet been fully realized.

\section{Recommendations for Secondary Education}

Total Development

The content of the curriculum should be aimed at promoting the fullest personal development of every child leaving the primary school. 
Nethods of Inquiry

In view of the dynamic nature of life in the latter part of the twentieth century, of the explosion of knowledge, and the rapid rate of technological advance, which will require life-long education, the learning experiences of the pupils should include methods and tools of inquiry and research.

\section{Technical Education}

Technical education and vocational training should be provided within the framework of general education that aims at facilitating the mobility of the worker and the development of initiative.

\section{Student Centered Program}

The educational goals of a school and the curriculum planning objectives of an area of instruction should be selected with due regard to the goals, educational needs, interests, previous learnings, aspirations and self-perceptions of the student, and not in reference to traditional ideas and practices.

\section{Broader Concept of the School}

The school should be regarded as the center of learning for planning, organizing, administering and directing the formal learning program for its students; but the learning opportunities provided should extend to the home and the community agencies in order to involve the 
learners in community activities, work experience programs, self-directed study activities, surveys, research, field study, and study tours. To illustrate, (1) a girl in the home economics course may, with the help of her parents, prepare a family budget or design the furnishings layout for a room in the home, (2) a class in geography or social studies may, with the aid of maps, sketches, specimens, and artifacts, do a field study of a selected geographical area, a farm, or a manufacturing industry, according to the students' level of sophistication.

Community Involvement in Education

Community agencies and industrial concerns should view themselves more and more as forming a domain of the curriculum in the real world in which the student lives and for which he is preparing.

\section{Agricultural Education}

Pupils should be oriented early in their school career to the importance of agriculture for a West Indian country, and courses should be developed at all levels of learning. Such a program presupposes the availability of agricultural facilities in the students experience so that the teaching of agriculture may have reality.

Local Textbooks

Local textbooks should be prepared, and external ones modified, with a view to stressing wholesome human relations, sympathetic understanding of the various cul- 
tures, and the importance of national unity in the country. Study of English

Pupils should be impressed with the differences between standard English and creole English in regard to the appropriate areas and manner of usage. Students should be encouraged to make interesting and artistic insertions of native language in their written English compositions related to their environment. Often, expressions in Trinidad creole speech rightly classed as incorrect English are no more than quite correct French or Spanish transliterated into English--a result of the historical influence of these languages upon English, which was later imposed upon the minds of people whose mentality was already committed to the psychology of the romance languages. Many of these expressions should be regarded as an enrichment of Trinidad speech, rather than as "pidgin English."

Curricula for Man-power Needs

The curricula for secondary education should be adapted to the developmental needs of the nation in regard to man-power projections, anemployment and under-employment, and the brain drain. Programs in all secondary schools, including private schools, should be planned with reference to the man-power needs of the country.

\section{Student Appraisal}

Less emphasis should be placed on class grades or marks, and a comprehensive assessment should be made of the 
student's developmental needs, potentials, and talents, so that his individual program of schooling may be planned from entrance through secondary school. This researcher views this as being within the true concept of equality of opportunity.

Foreign Language

When a foreign language is included in the program of studies, it should be taught in a living manner by persons capable of conversing in the language. The content of the course should also bear much relation to the local scene.

\section{Student Decision-Making}

The traditional teacher-class interaction in instructional methods should be increasingly modified to promote student activity, including individual study, small group work, increasing student responsibility in planning and organizing individual programs, as well as lesson objectives and activities. Such a program, in the opinion of the researcher, would develop the decisionmaking ability of youth needed in the contemporary age.

Local Secondary School Leaving Certificates

Local or Caribbean School Leaving Certificates of equivalent value in academic, technical and agricultural fields should be developed in collaboration with the University of the West Indies. Certificates should also be issued at lower levels and should carry a respected value 
in the society.

School Counselor

Each public secondary school should be provided with a qualified staff member responsible for counseling, and working closely with individual students in planning, assisting, and assessing his educational development. This should be done whenever feasible in collaboration with the parent or guardian.

\section{Manual Occupation}

In order that all students may benefit from the economic and character values which result from manual occupation, every secondary school student should be encouraged to obtain some productive skill, practical art, or pre-occupational preparation.

\section{Community Solidarity}

With a view to developing a sense of community solidarity, legislation should be effected to require secondary school students receiving education at public expense to give a period of community service of some kind before proceeding to higher education.

\section{Sympathetic Staff}

All teachers and other staff members should regard it as their professional duty to demonstrate in every way that they are concerned about the emotional and physical well-being of every student under their care. 
Communication

In order that the government's educational plans may better serve the nation, a thorough program of information should be carried out in the interest of teachers, students, parents, and the general public, through the various communications media.

\section{Common Entrance Research}

A study should be done to determine the effects of selection procedures on both selected and rejected pupils. Some parents still refer proudiy to their selected child as "a Common Entrance scholar." It is also significant to know how deeply pupils are hurt by the frustration of rejection.

\section{Junior Secondary Research}

In view of the criticisms which have been made about the Junior Secondary School with its bottleneck at age 14t, a study should be done on the advantages of the Junior secondary over the basic school for ages (6-14 years) or (6-15 years). The Junior secondary School was criticized as far back as 1966, by the late Andrew Camacho, Vice-Dean, Faculty of Social Studies of the University of the West Indies; by the Trinidad Chamber of Commerce in 1968, and recently by Mr. Hamilton Maurice (Trinidad Guardian, April 29, 1974, p. 8), chairman of the famous Maurice Committee of 1959 . 


\section{Family Planning}

In view of the abnormally large child population of the country, the citizens of Trinidad and Tobago should be made aware of the importance of family planing to the social and economic development of the nation. The program of family planning introduced a few years ago should be pursued and receive the cooperation of the whole country, so that the rate of development of educational facilities may be able to keep pace with population growth. 
A P P EN D I C E S

251 


\section{APPENDIX A}

\section{The New Common Entrance Examination}

The tests are intended to assess those abilities that are known to be essential for successful secondary school work, and thus to identify the students having the highest probability of coping with secondary school requirements.

The examination comprises two sections: one is designed to measure scholastic aptitude or mental ability, the other, the level of achievement in three important skill areas. The mental ability tests, or what are commonly known as intelligence tests, give a measure of capacity for learning and adaptation. These tests assess the more general qualities of thinking--comprehension, level of concept development, reasoning, and grasping relations-qualities which seem to be acquired largely in the course of normal development without special in-school tuition. The aptitude section is made up of three tests. called verbal ability, numerical ability. and reasoning ability. Verbal ability is the ability to understand the meaning of words and of ideas expressed in words. A student whose verbal ability is high is likely to do well in English, the social sciences, foreign languages, or any other subjects that require the understanding of ideas expressed in words. In this test this ability is measured by means of a vocabulary test.

Numerical ability actually involves the ability to work with figures to solve simple number problems rapidly and accurately, and the ability to solve the mathematical problems through understanding of numerical processes and relationships. This ability is one of the best signs of intelligence and is closely related to success in secondary schools... It involves analysing a situation, seeing relationships, making generalizations, and drawing conclusions from any set of facts. 


\section{The Achievement Battery}

The achievement tests measure much more directly the outcome of specific in-school instruction. Tests are given in arithmetic, reading and English. Mastery of reading, arithmetic and language skills is generally regarded by staff of secondar y schools as extremely desirable, if not essential, for progress in secondary work.

The English test in the examination assesses the the ability to use the language correctly. Because of the limitation of time it is, unfortunately, restricted in its contents....

The new tests, moreover, do demand a higher achievement level. They are especially adapted to local conditions, e.g. in arithmetic the local currency is used in all questions involving money, and $t . s . d$. have been excluded. Words and phrases that have iittle significance in our environment have also been excluded. affair....

The examination is not, therefore a hit-and-miss

Tancoo, S. M. " "The Common Entrance Examination," The Educational Journal of Trinidad \& Tobago. Vol. I, No. 4, July, 1965, p. 2 . 


\section{APPENDIX B}

In support of abolishing the Common Entrance Examination, the following criticism was submitted in "Letters to the Editor," The Trinidad Guardian. October 12th, 1968:

The second point I would like to raise is the question as to whether the granting of free secondary education is an egalitarian measure and, therefore, assists in creating, in some sense, a more democratic social structure.

To argue, for example, that those who fall below the cut-off point can pay for their education in a private secondary school demonstrates the most inegalitarian part of the whole systiem.

\section{All studies in other parts of the world which} use a more or less similar system (e.g. Britain, France, U.S.S.R.) have demonstrated that those children who come from homes in the higher socioeconomic groups have a much greater chance of scoring high marks on the various selection tests (both objective and subjective), and therefore are more likely to be awarded free places.

Now, it is exactly the parents from these higher socio-economic classes who can afford to pay for their children's secondary education. In other words, by making this kind of education free, one is realiy only giving it free largely to those children whose parents used to pay.

To support my argument, I will quote from a study done in Guyana by Mr. M. K. Bacchus and published in "Social and Economic Studies" Harch 1966, on secondary school selection in which it was found that the children of farmers, skilled, semi-skilled and unskilled workers who make up the bulk of the population were awarded only 26.6 per cent of the free places in 1962 and 33.3 per cent in 1936.

The percentage of children from executive and professional class homes, a tiny percentage of the population, on the other hand were awarded 29.6 per cent in 1962 and 19.2 per cent in 1963. 
Comparative figures for Jamaica quoted in the paper showed the same mal-distribution. Children of farmers, skilled, semi-skilled, and unskilled workers in Jamaica in 1959 were awarded only 35.7 per cent of the places while they compose 68.2 per cent of the children who took the exam (of course they comprise a larger percentage of the total number of children in the population.

---Steve A. De Castro, lecturer at the University of the West Indies, St. Augustine, Irinidad. 


\section{APPENDIX C}

\section{How Valid are Selection Tests?}

It is now generally accepted that procedures of selection by achievement and intelligence tests in order. to determine who should be educated are lacking in validity.

President Henry Chauncey of the well-known Educational Testing Service at Princeton has affirmed that intelligence tests never really measured any innate thing that could be represented by an I.Q. score. What is tested is developed ability or aptitude. The unreality and inequity of placement by selective measures have mentioned by several educators and educational agencies (See Edmund J. King. Education and Social Change. New York: Pergamon Press, 1966, p. 67n.) 


\section{APPENDIX D}

\section{Colonial Administration of Trinidad in the Spanish Period}

\section{The Cabilido}

Under the system of political administration in the Spanish colonies, the city government was the only branch in which the residents of the colonies participated. This municipal corporation called the cabildo, or ayuntamiento, consisted of a body of councillors called regidores and one or more alcaldes or magistrates elected by the council (itunro, 1942, p. 9I). After the British conquest of Spanish Trinidad in 1797, the Cabildo of Port-of-Spain, which was a very prestigious body, was retained, since the Imperial Government found that the people at large were greatly attached to it, and regarded it "not without reason, as the constitutional guardian of some important popular privileges. - (Goderich to Grant, in Harlow and Madden, eds., 1953)!"

\section{The Audiencia}

Various means were provided in the Spanish colonies to discourage administrative misconduct. one of these was the audiencia, which was primarily a court of justice, but also functioned in political matters, and was presided over by the head of the Government. In the eighteenth century, Trinidad was administered by a govemor assisted by a cabildo, and the island came under the jurisdiction of the province of Venezuela (Williams, 1962, p. 15).

\section{The Residencia}

The viceroy of a Spanish colonial province held office nominally for a period of three years, later extended to five. At the expiration of his term of office, and before his departure, a public investigation of his conduct, called the residencia, was held by a judge especially appointed for the purpose (Munro, 1942, p. 86). 


\section{APPENDIX E}

\section{The Mico Charity}

In 1690, Lady Jane Mico of England had bequeathed a fortune to her nephew, Samuel, on the condition that he should marry one of his cousins. Failing this, the legacy was to be allocated to the redemption of Christians who had been captured by pirates of the Barbary countries. The young man Samuel failed to marry any of his cousins, and the Barbary pirates of the Mediterranean had been brought under control by the early 1800s. The abolitionists suggested that the legacy could be justly used for the purpose of Negro Education. This was granted, and the Mico Charity was organized to establish in the West Indies non-denominational elementary schools and normal schools for the training of indigeneous teachers (Gordon, 1963, pp. 23, 27, 28). 


\section{APPENDIX $\mathrm{F}$}

Exam. No. $1052 / 3$

\section{THE COLLEGE OF PRECEPTORS}

2 \& 3 ELOOMSSURY SQUARE, LONDON, W.C.I

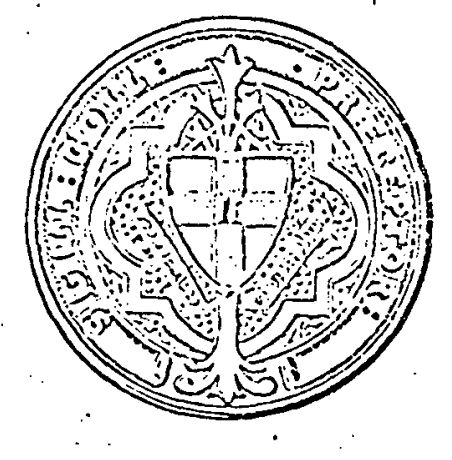

\section{STATEMENT}

This is to confirm that

\section{LIONEL IAWRENCE}

was a candidate at the A.C.P. Examination held in

$$
\text { August } 1968
$$

and satisfied the Examiners in the subject of

Educational Systems and

Their Development Since I900

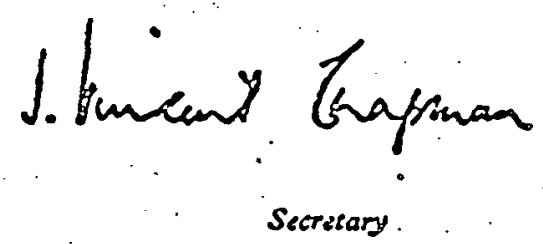




\section{BIBLIOGRAPHY}

Books

Augier, F. R., Gordon, S. C.., Hall, D. G., \& Record, in. The Miaking of the lest Indies. London: Longmans Caribbean, Ltd., 1964.

Augier, F. R. \& Gordon, Shirley C. Sources of West Indian History. London: Longmans Caribbean, 1962

Beckford, George I. Persistent Poverty: Underdevelopment in Plantation Economies of the Third Horld. New York: UxIord University Press, 1972.

Beckles, Iynn. "ilass Education Now Beyond Boards' Scope" in The Trinidad Guardian, December, 1965.

Brathwaite, Lloyd. The Develooment of Higher Education in the iest Indies. Social and Economic Studies, Vol. 7. No. I (Niarch 1958).

British Information Services. Trinidad and Tobago: The ilaking of a Nation. New York, 1962.

Burn, W. L. Emancipation and Apprenticeship in the West Indies. Iondon: Jonathan Cape, 1937 as cited in T. S. Simey, Welfare and Planning in the West Indies Oxford: The Clarendon Press, 1946.

The British West Indies. London: Hutchinson's University Iibrary. 1951.

Camacho, Andrew. "Education and Educational Opportunity," Chapter 7 in West Indian Social Problems, Malcolm Cross, ed., port-of-Spain, Trinidad: Columbus Publishers, Ltd., 1970.

Chauncey, Henry quoted in King, Edmund J. Educational and Social Change. New York: Pergamon Press, 1966; reprinted in 1969.

Cramer, John Francis \& Browne, George Stephenson. Contemporary Education: A Comparative Study of National Systems. New York: Harcourt, Brace \& World, Inc., 1956; reprinted, 1965. 
Curtis, S. J. \& Boultwood, M. E. A. An Introductory History of English Education Since 1800. London: University Tutorial Press, Ltd., 1966.

D'Aeth, H. R. X. Secondary Schools in the British Caribean: Aims and liethods. Iondon! Longmans, Green \& Co. , 1956.

De Verteuil, I. A. Trinidad, Its Geography, Natural Resources, Administration, Present Conditions and Future Prospects, second ed. London: Cassell, 1884.

Dyer, P. B. "The Effect of the Home on the School" in Social and Economic Studies, Vol. 17, No. 4 (Dec., 1968).

Gamble, The Reverend W. H. Trinidad, Historical and Descriptive: Being a Narrative of ivine Years Residence in the Island. London: Yeates \& Alexander, 1866.

Garcia, A. A History of the West Indies. Iondon: George Harrap \& Co. Itd., 1965.

Gooding, Nathaniel M. History of Education in Trinidad, .. an unpublished manuscript, ch. 3.

Gordon, Shirley C. A Century of Hest Indian Education; A Source Book. London: Longmans, Green \& Co. Ltd., 1963a.

- Reports and Repercussions in West Indian Education 1835-1933. London: Ginn \& Co. Itd., 1968.

- "Documents Which Have Guided Educational Policy in the West Indies-1ro.3," : Patrick Joseph Keenan's Report 1869 - Part 2, 'Secondary and Higher Education in Caribbean Quaterly, Vol. 9 Nos 1 \& 2 (1963b).

- "Documents Which Have Guided Educational Policy in the West Indies - No. 1," 'Rev. John Sterling's Report, May, 1835,' in Caribbean Quarterly, Vol. 8 No. 3 (Sept., 1962), pp. 145-153.

- "The Keenan Report 1869. Part 1: The Elementary School System in Trinidad' in Caribbean Quarterly Vol. 8, No. 4(December, 1962).

- "Documents Which Have Guided Educational Policy in the West Indies," Education Commission Report, Trinidad 1916, in Earibbean Quaterly, Vol. 10. No. 2 (June 1964). 
Gomes, Hon. Carlton, "Education" in Patterns of Progress, Roy Boyke, ed., Port of Spain, Trinidad: Key

Caribbean Publishers Trinidad, Itd., 1972.

Grant, K. J. Miy Missionary hiemories. Halifax, N. S. The Imperial Publishing Company, 1923.

Gt. Britain, Parliamentary Papers, 1810-1811 (184), Vol. $X I$, pp. 333-335, Lord Iiverpool to Governor Hislop, cited in Vincent Harlow \& Frederick Madden, eds. British Colonial Documents. Oxford: The Clarendon Press, 1953.

Gt. Britain, C. 0. 296/10, 1831, Goderich to Grant. Quoted in Vincent Harlow \& Frederick Madden, eds. British Colonial Documents. Oxford: The Clarendon Press, 1953.

Gt. Britain, Parliamentary Papers, 1847, XXXIX, 325, "Immigration of Laborers into the West India Colonies," p. 112, as cited by Donald Wood, Trinidad in Transition, p. 222. London: Oxford University Press, 1968.

Gt. Britain, C. 0., 295, Vol. 162, Iord Harris to Earl Grey, 1848, as cited in Thomas Spensley Simey. Welfare and Planning in the West Indies, p. 65. Oxford: Clarendon Press, 1946.

Hansard, Vol. 9, p. 789, July 13, 1807. Quoted in Nathaniel $\mathrm{i}$. Gooding. History of Education in Trinidad. unpublished manuscript, Ch. 3, pp. 3, 4.

Harlow, Vincent \& Madden, Frederick, eds. British Colonial Documents. Oxford: The Clarendon Press, 1953.

Kande I, I. I. The New Era in Education A Comparative Study. Cambridge, iviass : The Riverside Press, 1955.

Keathe, Governor to Secretary of State, 1857. Quoted in Shirley C. Gordon. A Century of West Indian Education, p. 75. Longmans, Green and Co. Ltd., 1963.

Keenan, Patrick. Keenan's Report on Education in Trinidad. cited in Donald Wood. Trinidad in Transition, pp. 225-235. New York: oxford University Press, 1968; cited in Shirley Gordon. A Century of iest Indian Education, passim; cited in Shirley Gordon. Reports and Repercussions in iest Indian Education p. 90. Ginn and Co.. Ltd., 1968; cited in Caribbean Quarterly, Vol. 9, Nos. I \& 2 (1963).

Lewis, Gordon K. The Growth of the Hodern West Indies. New York: Nodern Reader Paperbacks, 1968. 
Lowenthal, David. Hest Indian Societies. New York, Oxford University Press, 1972.

Haclure, J. Stuart. Educational Documents of England and viales 1816-1967. London: Chapman \& Hall, Ltd..: 1968.

Wlalik, Yogendra $k$. East Indians in Trinidad, A Study in Minority Politics. Lonaon: Oxford University Press, 1971.

Watheison, William Law. The Sugar Colonies and Lord Eyre 1849-1866. New York! Longmans, Green \& Co., 1936.

iuintz, Sidney $: V$. "The Caribbean as a Socio-cultural Area," Ch. 1, pp. 1-46, in Peoples and Cultures of the Caribbean. Michael iv. Horowitz, ed, New York: The ivatural history Press, 1971.

Wioister, William. Wiemorials of Missionary Labours in Western Africa, the West Indies, and the Cape of Good Hope. London: Williams Nichols, 46 Horton Square, 1866.

Morrell, W. P. British Colonial Policy in the Age of Russel and Peel. Oxford: Clarendon Press, 1930.

Munro, Dana Gardner. The Latin American Republics: A History. New York: D. Appleton-Century Co., 1942 .

Naipaul, V.S. The Middle Passage. London: Andre Deutsch, 1962.

Norwood, Sir Cyril. The Norwood Report 1941, as cited by W. 0. Lester Snith. Education, An Introductory Survey, p. 56. Middlesex, England, Penguin Books Ltd. . 1957.

ottley, Carlton Robert. The Story of Port-of-Spain. Port of Spain, Trinidad. The Author, 1962, p. 57. Quoted in Vera Rubin \& Marissa Zavalloni. We Vish to be Looked Upon, pp. 33, 34. New York: Teachers' College Press, 1969.

Oxaal, Ivar. Black Intellectuals Come to Power. Cambridge, Mass, Schenkman, 1968.

Parry, John Horace and Philip, iv. Sherlock: A Short History of the West Indies. New York: St. Wartin's Press, 1956.

Peterson, A. D. C. The Future of Education. London: The Cresset Press. Itd.,1968. 
Pierre, Fion. Donald. "Development and the 1968 Budget," in The Trinidad Guardian, April 1, 1968, p. 1.

Saylor, J. Galen and Alexander, Hilliam M. Plannine Curriculum for Schools. New York: Holt, Reinhart and Winston, Inc., 1974.

Sewell, William G. "The Crdeal of Free Labour in the Hifest Indies" Chapter 8 in Lambros Comitas and David Lowenthal eds. Slaves, Free iven, Citizens: West Indian Perspectives, New York: Anchor Press/Doubleday, 1973.

Sheffield, James R. Education in the Republic of Kenya. Washington, D.C.' U.S. Dept, of Health, Education and Velfare, 1971.

Simey, Thomas Spensley. Velfare and Planning in the West Indies. Oxford, Clarendon Press, 1946.

Southgate, George W. English Economic History. London: J. M. Dent and Sons, Itd., 1958.

UNESCO. Educational Planning. Paris: Place de Fontenoy, 75 Paris, 7,1970 .

Wardle, David. English Popular Education 1780-1270. Cambridge, The University Press, 1970.

Williams, Eric. Constitution Reform in Trinidad and Tobago: A Public Lecture. Port of Spain: Teachers Economic and Cultural Assn., Ltd., August 6, 1955.

- Education in the British West Indies. Port of Spain: Guardian Commericial Printery, 1951; reprinted, New York: University Place Book Shop, 1968 .

- Inward Hunger: The Education of a Prime lfinister. London: Andre Deutsch, 1969.

- History of the People of irinidad and Tobago. Port of Spain, Trinidad. P. N. il. Publishing Co. Ltd., 1962; reprinted, London: Deutsch, 1964. - Massa Day Done. Port of Spain, Trinidad: P.N.M. Publishing Co. Ltd., 1961.

- The Negro in the Caribbean: Bronze Booklet, No. 8. Washington, D.C.: Associates in Negro Folk Education, 1942 .

Wood, Donald. Trinidad in Transition. London: Oxford University Press, 1968. 
Official Documents, Reports and Journals

Gt. Britain. Board of Education. Report of the Consultative Committee on the Primary School, London: Fer Wajesty's Stationery Office, 1931; reprinted, 1962.

Gt. Britain. Ministry of Education Act 1944. London: $\mathrm{H}$. H. S. $0 ., 1945$.

- Report of a Commission appointed to consider Problems of Secondary and Primary Education in Trinidad, Barbados, Leeward Islands and Windward Islands, 1931-1932, Colonial No. 79. London: Fer iviajesty's Stationery Office, 1933. This Report is also known as the ilarriott-liaynew Report.

Report of Sir Frank Stockdale, K.C.ij.G., C.B.E. Development and Welfare in the West Indies 1943/44 Col. No. 189. London: Her Wajesty's Stationery Office, 1937.

- Trinidad and Tobago Disturbances 1937: Report of Commission. London: Her Ilajesty's Stationery office, 1937.

- West India Royal Commission Report. Cmd. 6607 Iondon: her Wajesty's Stationery Office, 1945.

Trinidad and Tobago. Administration Reports of the Education Department for the years, 1952, 1953, 1954, 1956, 1958. Port of Spain, Trinidad: The Government Printing office.

- Annual Administrative Reports of the Director of Education for 1945 and 1946 . Port of Spain, Trinidad: The Government Frinter.

Chaguaramas Education Conference: Education Working Party. Port of Spain, Trinidad, Government Printery, 1972 .

Central Statistical office, Annual Statistical Digest. Port of Spain: Government Printing iffice, 1970.

- Committee on General Education In Trinidad and Tobaro, Education Report 1959. Port of Spain, Trinidad: Guardian Commercial Printery, 1960. This report is also known as the Naurice Report.

- A Digest of Statistics on Education 1968-1969. Port of Spain, Trinidad: Central Statistical office 1973. 
Trinidad and Tobago. Draft Plan for Educational Development in Trinidad and Tobago 1968-1983. Port of Spain: The Government Printery, 1968.

- Education Act 1966. Port of Spain, Trinidad: Government Printery, 1966.

- Education Department Triennial Survey 1955-1957 and Annual Summary 1252. Port of Spain, Trinidad: Government Printery, 1959.

House of Representatives. Budget Speech of G. in. Chambers, winister of Finance and ininister of Planning and Development. Port of Spain, Trinidad: Government Printery, 1973.

- Independence Exhibition. Historical Development Education in Trinidad and Tobago 1800-1962. Port of Spain, Trinidad Government Printing Office, 1962 .

- Ministry of Education and Culture. The Educational Journal of Trinidad and Tobago vol. 1 . No. 4. Port of Spain, Trinidad: Caribbean Printers Itd.

- National Planning Commission. Draft Third FiveYear Plan 1969-1973. Port of Spain, Trinidad: Government Printery, 1968.

- National Task Force on Youth, Second Interim Report. Typescript, February 1973.

- Vorking Party on Education in Trinidad and Tobago. Report. Port of Spain! Government Printing office, 1954.

\section{Research}

Gooding, Nathaniel M. Education in Trinidad, Past and Present. Doctoral Dissertation, University of Connecticut, 1961.

Pujadas, Leo. "A Note on Education Development in Trinidad and Tobago 1956-1966." Trinidad and Tobago C.S.O. Research Papers, No. 6, $1969, \mathrm{pp}, 1-46$, Ref. pp. 29, 32. Cited in David Lowenthal, West Indian Societies. New York: Oxford University Press, 1972.

Roberts, G. W. "A Note on School Enrolment in Trinidad and Tobago 1960," Social and Economic Studies, 16(1967), pp. $113-126$. 
Rubin, Vera and Zavalloni, Marissa. We Wish to be Looked Upon: A Study of the Aspirations of Youth in a Developing Society. New York: Teachers" College Press, 1969.

\section{International Report}

Inter-American Committee on the Alliance for Progress (CIAP). Domestic Efiorts and the Need for Exernal Financing for Development of Trinidad and Tobago: Report No. IV. Wasnington, D.C.I Pan American Union, 1967.

Newspapers

"House Debates Education Act," The Trinidad Guardian, December 5. 1965. p. 3.

The Trinidad Guardian, September 17, 1967.

"The Demand for Secondary Education," The Sunday Guardian October 1, 1967.

Editorial, The Sunday Guardian, August 7, 1967.

Editorial, The Trinidad Guardian, Warch 5, 1967.

"Letters to the Editor," The Trinidad Guardian, October 12, 1968. 